\title{
How do warnings affect retail demand for Bitcoin? Evidence from an international survey experiment*
}

\author{
Axel Ebers ${ }^{\dagger}$ \\ Stephan L. Thomsen
}

March 2021

\begin{abstract}
Bitcoin is associated with different risks. We conduct an information experiment in the four largest European economies to analyze the effects of specific warnings and information on retail investors' demand for Bitcoin. Our results indicate that the impact is strongest when warnings point to privacy issues. Information on the lack of guarantees or on $\mathrm{CO}_{2}$ emissions only affects particular subgroups. Knowledge of broad public acceptance increases overall demand. Warnings can therefore effectively prevent extreme market events while avoiding the costs of stricter regulation. Effect heterogeneity implies that regulators should use specific information and different communication channels to reach relevant investors.
\end{abstract}

Keywords: Survey experiment, warnings, Bitcoin, retail demand, regulation, cultural differences JEL classification: C93, D83, G40

\footnotetext{
${ }^{*}$ We gratefully acknowledge financial support by the Deutsche Bundesbank. The views and opinions expressed are those of the authors and do not necessarily reflect the official policy of the funding institution. The experiment is registered at the American Economic Association (AEA) registry: "The effect of warnings on consumer attitudes towards cryptocurrency and central bank digital currency: A survey experiment" (AEARCTR-0006573).

$\uparrow$ Axel Ebers, Institute of Economic Policy, Leibniz Universität Hannover, Königsworther Platz 1, 30165 Hannover, E-Mail: ebers@wipol.uni-hannover.de, Phone: +49 (0)511 7624695

*Stephan L. Thomsen, Institute of Economic Policy, Leibniz Universität Hannover, Königsworther Platz 1, 30165 Hannover, E-Mail: thomsen@wipol.uni-hannover.de, Phone: +49 (0)511 76214596
} 


\section{Introduction}

Bitcoin $^{1}$ is the world's leading cryptocurrency that facilitates online payments based on encryption technology and a decentralized computer network. At its present all-time high on February 9, 2021, Bitcoin had reached a market capitalization of over $\$ 880$ billion with approximately 18.6 million tokens in circulation at a price of almost $\$ 48$ thousand each (Coinmarketcap, 2021). ${ }^{2}$ Bitcoin's public-private-key encryption provides a certain degree of privacy for users. The digital mining process allows the creation of new bitcoins without power concentrated among central banks. Payment settlement and validation through the decentralized network allow transactions without mutual trust, financial intermediaries, or legal rules for bookkeeping (Böhme et al., 2015).

However, privacy protection is limited despite encryption technology because investigators can use the payment history stored in the public Blockchain database to identify individual users (Reid \& Harrigan, 2013). For example, purchases from online retailers made with Bitcoin often reveal the buyers' real name and mailing address. Investigators could obtain the identity of a Bitcoin user from such a source and then trace back all transactions made with Bitcoin. In addition, strong economic forces push towards power concentrated among actors who have no legal mandate, such as currency exchanges, digital wallet services, or mining pools (Arnosti \& Weinberg, 2018). Most importantly, Bitcoin's design leads to distinctive risks that impede the cryptocurrency from serving as a medium of exchange or store of value. Market risk resulting from extreme price fluctuations, transaction risk due to irreversible payments, and counterparty risk from cyber-attacks on exchanges or digital wallets make it almost impossible for Bitcoin to fulfil the elementary money functions mentioned above (Yermack, 2015).

In 2020 alone, the price fluctuated between $\$ 5,200$ and $\$ 27,600$ before climbing to its so far alltime high at the beginning of 2021 (see Figure 1). Bitcoin to date is also inefficient, processing only seven transactions per second (Sedgwick, 2018), compared to Visa, which processes approximately 1,700 (Mechkaroska et al., 2018). In fact, analysis of transaction data suggests that people are using

\footnotetext{
${ }^{1}$ Following the computer science literature, we use the term "Bitcoin" with uppercase "B" to refer to the Bitcoin system. In comparison, we use the term "bitcoin" with lowercase "b" to refer to the actual Bitcoin tokens.

${ }^{2}$ The network processed approximately 360 thousand payment transactions that day (Blockchain.com, 2021). We retrieved the data on February 11, 2021. All key figures refer to this date.
} 
Bitcoin as a speculative investment rather than a medium of exchange (Baur et al., 2018). In addition to the described financial risks, investors must tolerate reputational risk because Bitcoin has facilitated illegal activities, including tax evasion, money laundering, drug trafficking, and prostitution (Foley et al., 2019; Marian, 2013). Nevertheless, an increasing number of institutional investors have started going into Bitcoin, with Tesla's \$1.5 billion purchase just recently offering the latest prominent example (Ostroff \& Elliot, 2021).

\section{$<$ Include Figure 1 about here $>$}

Although the overall risk for financial stability may be manageable under current market conditions, Bitcoin market development is dynamic, and links to the financial sector and real economy will likely strengthen in the future (Manaa et al., 2019). ${ }^{3}$ The need for regulation further arises from the motivation for investor protection. The risk of price collapse calls for disclosures to help retail investors understand the product. In addition to the regulatory options of prohibition or taxation, an official warning represents the lightest intervention in the market. Warnings may prove effective in preventing extreme price fluctuations while avoiding the costs of regulatory overkill. For example, if one country imposes too heavy a burden on Bitcoin services, they are likely to move elsewhere. Since Bitcoin is relatively stable in supply, warnings would have to change demand to have an effect on the price (Ma et al., 2018).

How can regulators design their warnings to be effective? Do people with different cultural backgrounds respond differently to these warnings? To answer these questions, we present the findings of a randomized survey experiment conducted on a sample of 2,223 people from the four largest economies in Europe: Germany, the United Kingdom, France, and Italy. The experiment investigates the impact of four different information treatments on retail investors' demand for Bitcoin. ${ }^{4}$ The information treatments contain three warnings that shock people's knowledge about 1) Bitcoin's lack of guarantees, 2) privacy issues, and 3) carbon dioxide $\left(\mathrm{CO}_{2}\right)$ emissions. In addition, treatment four informs

\footnotetext{
${ }^{3}$ Although the evidence of spillover effects of Bitcoin on other asset classes is mixed (e.g. Bouri et al., 2018; Trabelsi, 2018), financial markets are closely intertwined. If market capitalization further increases and the links to other financial markets become stronger, Bitcoin may pose a systematic risk in the future.

${ }^{4} \mathrm{We}$ focus on retail investors because institutional investors are only beginning to enter the market.
} 
people about growing public acceptance in the wake of the COVID-19 pandemic. We operationalize demand with the stated probability of buying bitcoins within the next 2 months.

Our first treatment closely resembles part of an official warning on lack of deposit guarantees and cyber-theft issued by the Joint Committee of the European Supervisory Authorities (2018). The treatment provides a good benchmark, as it shows the effects of an actual warning. The three other treatments relate to three major global trends. First, Bitcoin has received strong public interest for privacy protection by offering a high level of data minimization in online payments, i.e., processing adequate, relevant and limited personal data (European Parliament and European Council, 2016). Second, the increasing importance of sustainable investment conflicts with the $\mathrm{CO}_{2}$ emissions caused by the creation of new bitcoins (Mora et al., 2018). Finally, the lockdowns in reaction to the COVID-19 pandemic led to a fundamental change in people's behavior (van Bavel et al., 2020), accelerating the shift towards more online shopping (Sheth, 2020) and digital payments (Auer et al., 2020). This international study allows us to account for differences among countries in terms of financial culture, privacy concerns, environmental awareness, and the severity of the effect of the COVID-19 pandemic.

Our results show that the official warning has a negative effect on demand for the vast majority of persons as we expected. People who have already bought bitcoins, however, increase their demand in response to the official warning. This unexpected reaction mitigates the official warning's effect in the population. Notably, privacy considerations seem to be the most decisive factor in determining Bitcoin demand. The corresponding information treatment has the strongest and most robust effect. Ecological awareness triggers only selected persons implied from information on associated $\mathrm{CO}_{2}$ emissions that works in particular subgroups. Finally, knowledge of broad public acceptance raises demand across the population. These findings can help regulators design warnings that are more specific, and thus, more effective. At the same time, they offer useful implications for the design of central bank digital currency (CBDC). Currently, various central banks have developed cryptocurrencies to combine the benefits of Bitcoin with those of regulated legal tender (Bindseil, 2020).

This paper proceeds as follows: Section 2 outlines our research hypotheses and the corresponding information treatments in line with four global trends, data collection, a description of the sample, and 
balance checks are introduced in Section 3, and Section 4 presents our main findings along with a detailed analysis of effect heterogeneity across particular subgroups. The final Section provides our conclusions.

\section{Research Hypotheses and Information Treatments}

To investigate the causal effect of the differently framed warnings and information on retail demand for Bitcoin, we have developed four testable research hypotheses. These hypotheses form the basis of our information treatments, which provide a shock to people's knowledge about certain aspects of Bitcoin to push demand in a predefined direction. First, the first information treatment closely resembles part of an official warning issued by the Joint Committee of the European Supervisory Authorities (2018). The treatment points to the lack of deposit guarantees in the Bitcoin system and the associated risk of total loss in the case of cyber-theft. To reinforce the impact, the treatment informs participants that perpetrators stole $\$ 4$ billion worth of bitcoins in the first half of 2019 alone (Su, 2019). The official warning provides a good benchmark for the other treatments reflecting an actual real-world intervention. Since investors tend to be risk averse, we hypothesize that information on the lack of deposit guarantees and risk of total loss will depress their demand (hypothesis 1).

Our second information treatment provides a shock to people's knowledge about privacy issues in the Bitcoin system. The treatment informs people that, contrary to popular belief, Bitcoin is not completely anonymous. People can hide their identity by using a code number (the so-called public key) instead of their actual name for payment transactions. The Bitcoin system, however, stores each payment in the Blockchain database, which is publicly available. Investigators can use payment history and sophisticated analysis techniques to draw conclusions about the identity of individual Bitcoin users (Reid \& Harrigan, 2013). People value privacy because abuse of their personal data exposes them to costly practices, including spam, risk of identity theft, price discrimination in retail markets, or quantity discrimination in insurance and credit markets (Acquisti et al., 2016). We, therefore, hypothesize that information about privacy issues in the Bitcoin system will depress demand by investors (hypothesis 2). 
The third information treatment provides a shock to people's knowledge about the $\mathrm{CO}_{2}$ emissions caused by Bitcoin mining. To create a new bitcoin, miners have to solve a complex numerical puzzle, which requires enormous computing capacity. Large computer systems consume considerable electricity, which causes significant $\mathrm{CO}_{2}$ emissions and ultimately global warming (Mora et al., 2018). Against the background of global warming, sustainability criteria play an increasingly important role in investment decisions. In the United States, for example, the value of assets devoted to environmental, social, and corporate governance (ESG) investing increased by 42\% between 2018 and 2020 (Bisnoff, 2020). This increase also means a shift away from investments that pollute the environment. Accordingly, we hypothesize that knowledge about the $\mathrm{CO}_{2}$ emissions of Bitcoin will depress investor demand (hypothesis 3).

Finally, lockdowns in response to the COVID-19 pandemic have caused fundamental changes in people's behavior (van Bavel et al., 2020), which accelerated the shift towards online shopping (Sheth, 2020) and digital payments (Auer et al., 2020). We use this scenario to frame our fourth information treatment, which provides a shock to people's knowledge about the broad public acceptance of Bitcoin. The treatment emphasizes that even before the pandemic, $25 \%$ of the global population could imagine using Bitcoin. Following the literature on behavioral finance, investors tend to join the crowd in a rush to enter a market. This example of herd behavior is irrational and driven by emotion (Banerjee, 1992; Scharfstein \& Stein, 1990; Shiller, 2015). In fact, several studies suggest that herd behavior influences Bitcoin demand by investors (e.g. da Gama Silva et al., 2019). We, thus, hypothesize that information about the broad public acceptance of Bitcoin will push investor demand upward (hypothesis 4).

\section{Data Collection and Sample Description}

\subsection{Data Collection}

We collected survey data in the four largest economies in Europe, Germany, the United Kingdom (U.K.), France, and Italy, between October 9 and October 23, 2020. In each of the four countries, we drew a representative sample of the working population. The gross sample size was 610 in Germany, 635 in the United Kingdom, 616 in France, and 585 in Italy. Before providing the information 
treatments, we elicited people' knowledge about Bitcoin (elicitation stage). In particular, we asked them to estimate the share of the global population willing to use Bitcoin, the $\mathrm{CO}_{2}$ emissions caused by Bitcoin mining, and the value of bitcoins stolen in the first half of 2019. We randomly assigned people to the five treatment arms, i.e., the four information treatments (see Section 2 above) and a control group with no treatment, using a random number generator.

Then, we asked questions about Bitcoin demand. Following Manski (2004), we used the subjective probability of buying bitcoins within the next two months as our primary outcome because it reflects purchase intention and represents a good predictor of actual buying behavior. Our survey asked respondents to rate their probability of buying on an 11-point scale ranging from $0 \%$ ("no chance") to $100 \%$ ("certainly"). To analyze potential effect heterogeneity in subgroups of the population, we included questions about demographic characteristics, economic status, financial literacy, and experience with Bitcoin.

We conducted the surveys in the respective country language, i.e., in German, English, French and Italian (see Appendix B for the English version of the questionnaire). To avoid potential issues with cognitive dissonance, professional translation agencies provided translations to account for local culture and understanding. Data collection took place via LimeSurvey. A professional market research firm collected the data and ensured representative country samples. The setup of the data collection channeled respondents through screening questions, which ensured that the final sample was nationally representative with respect to age and gender (cross-quoted). The average completion time was approximately 6.30 minutes, and the median completion time was 5.30 minutes.

We checked the data carefully to ensure the validity of the results. In addition to an additional screening question, we identified speeders and straight liners. We assume speeding if a candidate's interview time was below one-third of the median interview time. Straight-liners give the same answer to every single choice question. If a candidate failed at least two of the three quality criteria (i.e., screening, speeding, or straight lining), the observation was excluded from the analysis. We also checked for outliers and implausible answers. After we cleaned the data, the total sample sizes were 526 for Germany, 642 for the United Kingdom, 529 for France, and 526 for Italy. 


\subsection{Summary Statistics}

Table 1 provides selected summary statistics of the covariates for the pooled and country samples. Demographic characteristics differ slightly between countries (e.g., age, academic degree, and employment status). More important for our research question are income differences, as they could explain differences in money demand. Italian participants earn the lowest incomes and French participants earn the highest incomes. ${ }^{5}$ German and British participants earn moderate incomes, with German participants earning slightly higher incomes. While Germany is home to slightly fewer top earners than the UK, the British middle class remains just as small as the Italian middle class. Furthermore, we use real estate ownership as a proxy for risk preferences and cash available for speculative investment. ${ }^{6}$ Italy is the frontrunner here, with four out of five Italian people owning real estate. In comparison, only one out of three German citizens owns real estate.

$<$ Include Table 1 about here $>$

In each of the countries surveyed, approximately one in ten had already used Bitcoin at least once, slightly less in France and slightly more in the other countries. This finding seems to reflect the growing dissemination of Bitcoin. A study from Germany, for example, showed that just under $4 \%$ of respondents had experience with Bitcoin in 2018 (Statista, 2019). The share has, thus, tripled. Finally, we observed differences in financial literacy, which tends to depress Bitcoin demand according to various studies (e.g. Huynh et al., 2020; Panos \& Karkkainen, 2020). German participants know the most about finance, and French participants and Italian participants know the least. The British participants know a moderate amount about finance.

\subsection{Checking for Balance}

Random assignment worked well in the experiment for all treatments and across countries. We checked for balance by separately regressing assignment to each of the four treatments on all of the

\footnotetext{
${ }^{5}$ Half of Italian people live on less than $€ 2,000$ euro per month. The same holds true for 4 out of 10 German and British people and only 3 out of 10 French people. On the other side of the spectrum, the proportion of French people earning more than $€ 4,000$ is twice as high as the proportion of Italian people.

${ }^{6}$ Investment in real estate could indicate risk aversion. At the same time, the investment ties up substantial capital, and thus, leaves little capital for speculative investments.
} 
covariates. The large share of insignificant covariates, the insignificant $F$-test on joint significance, and the close to zero adjusted coefficient of determination $\left(\operatorname{adj} . \mathrm{R}^{2}\right)$ indicate that the groups have the same characteristics on average (Table 2). Thus, no systematic selection into the groups occurred that could have biased our main results (i.e., no selection bias). We have also checked the balance for each covariate separately (see Table A.1 in Appendix A).

$<$ Include Table 2 about here $>$

\section{Empirical Findings}

\subsection{Main Results}

Figure 2 shows the main results of our four survey experiments for the pooled sample and by country. ${ }^{7}$ The subfigures plot the point estimates and $95 \%$ confidence intervals for the four different treatment indicators. The effects are estimates from linear probability models of the probability of buying bitcoins on the respective treatment indicator, country fixed effects, and a set of covariates. ${ }^{8}$ These covariates include age, age (squared), female sex, academic degree, employment, income (6 categories), financial literacy, Bitcoin experience, and the answers from the elicitation stage. We include these covariates to improve the statistical precision of the estimated treatment effects. For the final specification, we estimated a series of different models and chose the specification with the highest adjusted coefficient of determination for our analysis. Since we obtained data from a randomized experiment, the estimated treatment effects are quite robust across model specifications (Figure A.1 in Appendix A shows the results of different specifications applied to the pooled sample).

Our benchmark information treatment that resembled the official warning by the authorities had no significant effect on Bitcoin demand. The point estimates are negative, as expected, but lack statistical significance in the pooled and country samples. The results, thus, do not support our first hypothesis that information on the lack of deposit guarantees and risk of total loss would depress demand.

\footnotetext{
7 Tables with regression estimates of the empirical results in this and the following sections are given in the Appendix (Tables A.3 to A.26).

${ }^{8}$ We also assessed respondent's attitudes towards buying Bitcoin within the next two months, which correlates strongly with the probability of buying. Furthermore, we computed average standardized effects over the subjective probability of buying and consumer attitudes (Kling et al., 2007). The results are available upon request.
} 
Privacy, in contrast, seems to be the decisive factor in driving Bitcoin demand. Information about privacy issues lowers demand by 4.2 percentage points in the pooled sample. The result confirms our second research hypothesis. People seem to value privacy as it protects them from abuse of their personal data as described above. Bitcoin's developers, thus, initially conceived privacy protection, or at least data minimization, as a central feature of the cryptocurrency (Nakamoto, 2008). The value of privacy increases, however, when personal information implies a socially undesirable trait (Huberman et al., 2005). This situation, in turn, fits with the understanding that people often use Bitcoin for transactions they would rather conceal from society, such as drug purchases, tax evasion, or money laundering (Foley et al., 2019; Marian, 2013). There are also country differences. Italian people seem to have the strongest preference for privacy as they lower their demand by as much as 8.3 percentage points in response to the information. This finding is plausible, as Italian people also rank 28th out of 30 in terms of cashless payments in a European comparison (Malhotra et al., 2019). The point estimates from the other countries are close to the average effect but not significant.

Sustainability considerations only seem to play a negligible role in Bitcoin demand. While information about the $\mathrm{CO}_{2}$ emissions caused by mining new bitcoins reduces demand on average, all of the point estimates are insignificant. The figure shows a notable peculiarity. While people on the continent react as expected with lower demand when being informed about ecological damage, people in the U.K. react in exactly the opposite way and increase their demand. This finding is in line with studies finding significant country differences in ESG investing (Miralles-Quirós et al., 2019). In fact, companies in common law countries such as the U.K. tend to have lower corporate social responsibility (CSR) ratings than companies in civil law countries such as Germany, France, and Italy (Chih et al., 2010). Nevertheless, the results do not support our third hypothesis.

Finally, demand for bitcoin appears to be driven, at least in part, by herd behavior. Information on broad public acceptance increases demand by 2.9 percentage points. Even though the point estimate is only significant at the $10 \%$ level, the evidence is in favor of our last research hypothesis. We find a particularly pronounced effect in the U.K., where people increase demand by 6.6 percentage points (the 
effect is significant at the $5 \%$ level) based on broad public acceptance. The response to broad acceptance is lower and insignificant on the continent. Hence, British people seem to be more prone to herd behavior. Studies show that herd behavior is present in all developed stock markets (Chiang \& Zheng, 2010). Our findings imply that we cannot easily generalize these findings to other risky investments, such as Bitcoin.

\subsection{Effect Heterogeneity}

The analysis so far does not consider potential effect heterogeneity for different subgroups. Effect heterogeneity exists because differences in age, gender, and cognitive ability to understand the information will potentially influence Bitcoin demand. Figure 3 presents the estimated effects for selected demographic groups (age, gender, and education), with the pooled sample again as a reference. The low age group comprises the lowest tertile of the age distribution, and the high age group comprises the highest tertile.

$<$ Include Figure 3 about here $>$

The results indicate that understanding the official warning requires a high level of education and cognitive ability. It works only for academics and has almost no effect on non-academics. The same is true for young people. Gender differences are negligible. Education and cognitive ability also seem to play a major role in understanding the value of privacy. Information on privacy issues involved in Bitcoin works best with academics. The only other demographic group responding to this kind of offered information as expected is men. This finding contradicts a study finding that privacy protection in the online environment is of greater concern to women (Hoy \& Milne, 2010).

Notably, men are also the only demographic group to lower demand due to the high $\mathrm{CO}_{2}$ emissions from Bitcoin mining. This finding could indicate that they pay more attention to sustainability criteria in their investment decisions. However, women dominate the field of ESG investing (Marsh, 2020). We may also explain the result by the fact that men underestimate emissions more often than women in the elicitation questions. The treatment, thus, provided a shock to their knowledge about emissions more than it did for women. However, we must consider this conclusion cautiously, as the 
answers given in the elicitation stage had no significant effect on the outcome. Age and education do not seem to have played a role in ESG investing. Finally, only the elderly were prone to herd behavior. Information on broad public acceptance increases Bitcoin demand only in the top third of the age distribution. However, the elderly are also more likely to underestimate public acceptance than their younger reference group in the elicitation questions. Therefore, they experience a greater shock to their knowledge on public acceptance.

\section{$<$ Include Figure 4 about here $>$}

Figure 4 presents the estimated effects for subgroups according to different indicators of financial status. The subgroups of low and high income and low and high financial literacy refer to the lower and upper tertiles of the respective distributions. Similar to education in general, differences in financial literacy and experiences with financial assets (approximated by real estate ownership and income) are very likely to influence Bitcoin demand. The presented results confirm the claim made above that the official warning imposes high intellectual requirements on recipients.

The official warning only exerts the expected effect on people with high financial literacy. People with low financial literacy even tend to increase their demand, even though this effect is not significant. The results further show that wealthy people value privacy in their financial transactions. Information on privacy issues in the Bitcoin system has the expected negative effect across all subgroups with high financial status. People in the top third of the income distribution and those who own real estate lower their demand when they become aware of privacy issues. This finding may indicate that wealthy people are especially sensitive to the costs of discriminatory practices based on personal data. ${ }^{9}$ However, it may also reflect that wealthy people are more likely to make transactions they want to conceal from society. In fact, there is strong evidence that offshore tax evasion is highly concentrated in this group (Alstadsæter et al., 2019). Moreover, understanding privacy issues seems to require a great deal of

\footnotetext{
${ }^{9}$ The wealthy may be subject to negative price discrimination in online retail markets. Online retailers could offer them higher prices if they know about their high income and higher willingness to pay that may be associated with it. In contrast, the wealthy may benefit from positive quantity discrimination in credit and insurance markets. Wealth improves creditworthiness and access to loans. At the same time, wealth accompanies better health improving access to health insurance, for example.
} 
experience in managing finances. People with high financial literacy lower their demand due to privacy issues, whereas for those with low financial literacy, the effect completely disappears.

Information on $\mathrm{CO}_{2}$ emissions has no significant effect in any of the subgroups. Even though the effect is nonsignificant, people with low incomes and little financial knowledge tend to increase their demand in response to the information, which contradicts our expectations. Perhaps they are inexperienced in managing finances, and therefore, never encounter the idea of sustainable investing. Finally, people with low financial literacy are also most prone to herd behavior, which is not the case for people with high financial literacy. These results contradict the postulates of behavioral economics that cognitive biases are hardwired in the brain and cannot be compensated by financial education (Altman, 2012). We find it plausible, however, that people who have had a solid financial education are also aware of their cognitive biases and, thus, can consciously counteract them.

We further looked at differences between people who had already bought bitcoins before and those who had no such experience (Figure A.2 in Appendix A). Contrary to our expectations, Bitcoin buyers significantly increase their demand in response to the official warning. In line with the expected effect, information on broad public acceptance increases their demand. The other two treatments have no significant effect in this subgroup. However, these results should be considered cautiously since Bitcoin buyers are a select group, and we can only speculate about the reasons for their behavioral responses. The group is also relatively small, accounting for only approximately one-tenth of the total sample, which is reflected in the large standard errors. Moreover, the group has a much higher baseline, which could indicate level effects. Looking at the less selective group of nonbuyers indicates that the official warning may be more effective than implied by the main result above. In this group, the official warning has the expected negative effect on demand, even though it is only significant at the $10 \%$ level. The unexpected reaction in the group of buyers could, thus, have diluted the overall effect of the warning. The inexperienced also react as expected to information about privacy issues. The other two treatments have no significant effect.

Finally, Figure 5 shows the estimated effects for subgroups that we formed based on responses to the elicitation questions. To form the subgroups, we placed a 33.3\% band around each of the true values. 
Answers that lie within the $33.3 \%$ band belong to the "best estimates" group. Answers above this band belong to the "overestimates" group, and answers below this band belong to the "underestimates" group (Table A.2 in Appendix A shows the distribution of the subgroups).

$<$ Include Figure 5 about here $>$

The response to the official warning is insensitive to the prior knowledge that we have elicited. ${ }^{10}$ However, the treatment effects show an interesting pattern (although invariably insignificant): people who overestimate the public acceptance of Bitcoin react contrary to our expectations and even increase their demand in response to the official warning. We speculate that herd behavior blinds people to objective criticism. Overestimating the importance of Bitcoin apparently leads people to tune out privacy concerns as well. Information on privacy issues has the expected effect for people who underestimate public acceptance or emissions and those who provide the best estimates for emissions or the extent of theft. In other words, overestimation in any of the three categories implies an ambiguous effect of the information treatments considered.

Information about $\mathrm{CO}_{2}$ emissions works if people underestimate the actual importance of Bitcoin and the extent of emissions. The treatment effect is negative, as expected, and highly significant (1\%) if people underestimate any of the three elicitation questions. Notably, if people provide the best estimate for $\mathrm{CO}_{2}$ emissions, the effect not only loses significance but also disappears completely. The results regarding the final treatment contradict the hypothesis of herd behavior. Accordingly, people who previously underestimated the importance of Bitcoin would increase their demand when learning about broad public acceptance. Our results show the opposite picture: the treatment has the expected positive demand effect only for people who overestimate the importance of Bitcoin. Therefore, perhaps it is not just broad public acceptance but also information about sustained behavior change in the wake of the COVID-19 pandemic that has caused the treatment effect. This finding, in turn, could indicate that people are starting to perceive Bitcoin as a (potential) means of payment rather than a purely speculative investment.

\footnotetext{
${ }^{10}$ Hence, prior knowledge cannot explain the unexpected response of Bitcoin buyers shown in Figure A.2 in Appendix A.
} 


\section{Conclusion}

The results of our international survey experiment generally show that warnings have a significant impact on retail demand for Bitcoin and, thus, represent an effective tool for regulation. As a benchmark, the official warning lowers demand of people who have no prior experience with Bitcoin and represent the vast majority in the sample. This finding indicates that existing regulation works. The unexpected response of Bitcoin buyers appears to have diluted the official warning's effect, making it insignificant in the total sample. Nevertheless, our results indicate that there is room for improvement. Instead of pointing out the financial risks due to the lack of deposit insurance, authorities should focus on privacy issues, which seem to be the most decisive factor in determining Bitcoin demand. The great importance of privacy in digital payments is consistent with the high level of public interest in the topic, which has manifested not least in the European General Data Protection Regulation (European Parliament and European Council, 2016). Whether the strong preference for privacy protection among the wealthy arises from a higher sensitivity to discrimination in online retail markets or a penchant for offshore tax evasion remains an open question for further research. Given the immense economic damage from tax evasion, however, this question is of crucial importance. ${ }^{11}$

Information on $\mathrm{CO}_{2}$ emissions, such as the official warning, only has the desired effect in a subgroup of the population. This group, however, is different from the one responding to official warnings, as it includes people who underestimate the importance of Bitcoin, and thus, seem to be inexperienced with the subject. Men are overrepresented in this group. Another decisive factor in determining Bitcoin demand is broad public acceptance. Although we find evidence of herd behavior, which seems plausible given the hype surrounding Bitcoin, our results also allow for another interpretation. Namely, the accelerated shift to digital payments in the wake of the COVID-19 pandemic may have led people to perceive Bitcoin as an alternative means of payment rather than a speculative investment - at least potentially for the medium- to long-term future. Given the great potential of online

\footnotetext{
${ }^{11}$ For example, the estimated offshore wealth in the European Union was $€ 1.5$ trillion or $9.7 \%$ of GDP in 2016. The estimated revenue loss was $€ 36$ billion or $0.32 \%$ of GDP (Case, 2019).
} 
payments, especially in connection with the Internet of Things (Fernández-Caramés \& Fraga-Lamas, 2018), central banks have started launching their own cryptocurrencies (Bindseil, 2020).

The different effects of the warnings on different groups imply that regulators should address different target groups with specific content. While information on privacy issues and broad public acceptance works for the general population, information on deposit guarantees is better suited for experienced investors. Information on $\mathrm{CO}_{2}$ emissions, in contrast, suits investors who are rather new and inexperienced in the field of cryptocurrencies. Regulators should use the appropriate communication channels for targeting, where the relevant social media platforms can certainly be helpful. Our results also have important implications for the design of central bank digital currency (CBDC). Indeed, when central banks design their own cryptocurrencies, they should ensure privacy protection without opening the door for tax evasion. At the same time, they should ensure broad acceptance among the population at an early stage, such as by involving various stakeholders in the development process. Given the increasing importance and high volatility of Bitcoin and other cryptocurrencies, authorities should seek effective regulation while preventing regulatory overkill. In our study, we have shown how they can design warnings to work across socioeconomic groups and cultural differences.

\section{References}

Acquisti, A., Taylor, C., \& Wagman, L. (2016). The economics of privacy. Journal of Economic Literature, 54(2), 442-492.

Alstadsæter, A., Johannesen, N., \& Zucman, G. (2019). Tax evasion and inequality. American Economic Review, 109(6), 2073-2103.

Altman, M. (2012). Implications of behavioural economics for financial literacy and public policy. The Journal of Socio-Economics, 41(5), 677-690.

Arnosti, N., \& Weinberg, S. M. (2018). Bitcoin: A natural oligopoly. ArXiv Preprint: 1811.08572. https://arxiv.org/pdf/1811.08572.pdf

Auer, R., Cornelli, G., \& Frost, J. (2020). Covid-19, cash, and the future of payments (BIS Bulletin No. 3). Bank for International Settlements (BIS). https://www.bis.org/publ/bisbull03.pdf

Banerjee, A. V. (1992). A simple model of herd behavior. The Quarterly Journal of Economics, 107(3), 797-817.

Baur, D. G., Hong, K., \& Lee, A. D. (2018). Bitcoin: Medium of exchange or speculative assets? Journal of International Financial Markets, Institutions and Money, 54, 177-189.

Bindseil, U. (2020). Tiered CBDC and the financial system (ECB Working Paper No. 2351). European Central Bank. https://papers.ssrn.com/sol3/papers.cfm?abstract_id $=3513422$

Bisnoff, J. (2020). Why Socially Responsible Investing Is Likely To Gain Momentum Under Biden. 
Forbes Magazine. https://www.forbes.com/sites/jasonbisnoff/2020/12/14/esg-investing-asizzling-sector-that-will-get-even--hotter-under-president-biden/

Böhme, R., Christin, N., Edelman, B., \& Moore, T. (2015). Bitcoin: Economics, technology, and governance. Journal of Economic Perspectives, 29(2), 213-238.

Bouri, E., Das, M., Gupta, R., \& Roubaud, D. (2018). Spillovers between Bitcoin and other assets during bear and bull markets. Applied Economics, 50(55), 5935-5949. https://doi.org/10.1080/00036846.2018.1488075

Case, E. (2019). Estimating International Tax Evasion by Individuals. Taxation Papers No. 76, Directorate General Taxation and Customs Union, European Commission, https://ec.europa.eu/taxation_customs/sites/taxation/files/2019-taxation-papers-76.pdf.

Chiang, T. C., \& Zheng, D. (2010). An empirical analysis of herd behavior in global stock markets. Journal of Banking \& Finance, 34(8), 1911-1921.

Chih, H.-L., Chih, H.-H., \& Chen, T.-Y. (2010). On the determinants of corporate social responsibility: International evidence on the financial industry. Journal of Business Ethics, 93(1), 115-135.

Coinmarketcap. (2021). Bitcoin charts. https://coinmarketcap.com/currencies/bitcoin/

da Gama Silva, P. V. J., Klotzle, M. C., Pinto, A. C. F., \& Gomes, L. L. (2019). Herding behavior and contagion in the cryptocurrency market. Journal of Behavioral and Experimental Finance, 22, $41-50$.

European Parliament and European Council. (2016). General Data Protection Regulation. Official Journal, L119 (59), 1-88. https://eur-lex.europa.eu/legalcontent/EN/TXT/PDF/?uri=OJ:L:2016:119:FULL

Fernández-Caramés, T. M., \& Fraga-Lamas, P. (2018). A Review on the Use of Blockchain for the Internet of Things. IEEE Access, 6, 32979-33001. https://ieeexplore.ieee.org/stamp/stamp.jsp?tp=\&arnumber $=8370027$

Foley, S., Karlsen, J. R., \& Putniņš, T. J. (2019). Sex, drugs, and bitcoin: How much illegal activity is financed through cryptocurrencies? The Review of Financial Studies, 32(5), 1798-1853.

Hoy, M. G., \& Milne, G. (2010). Gender differences in privacy-related measures for young adult Facebook users. Journal of Interactive Advertising, 10(2), 28-45.

Huberman, B. A., Adar, E., \& Fine, L. R. (2005). Valuating privacy. IEEE Security \& Privacy Magazine, 3(5), 22-25. https://www.researchgate.net/publication/3437731_Valuating_Privacy

Huynh, K., Henry, C., Nicholls, G., \& Nicholson, M. (2020). Benchmarking Bitcoin Adoption in Canada: Awareness, Ownership and Usage in 2018. Ledger, 5.

Joint Committee of the European Supervisory Authorities. (2018). Joint ESAs Warning on Virtual Currencies. https://eba.europa.eu/esas-warn-consumers-of-risks-in-buying-virtual-currencies

Kling, J. R., Liebman, J. B., \& Katz, L. F. (2007). Experimental analysis of neighborhood effects. Econometrica, 75(1), 83-119.

Lusardi, A. (2011). Americans' financial capability, NBER Working Paper No. 17103, National Bureau of Economic Research. http://www.nber.org/papers/w17103.

Ma, J., Gans, J. S., \& Tourky, R. (2018). Market structure in bitcoin mining, NBER Working Paper No. 24242, National Bureau of Economic Research. https://www.nber.org/system/files/working_papers/w24242/w24242.pdf.

Malhotra et al. (2019). Global payments 2019 - Tapping into pockets of growth. Boston Consulting Group. https://www.bcg.com/publications/2019/global-payments-tapping-into-pockets-growth 
Manaa, M., Chimienti, M. T., Adachi, M. M., Athanassiou, P., Balteanu, I., Calza, A., Devaney, C., Diaz Fernandez, E., Eser, F., \& Ganoulis, I. (2019). Crypto-Assets: Implications for financial stability, monetary policy, and payments and market infrastructures, ECB Occasional Paper Series No. 223, European Central Bank (ECB).

https://papers.ssrn.com/sol3/papers.cfm?abstract_id=3391055.

Manski, C. F. (2004). Measuring expectations. Econometrica, 72(5), 1329-1376.

Marian, O. (2013). Are cryptocurrencies super tax havens. Mich. L. Rev. First Impressions, 112, 38. https://papers.ssrn.com/sol3/papers.cfm?abstract_id=2305863\#

Marsh, A. (2020). Responsible investing is a rare field of finance led by women. Now it's hot —and men want in. Fortune Magazine. https://fortune.com/2020/01/24/responsible-esg-investingwomen-finance/

Mechkaroska, D., Dimitrova, V., \& Popovska-Mitrovikj, A. (2018). Analysis of the possibilities for improvement of BlockChain technology. 2018 26th Telecommunications Forum (TELFOR), 1-4.

Miralles-Quirós, M. M., Miralles-Quirós, J. L., \& Redondo Hernández, J. (2019). ESG Performance and shareholder value creation in the banking industry: International differences. Sustainability, 11(5), 1404.

Mora, C., Rollins, R. L., Taladay, K., Kantar, M. B., Chock, M. K., Shimada, M., \& Franklin, E. C. (2018). Bitcoin emissions alone could push global warming above 2 C. Nature Climate Change, 8(11), 931-933.

Nakamoto, S. (2008). Bitcoin: A peer-to-peer electronic cash system. https://bitcoin.org/bitcoin.pdf.

Ostroff, C., \& Elliot, R. (2021). Tesla Buys \$1.5 Billion in Bitcoin. The Wall Street Journal. https://www.wsj.com/articles/tesla-buys-1-5-billion-in-bitcoin-11612791688

Panos, G. A., \& Karkkainen, T. (2020). Financial Literacy and Attitudes to Cryptocurrencies (Working Papers in Responsible Banking \& Finance No. 2020-26). University of Glasgow. https://www.gla.ac.uk/media/Media_766720_smxx.pdf.

Reid, F., \& Harrigan, M. (2013). An analysis of anonymity in the bitcoin system. In Security and privacy in social networks (pp. 197-223). Springer, New York, NY.

Scharfstein, D. S., \& Stein, J. C. (1990). Herd behavior and investment. American Economic Review, $80(3), 465-479$.

Sedgwick, K. (2018). No, Visa Doesn't Handle 24,000 TPS and Neither Does Your Pet Blockchain.Bitcoin. com. https://news.bitcoin.com/no-visa-doesnt-handle-24000-tps-and-neitherdoes-your-pet-blockchain.

Sheth, J. (2020). Impact of Covid-19 on consumer behavior: Will the old habits return or die? Journal of Business Research, 117, 280-283.

Shiller, R. J. (2015). Irrational exuberance: Revised and expanded third edition. Princeton university press.

Statista. (2019). Paid content in Germany 2018. https://de.statista.com/statistik/daten/studie/514832/umfrage/genutzte-zahlungsmethoden-fuerdigitale-inhalte-und-services-in-deutschland/

Su, J. (2019). Hackers Stole Over \$4 Billion From Crypto Crimes In 2019 So Far, Up From \$1.7 Billion In All Of 2018. Forbes Magazine. https://www.forbes.com/sites/jeanbaptiste/2019/08/15/hackers-stole-over-4-billion-from-cryptocrimes-in-2019-so-far-up-from-1-7-billion-in-all-of-2018/

Trabelsi, N. (2018). Are there any volatility spill-over effects among cryptocurrencies and widely 
traded asset classes? Journal of Risk and Financial Management, 11(4), 66.

van Bavel, J. J., Baicker, K., Boggio, P. S., Capraro, V., Cichocka, A., Cikara, M., Crockett, M. J., Crum, A. J., Douglas, K. M., \& Druckman, J. N. (2020). Using social and behavioural science to support COVID-19 pandemic response. Nature human behaviour, 4(5), 460-471.

Yermack, D. (2015). Is Bitcoin a real currency? An economic appraisal. In Handbook of digital currency (pp. 31-43). Academic Press. 


\section{Tables and Figures}

Table 1. Summary Statistics for Pooled Sample and by Country

\begin{tabular}{lccccc}
\hline \hline Variable & $\begin{array}{c}\text { Pooled } \\
\text { sample }\end{array}$ & $\begin{array}{c}\text { German } \\
\text { sample }\end{array}$ & $\begin{array}{c}\text { UK } \\
\text { sample }\end{array}$ & $\begin{array}{c}\text { French } \\
\text { sample }\end{array}$ & $\begin{array}{c}\text { Italian } \\
\text { sample }\end{array}$ \\
\hline Age & 46.57 & 48.21 & 45.00 & 46.52 & 46.87 \\
Female & 0.51 & 0.52 & 0.50 & 0.51 & 0.52 \\
Academic & 0.40 & 0.28 & 0.45 & 0.48 & 0.39 \\
Employed & 0.63 & 0.64 & 0.65 & 0.64 & 0.58 \\
Income & & & & & \\
$\quad$ Below 1,000 & 0.12 & 0.13 & 0.15 & 0.09 & 0.12 \\
$\quad$ 1,001-2,000 & 0.26 & 0.24 & 0.25 & 0.22 & 0.34 \\
$\quad$ 2,001-2,500 & 0.14 & 0.14 & 0.13 & 0.14 & 0.15 \\
$\quad$ 2,501-3,000 & 0.15 & 0.16 & 0.14 & 0.16 & 0.14 \\
$\quad \begin{array}{l}\text { 3,001-4,000 } \\
\text { 4,001-7,000 }\end{array}$ & 0.16 & 0.16 & 0.15 & 0.19 & 0.13 \\
$\quad$ more than 7,000 & 0.14 & 0.15 & 0.13 & 0.17 & 0.10 \\
Real estate owner & 0.03 & 0.02 & 0.05 & 0.03 & 0.01 \\
Bitcoin buyer & 0.60 & 0.36 & 0.62 & 0.61 & 0.80 \\
Financial literacy & 0.11 & 0.12 & 0.11 & 0.09 & 0.12 \\
\hline No. of observations & 1.62 & 1.94 & 1.65 & 1.43 & 1.44 \\
\hline \hline
\end{tabular}

Notes: This table displays the mean values of the covariates. Age is measured in years. Female, academic, employed, real estate owner and Bitcoin buyer are dummy variables. They respectively take on a value of one if the observation is female, has an academic degree, is employed, owns real estate or has bought bitcoins before. Otherwise, they take on a value of zero. Income provides the share of observations in the respective income class. To assess financial literacy, our survey asked respondents to answer the three questions developed by Lusardi (2011). The variable financial literacy provides the mean value of correct answers to these questions. 
Table 2. Balancing Checks

\begin{tabular}{lcccc}
\hline \hline Variable & Central & Privacy & CO2 & Public \\
& $(1)$ & $(2)$ & $(3)$ & $(4)$ \\
\hline No. of insignificant covariates to all covariates & $28 / 28$ & $27 / 28$ & $27 / 28$ & $28 / 28$ \\
$F$-value & 0.95 & 1.14 & 0.75 & 1.08 \\
Prob $>F$ & 0.53 & 0.29 & 0.80 & 0.36 \\
$\mathrm{R}^{2}$ & 0.03 & 0.03 & 0.02 & 0.03 \\
Adjusted $\mathrm{R}^{2}$ & 0.00 & 0.00 & -0.01 & 0.00 \\
\hline No. of observations & 782 & 796 & 776 & 841 \\
\hline \hline
\end{tabular}

Notes: The table shows summary statistics from regressions of treatment assignment (T1 to T4, compared to assignment to the control group) on the covariates including country (3), age, female, academic degree, income (6), financial assets, financial literary and constant. The treatments are: T1 = central bank warning, T2 = lack of privacy, $\mathrm{T} 3=\mathrm{CO}_{2}$-emissions, $\mathrm{T} 4=$ increased public acceptance. The first row shows the number of balanced covariates to all covariates included. The second and third row shows F-value and p-value from an F-test of joint significance. The final two rows show the $\mathrm{R}^{2}$ and adjusted $\mathrm{R}^{2}$. 
Figure 1. The Price Trend of Bitcoin

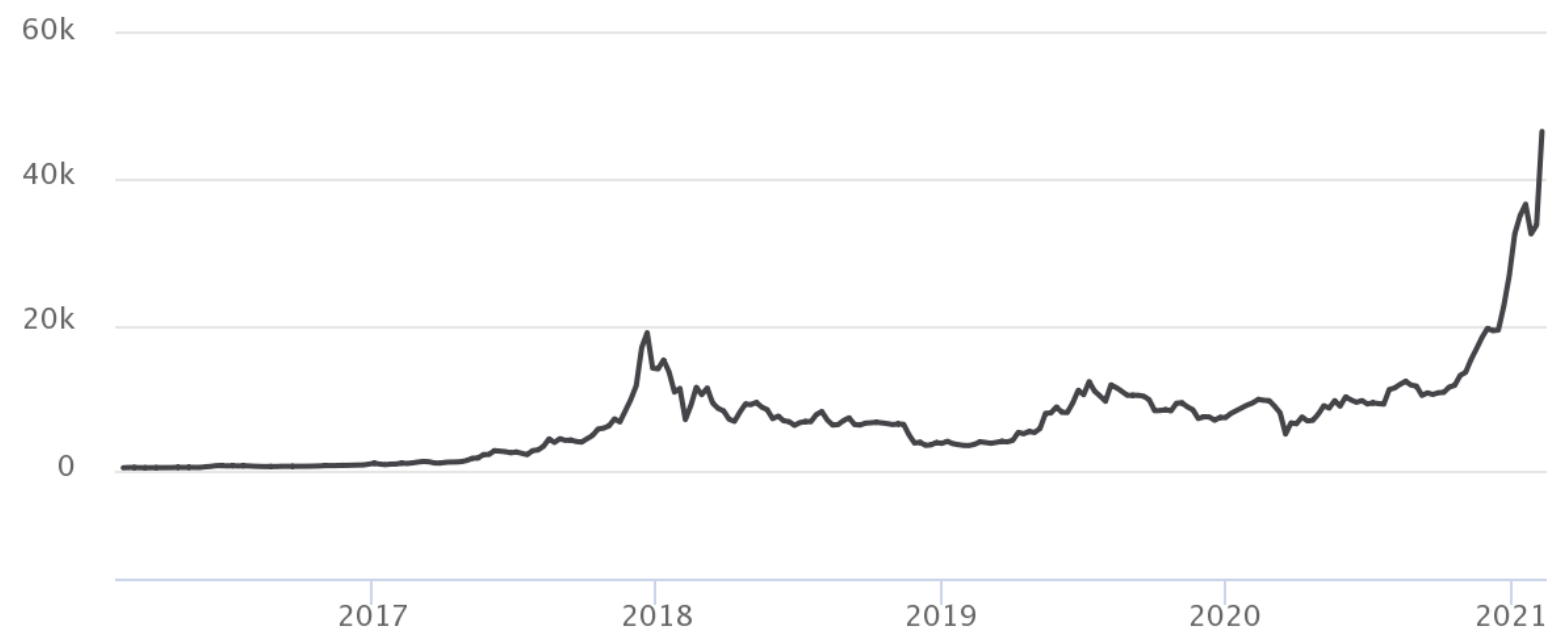

Source: Coinmarketcap (2021). Accessed 2021-02-11. Link: https://coinmarketcap.com/currencies/bitcoin. 
Figure 2. Estimated Regression Coefficients for Pooled Sample and by Country

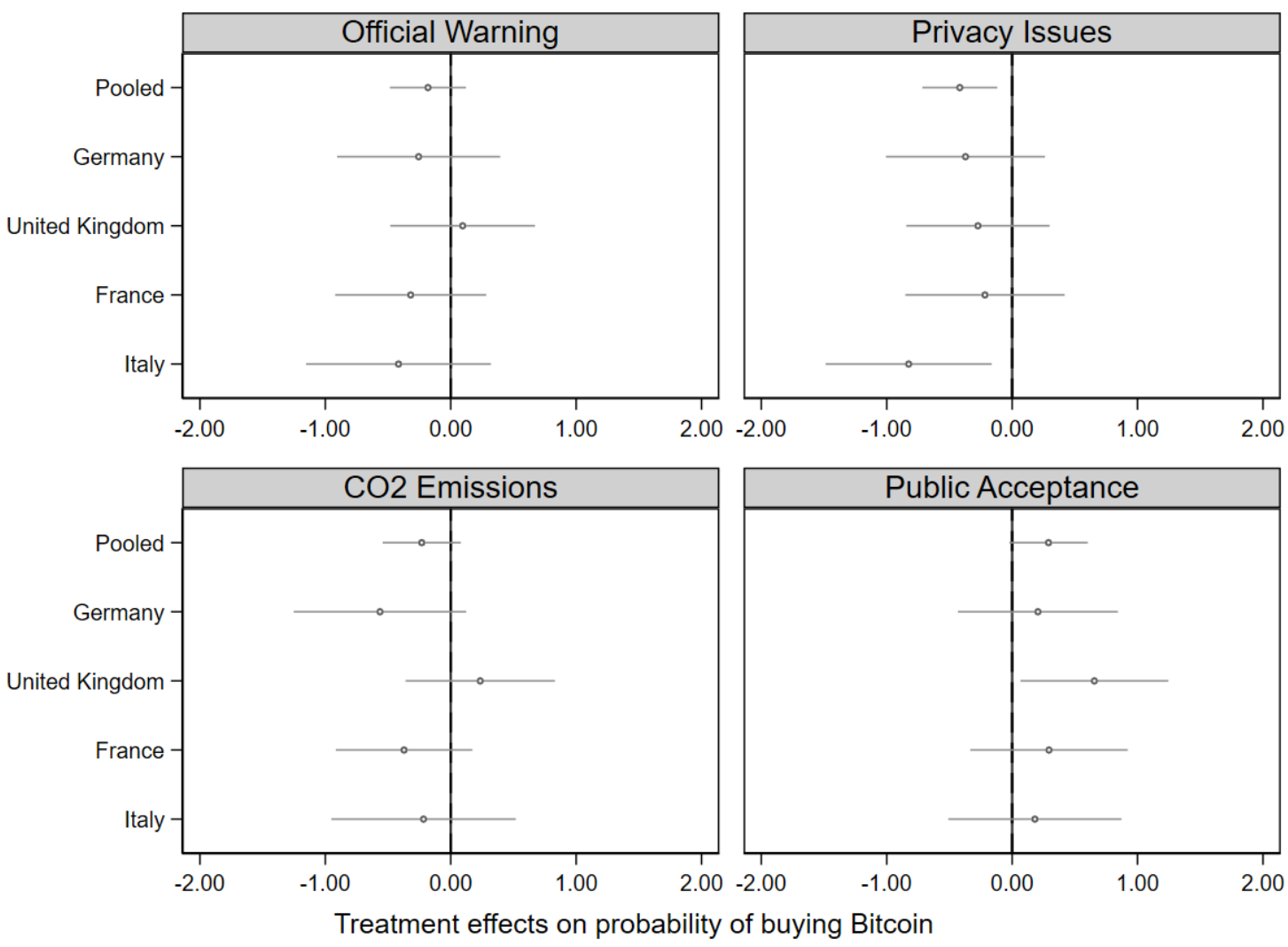

Notes: The four figures show the treatment effects of the four information treatments on Bitcoin demand for the pooled sample and by country. Each figure shows the point estimates and $95 \%$ confidence intervals of the respective treatment indicator $\left(\mathrm{T} 1=\right.$ central bank warning, $\mathrm{T} 2=$ lack of privacy, $\mathrm{T} 3=\mathrm{CO}_{2}$ emissions, and $\mathrm{T} 4=$ public acceptance). The point estimates come from a regression of the probability of buying Bitcoin within the next two weeks on the respective treatment indicator, country-fixed effects, and a set of covariates. The covariates include age, age (squared), female, academic degree, employment, income (6 categories), real estate ownership, financial literacy, Bitcoin experiences, and the answers from the elicitation stage. 


\section{Figure 3. Estimated Regression Coefficients for Pooled Sample and by Demographic Subgroups}
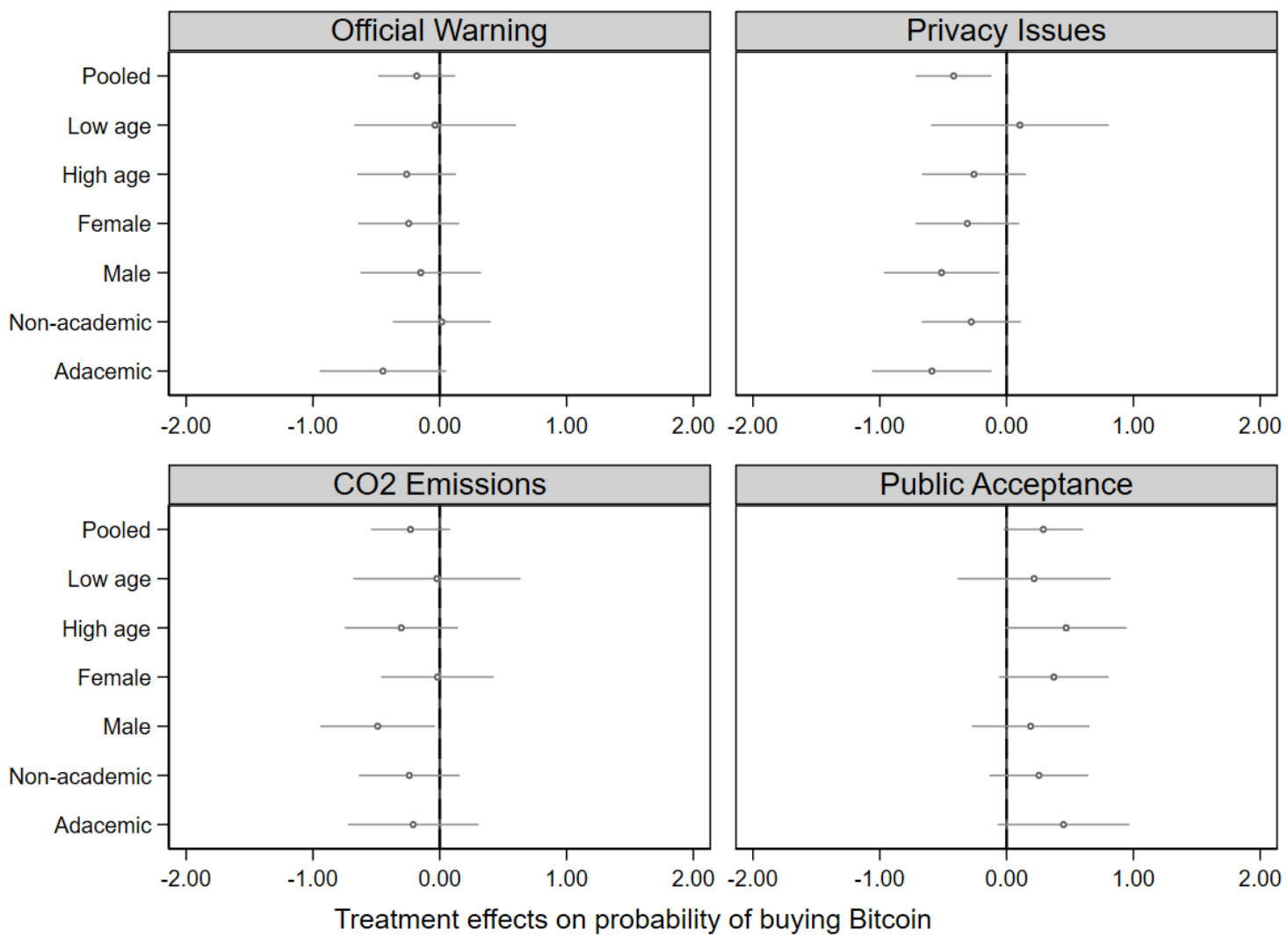

Notes: The four figures show the treatment effects of the four information treatments on Bitcoin demand for the pooled sample and by demographic subgroups. Each figure shows the point estimates and $95 \%$ confidence intervals of the respective treatment indicator $\left(\mathrm{T} 1=\right.$ central bank warning, $\mathrm{T} 2=$ lack of privacy, $\mathrm{T} 3=\mathrm{CO}_{2}$ emissions, and T4=public acceptance). The point estimates come from a regression of the probability of buying Bitcoin within the next two weeks on the respective treatment indicator, country-fixed effects, and a set of covariates except the one indicating the subgroup considered. The covariates include age, age (squared), female, academic degree, employment, income (6 categories), real estate ownership, financial literacy, Bitcoin experiences, and the answers from the elicitation stage. We also checked for differences between employed an unemployed people, but found no significant effects. The low age group comprises the lowest tertile of the age distribution, while the high age group comprises the highest tertile. We built the other subgroups using binary variables indicating gender and educational status. 


\section{Figure 4. Estimated Regression Coefficients for Pooled Sample and by Financial Subgroups}
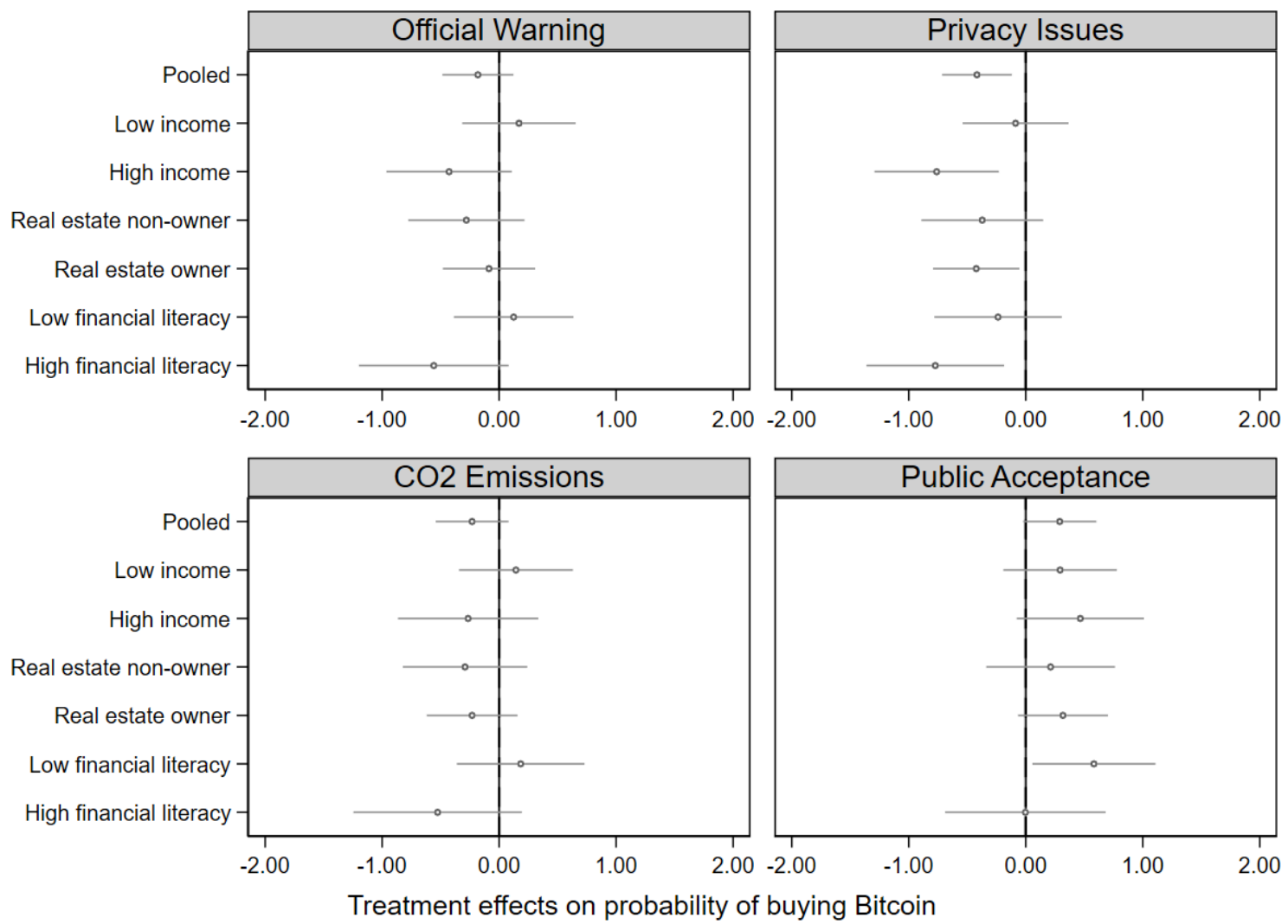

Notes: The four figures show the treatment effects of the four information treatments on Bitcoin demand for the pooled sample and by financial subgroups. Each figure shows the point estimates and $95 \%$ confidence intervals of the respective treatment indicator $\left(\mathrm{T} 1=\right.$ central bank warning, $\mathrm{T} 2=$ lack of privacy, $\mathrm{T} 3=\mathrm{CO}_{2}$ emissions, and T4=public acceptance). The point estimates come from a regression of the probability of buying Bitcoin within the next two weeks on the respective treatment indicator, country-fixed effects, and a set of covariates except the one indicating the subgroup considered. The covariates include age, age (squared), female, academic degree, employment, income (6 categories), real estate ownership, financial literacy, Bitcoin experiences, and the answers from the elicitation stage. We also checked for differences between people who have already bought bitcoins before, and those who did not. We report the corresponding results in Figure A.2 in Appendix A. The low-income group comprises the lowest tertile of the income distribution, while the high-income group comprises the highest tertile. The same is true for the subgroups that base on financial literacy. We build the other two subgroups using a binary variable that indicates real estate ownership. 


\section{Figure 5. Estimated Regression Coefficients for Pooled Sample and by Elicitation Stage Subgroups}
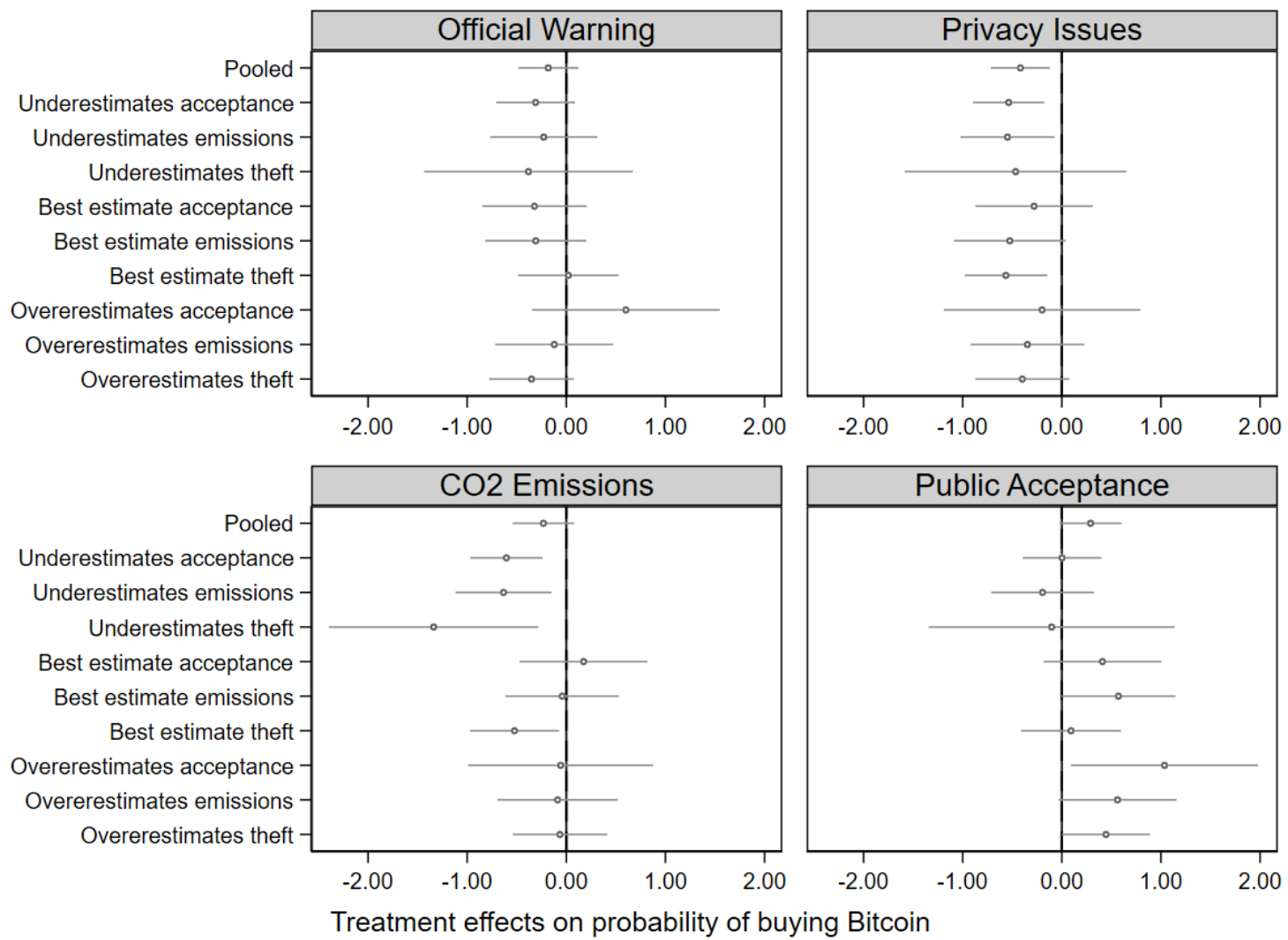

Notes: The four figures show the treatment effects of the four information treatments on Bitcoin demand for the pooled sample and by answers given in the elicitation stage of the questionnaire. Each figure shows the point estimates and $95 \%$ confidence intervals of the respective treatment indicator $(\mathrm{T} 1=$ central bank warning, $\mathrm{T} 2=\mathrm{lack}$ of privacy, $\mathrm{T} 3=\mathrm{CO}_{2}$ emissions, and $\mathrm{T} 4=$ public acceptance). The point estimates come from a regression of the probability of buying Bitcoin within the next two weeks on the respective treatment indicator, country-fixed effects, and a set of covariates except the one indicating the subgroup considered. The covariates include age, age (squared), female, academic degree, employment, income (6 categories), real estate ownership, financial literacy, Bitcoin experiences, and the answers from the elicitation stage. To categorize the answers given in the elicitation stage, we placed a $33.3 \%$ band around each of the true values. Answers that lie within the $33.3 \%$ band belong to the "best estimates" group. Answers above this band belong to the "overestimates" group, and answers below this band belong to the "underestimates" group. We also experimented with a 50\% bandwidth, but the results did not change significantly. 


\section{Appendix A: Tables and Figures}

Table A.1. Ability of Covariates to Predict Treatment Status

\begin{tabular}{|c|c|c|c|c|c|c|c|c|}
\hline Covariate & $\mathrm{T} 1$ & $\mathrm{p}$-value & $\mathrm{T} 2$ & $\mathrm{p}$-value & $\mathrm{T} 3$ & $\mathrm{p}$-value & $\mathrm{T} 4$ & $\mathrm{p}$-value \\
\hline Age & -0.002 & 0.096 & -0.002 & 0.067 & -0.002 & 0.029 & -0.001 & 0.216 \\
\hline Female & -0.034 & 0.300 & -0.058 & 0.095 & -0.003 & 0.924 & -0.021 & 0.548 \\
\hline Academic & -0.012 & 0.717 & 0.033 & 0.358 & 0.019 & 0.600 & 0.061 & 0.079 \\
\hline Employed & -0.001 & 0.968 & -0.006 & 0.877 & -0.011 & 0.764 & -0.047 & 0.177 \\
\hline \multicolumn{9}{|l|}{ Income } \\
\hline Below 1,000 & 0.045 & 0.383 & -0.010 & 0.859 & 0.055 & 0.303 & 0.035 & 0.520 \\
\hline $1,001-2,000$ & -0.041 & 0.302 & 0.001 & 0.986 & -0.008 & 0.850 & 0.008 & 0.831 \\
\hline $2,001-2,500$ & 0.002 & 0.962 & -0.047 & 0.358 & -0.015 & 0.761 & -0.113 & 0.030 \\
\hline $2,501-3,000$ & -0.016 & 0.747 & 0.019 & 0.699 & -0.053 & 0.310 & 0.045 & 0.352 \\
\hline $3,001-4,000$ & 0.049 & 0.283 & -0.021 & 0.681 & -0.010 & 0.839 & -0.011 & 0.831 \\
\hline $4,001-7,000$ & -0.026 & 0.623 & 0.067 & 0.185 & 0.024 & 0.651 & 0.034 & 0.512 \\
\hline Above 7,000 & 0.013 & 0.894 & -0.061 & 0.592 & 0.066 & 0.502 & -0.046 & 0.675 \\
\hline Real estate owner & -0.032 & 0.351 & -0.017 & 0.637 & -0.072 & 0.040 & -0.052 & 0.136 \\
\hline Financial literacy & -0.038 & 0.084 & -0.008 & 0.733 & -0.004 & 0.849 & 0.017 & 0.449 \\
\hline Bitcoin buyer & 0.103 & 0.037 & 0.008 & 0.896 & 0.064 & 0.253 & -0.029 & 0.624 \\
\hline Underestimate public acceptance & -0.033 & 0.334 & -0.038 & 0.290 & -0.057 & 0.120 & -0.007 & 0.834 \\
\hline Best estimate public acceptance & 0.036 & 0.283 & 0.033 & 0.353 & 0.055 & 0.124 & 0.018 & 0.603 \\
\hline Overestimate public acceptance & -0.024 & 0.762 & 0.018 & 0.820 & -0.004 & 0.957 & -0.062 & 0.453 \\
\hline Underestimate $\mathrm{CO}_{2}$ emissions & -0.005 & 0.893 & -0.012 & 0.757 & -0.041 & 0.306 & 0.018 & 0.635 \\
\hline Best estimate $\mathrm{CO}_{2}$ emissions & -0.014 & 0.672 & -0.015 & 0.672 & -0.025 & 0.468 & -0.020 & 0.560 \\
\hline Overestimate $\mathrm{CO}_{2}$ emissions & 0.025 & 0.517 & 0.034 & 0.409 & 0.075 & 0.060 & 0.008 & 0.848 \\
\hline Underestimate value stolen & -0.019 & 0.770 & -0.059 & 0.402 & 0.025 & 0.699 & -0.009 & 0.889 \\
\hline Best estimate value stolen & -0.026 & 0.432 & -0.008 & 0.808 & -0.060 & 0.086 & 0.022 & 0.517 \\
\hline Overestimate value stolen & 0.031 & 0.352 & 0.023 & 0.513 & 0.052 & 0.136 & -0.020 & 0.565 \\
\hline Number of observations & 505 & & 431 & & 428 & & 458 & \\
\hline
\end{tabular}

Notes: Each row displays the coefficients and $p$-value from separate regressions of treatment assignment (T1 to $\mathrm{T} 4$, compared to assignment to the control group) on the covariate. The treatments are: $\mathrm{T} 1=$ central bank warning, $\mathrm{T} 2=$ lack of privacy, $\mathrm{T} 3=\mathrm{CO}_{2}$-emissions, $\mathrm{T} 4=$ increased public acceptance. 
Table A.2. Distribution of Subgroups by Elicitation Questions

\begin{tabular}{|c|c|c|c|}
\hline & Median & Frequency & Percent \\
\hline \multicolumn{4}{|c|}{ Public acceptance (true value: 25 ) } \\
\hline Underestimates & 5 & 1,153 & 51.87 \\
\hline Best estimates & 25 & 702 & 31.58 \\
\hline Overestimates & 70 & 368 & 16.55 \\
\hline \multicolumn{4}{|c|}{$\mathrm{CO}_{2}$ emissions (true value: 22 ) } \\
\hline Underestimates & 1 & 758 & 34.10 \\
\hline Best estimates & 20 & 759 & 34.14 \\
\hline Overestimates & 374.5 & 706 & 31.76 \\
\hline \multicolumn{4}{|c|}{ Value of stolen bitcoins (true value: 4) } \\
\hline Underestimates & 0 & 1,153 & 51.87 \\
\hline Best estimates & 3 & 702 & 31.58 \\
\hline Overestimates & 100 & 368 & 16.55 \\
\hline Observations & & 2,223 & 100.00 \\
\hline
\end{tabular}

Notes: To form the subgroups, we put a $33.3 \%$ band around each of the true values. Answers that lie within the $33.3 \%$ band belong to the "best estimates" group. Answers above this band belong to the "overestimates" group, and answers below this band belong to the "underestimates" group. 
Figure A.1. Estimated Regression Coefficients (Pooled Model): Choice of Specification
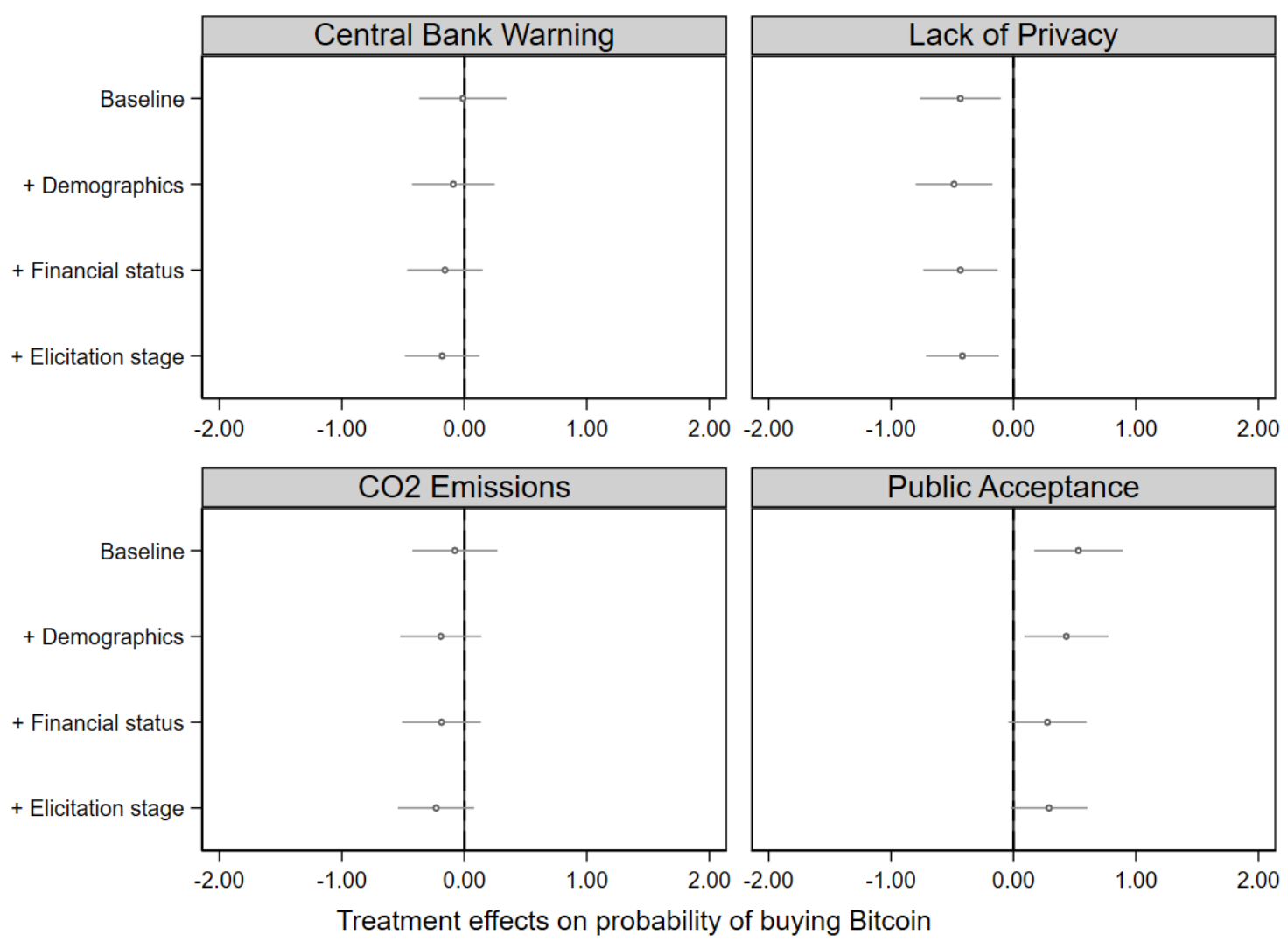

Notes: The four figures show the treatment effects of the four information treatments on Bitcoin demand by model specification. Each figure shows the point estimates and $95 \%$ confidence intervals of the respective treatment indicator $\left(\mathrm{T} 1=\right.$ central bank warning, $\mathrm{T} 2=$ lack of privacy, $\mathrm{T} 3=\mathrm{CO}_{2}$ emissions, and $\mathrm{T} 4=$ public acceptance). The point estimates come from different specifications of the regression model. The baseline model is a regression of the outcome (probability of buying Bitcoin) on the respective treatment indicator and country fixed effects only. For the second specification, we added demographic variables including age, age (squared), female, academic degree, employment status, income (6 categories), and real estate ownership. For the third specification, we added financial literacy and a binary variable indicating whether the person has bought bitcoins before or not. For the fourth specification, we added three variables indicating whether the person has underestimated, overestimated, or correctly estimated (1) the public acceptance of Bitcoin, (2) the $\mathrm{CO}_{2}$ emissions from Bitcoin mining, and (3) the value of bitcoins stolen in the first half of 2019. We also experimented with different specifications, for example, by defining the control variables differently. However, the fourth specification presented above provided the most significant and robust results. 
Figure A.2. Estimated Regression Coefficients for Pooled Sample and by Bitcoin Experiences Subgroups

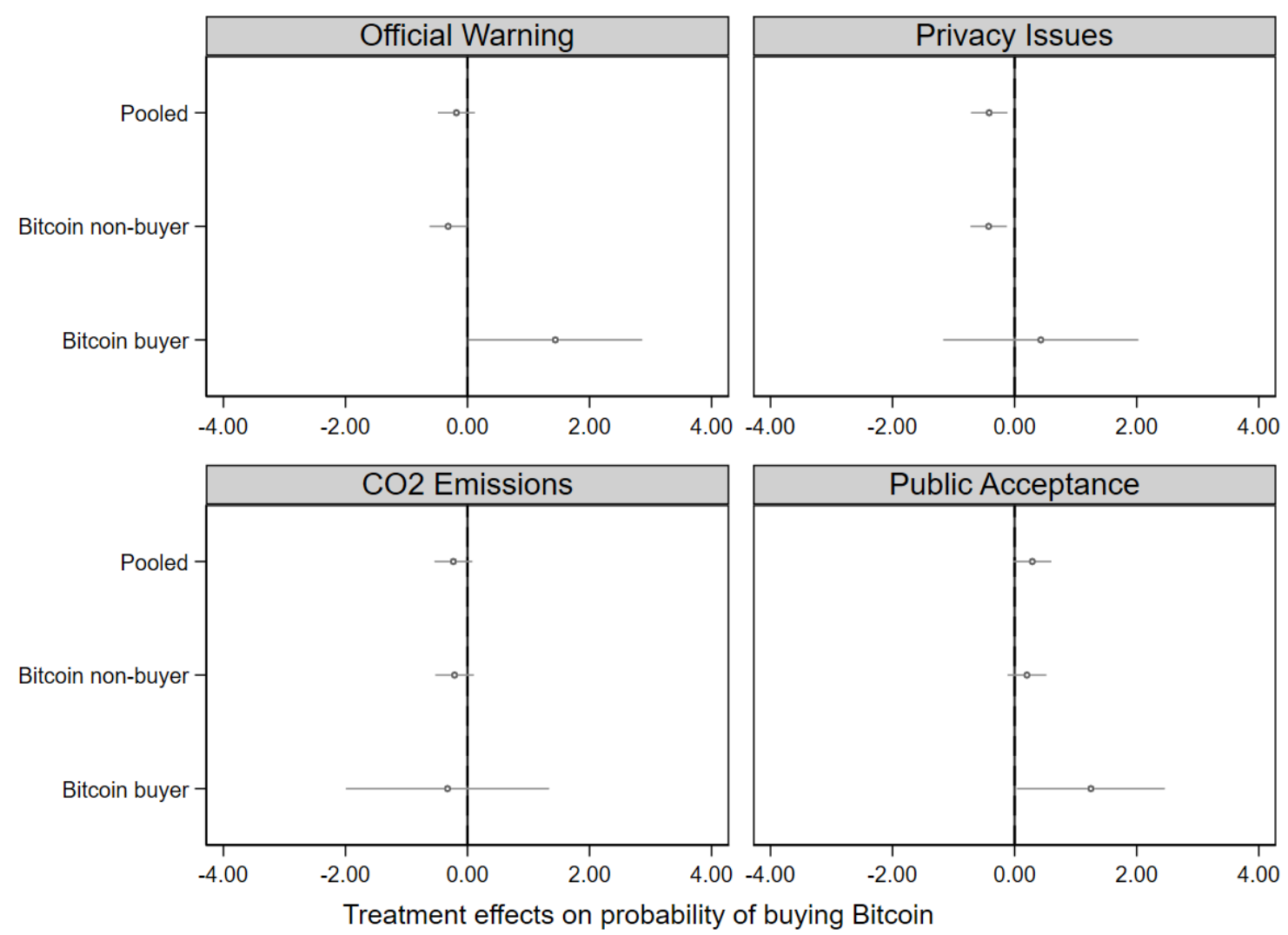

Notes: The four figures show the treatment effects of the four information treatments on Bitcoin demand for the pooled sample and the subgroups of Bitcoin buyers versus non-buyers. Each figure shows the point estimates and $95 \%$ confidence intervals of the respective treatment indicator $(\mathrm{T} 1=$ central bank warning, $\mathrm{T} 2=$ lack of privacy, $\mathrm{T} 3=\mathrm{CO}_{2}$ emissions, and $\mathrm{T} 4=$ public acceptance). The point estimates come from a regression of the probability of buying Bitcoin within the next two weeks on the respective treatment indicator, country-fixed effects, and a set of covariates except the one indicating the subgroup considered. The covariates include age, age (squared), female, academic degree, employment, income (6 categories), real estate ownership, financial literacy, and the answers from the elicitation stage. To categorize the answers given in the elicitation stage, we placed a 33.3\% band around each of the true values. Answers that lie within the $33.3 \%$ band belong to the "best estimates" group. Answers above this band belong to the "overestimates" group, and answers below this band belong to the "underestimates" group. We also experimented with a $50 \%$ bandwidth, but the results did not change significantly. 
Table A.3. Regression Table for Pooled Sample

\begin{tabular}{|c|c|c|c|c|}
\hline & $\begin{array}{c}(1) \\
\text { Official Warning }\end{array}$ & $\begin{array}{c}(2) \\
\text { Privacy Issues }\end{array}$ & $\begin{array}{c}(3) \\
\mathrm{CO} 2 \text { Emissions }\end{array}$ & $\begin{array}{c}\text { (4) } \\
\text { Public Acceptance }\end{array}$ \\
\hline \multirow[t]{2}{*}{ Treatment indicator } & -0.182 & $-0.417 * * *$ & -0.231 & $0.291^{*}$ \\
\hline & $(0.155)$ & $(0.152)$ & $(0.159)$ & $(0.159)$ \\
\hline \multirow[t]{2}{*}{ United Kingdom } & $-0.495 * *$ & $-0.607 * * *$ & -0.347 & $-0.434 *$ \\
\hline & $(0.228)$ & $(0.225)$ & $(0.248)$ & $(0.235)$ \\
\hline \multirow[t]{2}{*}{ France } & -0.278 & -0.287 & -0.287 & -0.274 \\
\hline & $(0.240)$ & $(0.235)$ & $(0.256)$ & $(0.244)$ \\
\hline \multirow[t]{2}{*}{ Italy } & 0.128 & -0.080 & 0.173 & 0.232 \\
\hline & $(0.251)$ & $(0.248)$ & $(0.272)$ & $(0.262)$ \\
\hline \multirow[t]{2}{*}{ Age } & 0.014 & 0.009 & 0.007 & 0.016 \\
\hline & $(0.037)$ & $(0.037)$ & $(0.039)$ & $(0.037)$ \\
\hline \multirow[t]{2}{*}{ Age squared } & -0.000 & -0.000 & -0.000 & -0.000 \\
\hline & $(0.000)$ & $(0.000)$ & $(0.000)$ & $(0.000)$ \\
\hline \multirow[t]{2}{*}{ Female } & $-0.646 * * *$ & $-0.572 * * *$ & $-0.590 * * *$ & $-0.593 * * *$ \\
\hline & $(0.165)$ & $(0.159)$ & $(0.170)$ & $(0.173)$ \\
\hline \multirow[t]{2}{*}{ Academic } & -0.046 & 0.094 & $0.302 *$ & $0.300 *$ \\
\hline & $(0.170)$ & $(0.165)$ & $(0.174)$ & $(0.174)$ \\
\hline \multirow[t]{2}{*}{ Employed } & 0.131 & 0.275 & 0.246 & 0.194 \\
\hline & $(0.196)$ & $(0.191)$ & $(0.209)$ & $(0.204)$ \\
\hline \multicolumn{5}{|l|}{ Income } \\
\hline \multirow[t]{2}{*}{$1,001-2,000$} & 0.273 & 0.089 & 0.302 & 0.274 \\
\hline & $(0.271)$ & $(0.265)$ & $(0.291)$ & $(0.279)$ \\
\hline \multirow[t]{2}{*}{$2,001-2,500$} & 0.368 & 0.513 & 0.517 & $0.830 * * *$ \\
\hline & $(0.303)$ & $(0.316)$ & $(0.331)$ & $(0.312)$ \\
\hline \multirow[t]{2}{*}{$2,501-3,000$} & $0.822 * * *$ & $0.590 *$ & $0.874 * * *$ & $1.017 * * *$ \\
\hline & $(0.318)$ & $(0.304)$ & $(0.331)$ & $(0.324)$ \\
\hline \multirow[t]{2}{*}{$3,001-4,000$} & 0.465 & 0.402 & $0.825^{* *}$ & $0.919 * * *$ \\
\hline & $(0.314)$ & $(0.312)$ & $(0.339)$ & $(0.318)$ \\
\hline \multirow[t]{2}{*}{$4,001-7,000$} & $0.728 * *$ & 0.323 & $0.833 * *$ & $1.152 * * *$ \\
\hline & $(0.341)$ & $(0.338)$ & $(0.362)$ & $(0.356)$ \\
\hline \multirow[t]{2}{*}{ Above 7,000} & 0.044 & 0.485 & 0.199 & 0.550 \\
\hline & $(0.492)$ & $(0.535)$ & $(0.575)$ & $(0.530)$ \\
\hline \multirow[t]{2}{*}{ Real estate owner } & -0.024 & -0.083 & -0.231 & -0.304 \\
\hline & $(0.178)$ & $(0.180)$ & $(0.195)$ & $(0.187)$ \\
\hline \multirow[t]{2}{*}{ Financial literacy } & $-0.205^{*}$ & -0.136 & $-0.244 * *$ & $-0.198 *$ \\
\hline & $(0.115)$ & $(0.115)$ & $(0.124)$ & $(0.119)$ \\
\hline \multirow[t]{2}{*}{ Bitcoin buyer } & $3.518 * * *$ & $3.017 * * *$ & $2.630 * * *$ & $3.259 * * *$ \\
\hline & $(0.264)$ & $(0.275)$ & $(0.286)$ & $(0.257)$ \\
\hline Best estimate public acceptance & $0.524 * * *$ & $0.657 * * *$ & $0.965 * * *$ & $0.735 * * *$ \\
\hline & $(0.186)$ & $(0.181)$ & $(0.195)$ & $(0.188)$ \\
\hline Overestimate public acceptance & $1.377 * * *$ & $1.084 * * *$ & $1.359 * * *$ & $1.325 * * *$ \\
\hline & $(0.233)$ & $(0.237)$ & $(0.239)$ & $(0.247)$ \\
\hline Best estimate $\mathrm{CO}_{2}$ emissions & -0.080 & -0.029 & 0.129 & 0.283 \\
\hline & $(0.200)$ & $(0.196)$ & $(0.206)$ & $(0.202)$ \\
\hline Overestimate $\mathrm{CO}_{2}$ emissions & -0.312 & -0.322 & -0.267 & -0.156 \\
\hline & $(0.208)$ & $(0.205)$ & $(0.218)$ & $(0.209)$ \\
\hline Best estimate value stolen & 0.208 & -0.016 & 0.108 & 0.059 \\
\hline & $(0.295)$ & $(0.288)$ & $(0.315)$ & $(0.310)$ \\
\hline Overestimate value stolen & 0.195 & 0.350 & $0.580^{*}$ & 0.345 \\
\hline & $(0.298)$ & $(0.297)$ & $(0.319)$ & $(0.308)$ \\
\hline Constant & $1.881 * *$ & $1.942 * *$ & 1.412 & 1.076 \\
\hline & $(0.876)$ & $(0.870)$ & $(0.926)$ & $(0.929)$ \\
\hline Observations & 782 & 796 & 776 & 841 \\
\hline R squared & 0.374 & 0.306 & 0.306 & 0.357 \\
\hline Adjusted R squared & 0.354 & 0.285 & 0.284 & 0.338 \\
\hline
\end{tabular}


Table A.4. Regression Table for Female Sample

\begin{tabular}{|c|c|c|c|c|}
\hline & $\begin{array}{c}(1) \\
\text { Official Warning }\end{array}$ & $\begin{array}{c}\text { (2) } \\
\text { Privacy Issues }\end{array}$ & $\begin{array}{c}\text { (3) } \\
\mathrm{CO} 2 \text { Emissions }\end{array}$ & $\begin{array}{c}\text { (4) } \\
\text { Public Acceptance }\end{array}$ \\
\hline Treatment indicator & $\begin{array}{l}-0.245 \\
(0.203)\end{array}$ & $\begin{array}{l}-0.310 \\
(0.208)\end{array}$ & $\begin{array}{l}-0.018 \\
(0.226)\end{array}$ & $\begin{array}{l}0.373^{*} \\
(0.220)\end{array}$ \\
\hline United Kingdom & $\begin{array}{l}-0.124 \\
(0.293)\end{array}$ & $\begin{array}{l}-0.489 \\
(0.312)\end{array}$ & $\begin{array}{l}-0.321 \\
(0.356)\end{array}$ & $\begin{array}{l}-0.385 \\
(0.320)\end{array}$ \\
\hline France & $\begin{array}{l}-0.366 \\
(0.308)\end{array}$ & $\begin{array}{l}-0.354 \\
(0.323)\end{array}$ & $\begin{array}{l}-0.459 \\
(0.376)\end{array}$ & $\begin{array}{l}-0.334 \\
(0.343)\end{array}$ \\
\hline Italy & $\begin{array}{l}-0.124 \\
(0.325)\end{array}$ & $\begin{array}{c}0.017 \\
(0.350)\end{array}$ & $\begin{array}{c}0.227 \\
(0.390)\end{array}$ & $\begin{array}{c}0.304 \\
(0.352)\end{array}$ \\
\hline Age & $\begin{array}{c}0.003 \\
(0.048)\end{array}$ & $\begin{array}{l}-0.012 \\
(0.050)\end{array}$ & $\begin{array}{l}-0.034 \\
(0.054)\end{array}$ & $\begin{array}{l}-0.021 \\
(0.050)\end{array}$ \\
\hline Age squared & $\begin{array}{l}-0.000 \\
(0.001)\end{array}$ & $\begin{array}{l}-0.000 \\
(0.001)\end{array}$ & $\begin{array}{c}0.000 \\
(0.001)\end{array}$ & $\begin{array}{c}0.000 \\
(0.001)\end{array}$ \\
\hline Academic & $\begin{array}{l}-0.019 \\
(0.216)\end{array}$ & $\begin{array}{c}0.251 \\
(0.230)\end{array}$ & $\begin{array}{c}0.396 \\
(0.253)\end{array}$ & $\begin{array}{l}0.419^{*} \\
(0.244)\end{array}$ \\
\hline Employed & $\begin{array}{l}-0.172 \\
(0.233)\end{array}$ & $\begin{array}{c}0.109 \\
(0.247)\end{array}$ & $\begin{array}{c}0.030 \\
(0.277)\end{array}$ & $\begin{array}{c}0.105 \\
(0.262)\end{array}$ \\
\hline Income & & & & \\
\hline $1,001-2,000$ & $\begin{array}{c}0.444 \\
(0.327)\end{array}$ & $\begin{array}{l}-0.051 \\
(0.336)\end{array}$ & $\begin{array}{c}0.182 \\
(0.372)\end{array}$ & $\begin{array}{l}-0.020 \\
(0.350)\end{array}$ \\
\hline $2,001-2,500$ & $\begin{array}{c}0.356 \\
(0.376)\end{array}$ & $\begin{array}{c}0.619 \\
(0.421)\end{array}$ & $\begin{array}{l}0.798^{*} \\
(0.449)\end{array}$ & $\begin{array}{c}0.508 \\
(0.409)\end{array}$ \\
\hline $2,501-3,000$ & $\begin{array}{c}0.441 \\
(0.396)\end{array}$ & $\begin{array}{c}0.618 \\
(0.397)\end{array}$ & $\begin{array}{l}0.773 * \\
(0.435)\end{array}$ & $\begin{array}{c}0.679 \\
(0.431)\end{array}$ \\
\hline $3,001-4,000$ & $\begin{array}{c}0.247 \\
(0.389)\end{array}$ & $\begin{array}{c}0.275 \\
(0.426)\end{array}$ & $\begin{array}{c}0.411 \\
(0.453)\end{array}$ & $\begin{array}{l}0.919 * * \\
(0.421)\end{array}$ \\
\hline $4,001-7,000$ & $\begin{array}{l}1.149 * * \\
(0.470)\end{array}$ & $\begin{array}{c}0.689 \\
(0.489)\end{array}$ & $\begin{array}{l}1.107 * * \\
(0.520)\end{array}$ & $\begin{array}{l}1.148 * * \\
(0.524)\end{array}$ \\
\hline Above 7,000 & $\begin{array}{c}0.115 \\
(0.611)\end{array}$ & $\begin{array}{l}-0.078 \\
(0.713)\end{array}$ & $\begin{array}{l}-0.239 \\
(0.863)\end{array}$ & $\begin{array}{c}0.792 \\
(0.720)\end{array}$ \\
\hline Real estate owner & $\begin{array}{c}0.178 \\
(0.235)\end{array}$ & $\begin{array}{l}-0.133 \\
(0.253)\end{array}$ & $\begin{array}{l}-0.177 \\
(0.279)\end{array}$ & $\begin{array}{l}-0.322 \\
(0.264)\end{array}$ \\
\hline Financial literacy & $\begin{array}{c}-0.438 * * * \\
(0.150)\end{array}$ & $\begin{array}{c}-0.292 * \\
(0.158)\end{array}$ & $\begin{array}{c}-0.216 \\
(0.180)\end{array}$ & $\begin{array}{c}-0.476^{* * *} \\
(0.168)\end{array}$ \\
\hline Bitcoin buyer & $\begin{array}{c}4.158^{* * * *} \\
(0.403)\end{array}$ & $\begin{array}{c}2.139 * * * \\
(0.454)\end{array}$ & $\begin{array}{c}2.681 * * * \\
(0.494)\end{array}$ & $\begin{array}{c}2.554 * * * \\
(0.428)\end{array}$ \\
\hline Best estimate public acceptance & $\begin{array}{c}0.851^{* * *} \\
(0.243)\end{array}$ & $\begin{array}{c}1.019 * * * \\
(0.247)\end{array}$ & $\begin{array}{c}0.718 * * * \\
(0.272)\end{array}$ & $\begin{array}{c}0.949 * * * \\
(0.252)\end{array}$ \\
\hline Overestimate public acceptance & $\begin{array}{c}1.393 * * * \\
(0.298)\end{array}$ & $\begin{array}{c}1.334 * * * \\
(0.320)\end{array}$ & $\begin{array}{c}1.399 * * * \\
(0.332)\end{array}$ & $\begin{array}{c}1.396 * * * \\
(0.337)\end{array}$ \\
\hline Best estimate $\mathrm{CO}_{2}$ emissions & $\begin{array}{c}-0.151 \\
(0.266)\end{array}$ & $\begin{array}{c}0.067 \\
(0.278)\end{array}$ & $\begin{array}{c}-0.128 \\
(0.300)\end{array}$ & $\begin{array}{c}0.013 \\
(0.286)\end{array}$ \\
\hline Overestimate $\mathrm{CO}_{2}$ emissions & $\begin{array}{c}-0.548^{*} \\
(0.280)\end{array}$ & $\begin{array}{c}-0.585^{* *} \\
(0.288)\end{array}$ & $\begin{array}{c}-0.724 * * \\
(0.313)\end{array}$ & $\begin{array}{l}-0.410 \\
(0.304)\end{array}$ \\
\hline Best estimate value stolen & $\begin{array}{c}0.334 \\
(0.438)\end{array}$ & $\begin{array}{l}-0.169 \\
(0.436)\end{array}$ & $\begin{array}{c}0.209 \\
(0.514)\end{array}$ & $\begin{array}{c}0.392 \\
(0.482)\end{array}$ \\
\hline Overestimate value stolen & $\begin{array}{l}-0.149 \\
(0.445)\end{array}$ & $\begin{array}{c}0.092 \\
(0.451)\end{array}$ & $\begin{array}{c}0.552 \\
(0.515)\end{array}$ & $\begin{array}{c}0.425 \\
(0.479)\end{array}$ \\
\hline Constant & $\begin{array}{l}1.971^{*} \\
(1.122)\end{array}$ & $\begin{array}{l}2.098^{*} \\
(1.157)\end{array}$ & $\begin{array}{c}1.918 \\
(1.287)\end{array}$ & $\begin{array}{c}1.643 \\
(1.213)\end{array}$ \\
\hline Observations & 406 & 405 & 379 & 424 \\
\hline R squared & 0.371 & 0.251 & 0.254 & 0.274 \\
\hline Adjusted R squared & 0.333 & 0.205 & 0.206 & 0.232 \\
\hline
\end{tabular}


Table A.5. Regression Table for Male Sample

\begin{tabular}{|c|c|c|c|c|}
\hline & $\begin{array}{c}\text { (1) } \\
\text { Official Warning }\end{array}$ & $\begin{array}{c}\text { (2) } \\
\text { Privacy Issues }\end{array}$ & $\begin{array}{c}(3) \\
\mathrm{CO} 2 \text { Emissions } \\
\end{array}$ & $\begin{array}{c}\text { (4) } \\
\text { Public Acceptance }\end{array}$ \\
\hline \multirow[t]{2}{*}{ Treatment indicator } & -0.150 & $-0.513 * *$ & $-0.490 * *$ & 0.190 \\
\hline & $(0.241)$ & $(0.232)$ & $(0.230)$ & $(0.236)$ \\
\hline \multirow[t]{2}{*}{ United Kingdom } & $-0.946^{* * *}$ & $-0.755 * *$ & -0.254 & -0.423 \\
\hline & $(0.360)$ & $(0.330)$ & $(0.357)$ & $(0.352)$ \\
\hline \multirow[t]{2}{*}{ France } & -0.246 & -0.116 & -0.052 & -0.063 \\
\hline & $(0.379)$ & $(0.351)$ & $(0.363)$ & $(0.359)$ \\
\hline \multirow[t]{2}{*}{ Italy } & 0.374 & -0.061 & 0.210 & 0.266 \\
\hline & $(0.392)$ & $(0.358)$ & $(0.396)$ & $(0.400)$ \\
\hline \multirow[t]{2}{*}{ Age } & -0.017 & 0.006 & 0.004 & 0.036 \\
\hline & $(0.059)$ & $(0.057)$ & $(0.059)$ & $(0.059)$ \\
\hline \multirow[t]{2}{*}{ Age squared } & -0.000 & -0.000 & -0.000 & -0.001 \\
\hline & $(0.001)$ & $(0.001)$ & $(0.001)$ & $(0.001)$ \\
\hline \multirow[t]{2}{*}{ Academic } & -0.081 & -0.088 & 0.191 & 0.145 \\
\hline & $(0.271)$ & $(0.244)$ & $(0.248)$ & $(0.257)$ \\
\hline \multirow[t]{2}{*}{ Employed } & 0.528 & 0.460 & 0.454 & 0.273 \\
\hline & $(0.342)$ & $(0.307)$ & $(0.327)$ & $(0.332)$ \\
\hline \multicolumn{5}{|l|}{ Income } \\
\hline \multirow[t]{2}{*}{$1,001-2,000$} & -0.063 & 0.173 & 0.326 & 0.766 \\
\hline & $(0.474)$ & $(0.435)$ & $(0.484)$ & $(0.468)$ \\
\hline \multirow[t]{2}{*}{$2,001-2,500$} & 0.249 & 0.405 & 0.349 & $1.396^{* * *}$ \\
\hline & $(0.513)$ & $(0.496)$ & $(0.525)$ & $(0.505)$ \\
\hline \multirow[t]{2}{*}{$2,501-3,000$} & $1.081 * *$ & 0.585 & $0.974^{*}$ & $1.530 * * *$ \\
\hline & $(0.529)$ & $(0.483)$ & $(0.532)$ & $(0.512)$ \\
\hline \multirow[t]{2}{*}{$3,001-4,000$} & 0.542 & 0.543 & $1.035^{*}$ & $1.229 * *$ \\
\hline & $(0.531)$ & $(0.477)$ & $(0.542)$ & $(0.514)$ \\
\hline \multirow[t]{2}{*}{$4,001-7,000$} & 0.462 & 0.168 & 0.654 & $1.523 * * *$ \\
\hline & $(0.530)$ & $(0.502)$ & $(0.552)$ & $(0.535)$ \\
\hline \multirow[t]{2}{*}{ Above 7,000} & -0.192 & 0.998 & 0.499 & 0.625 \\
\hline & $(0.805)$ & $(0.835)$ & $(0.818)$ & $(0.810)$ \\
\hline \multirow[t]{2}{*}{ Real estate owner } & -0.157 & -0.058 & -0.219 & -0.355 \\
\hline & $(0.274)$ & $(0.265)$ & $(0.283)$ & $(0.273)$ \\
\hline \multirow[t]{2}{*}{ Financial literacy } & 0.070 & 0.057 & -0.220 & 0.099 \\
\hline & $(0.181)$ & $(0.173)$ & $(0.175)$ & $(0.175)$ \\
\hline \multirow[t]{2}{*}{ Bitcoin buyer } & $3.155^{* * *}$ & $3.467 * * *$ & $2.606^{* * *}$ & $3.674 * * *$ \\
\hline & $(0.361)$ & $(0.361)$ & $(0.366)$ & $(0.337)$ \\
\hline \multirow[t]{2}{*}{ Best estimate public acceptance } & 0.317 & 0.304 & $1.257 * * *$ & $0.495^{*}$ \\
\hline & $(0.290)$ & $(0.269)$ & $(0.286)$ & $(0.288)$ \\
\hline \multirow[t]{2}{*}{ Overestimate public acceptance } & $1.515^{* * *}$ & $0.969 * * *$ & $1.285^{* * *}$ & $1.265 * * *$ \\
\hline & $(0.373)$ & $(0.363)$ & $(0.355)$ & $(0.377)$ \\
\hline Best estimate $\mathrm{CO}_{2}$ emissions & -0.133 & -0.166 & 0.355 & $0.605^{* *}$ \\
\hline & $(0.306)$ & $(0.285)$ & $(0.294)$ & $(0.295)$ \\
\hline Overestimate $\mathrm{CO}_{2}$ emissions & -0.207 & -0.105 & 0.157 & 0.023 \\
\hline & $(0.317)$ & $(0.299)$ & $(0.312)$ & $(0.300)$ \\
\hline Best estimate value stolen & 0.193 & 0.065 & 0.000 & -0.243 \\
\hline & $(0.412)$ & $(0.395)$ & $(0.415)$ & $(0.417)$ \\
\hline Overestimate value stolen & 0.596 & 0.490 & 0.536 & 0.284 \\
\hline & $(0.414)$ & $(0.402)$ & $(0.424)$ & $(0.414)$ \\
\hline Constant & 1.968 & 1.584 & 1.240 & -0.102 \\
\hline & $(1.417)$ & $(1.358)$ & $(1.411)$ & $(1.469)$ \\
\hline Observations & 376 & 391 & 397 & 417 \\
\hline R squared & 0.413 & 0.374 & 0.370 & 0.433 \\
\hline Adjusted R squared & 0.375 & 0.335 & 0.331 & 0.400 \\
\hline $\begin{array}{l}\text { Notes: The table shows the estimated regres } \\
\text { information treatment: (1) official warning, } \\
\text { probability of buying Bitcoin within the next } \\
\text { the subgroup considered. The reference valu } \\
\text { income ( } 6 \text { categories), real estate ownership, } \\
\text { groups is the group with an income below } € \\
\text { Answers that lie within the } 33.3 \% \text { band bel } \\
\text { this band belong to the "underestimates" gr } \\
\text { results did not change significantly. Robust }\end{array}$ & $\begin{array}{l}\text { cients and robust stand } \\
\text { issues, (3) } \mathrm{CO}_{2} \text { emissi } \\
\text { on the respective treatm } \\
\text { ontry-fixed effects is } \mathrm{G} \\
\text { iteracy, Bitcoin experie }\end{array}$ & $\begin{array}{l}\text { errors for the male s. } \\
\text { and (4) public accep } \\
\text { indicator, country-fi } \\
\text { any. The covariates } \\
\text { and the answers fro }\end{array}$ & $\begin{array}{l}\text { le. Each column show } \\
\text { ce. The estimates com } \\
\text { effects, and a set of co } \\
\text { ude age, age (squared) } \\
\text { he elicitation stage. Th } \\
\text { we placed a } 33.3 \% \text { ban } \\
\text { long to the "overestim } \\
\text { We also experimented }\end{array}$ & $\begin{array}{l}\text { estimates of the respecti } \\
\text { om a linear regression of } t \\
\text { tes except the one indicati } \\
\text { demic degree, employme } \\
\text { ference value for the incor } \\
\text { ound each of the true valu } \\
\text { " group, and answers belc } \\
\text { h a } 50 \% \text { bandwidth, but } t\end{array}$ \\
\hline
\end{tabular}


Table A.6. Regression Table for Low-Age Sample

\begin{tabular}{|c|c|c|c|c|}
\hline & $\begin{array}{c}\text { (1) } \\
\text { Official Warning }\end{array}$ & $\begin{array}{c}(2) \\
\text { Privacy Issues }\end{array}$ & $\begin{array}{c}\text { (3) } \\
\text { CO2 Emissions }\end{array}$ & $\begin{array}{c}\text { Public Acceptance } \\
\text { Pac }\end{array}$ \\
\hline \multirow[t]{2}{*}{ Treatment indicator } & -0.037 & 0.106 & -0.023 & 0.217 \\
\hline & $(0.324)$ & $(0.355)$ & $(0.335)$ & $(0.306)$ \\
\hline \multirow[t]{2}{*}{ United Kingdom } & -0.305 & -0.749 & -0.177 & -0.165 \\
\hline & $(0.436)$ & $(0.510)$ & $(0.542)$ & $(0.451)$ \\
\hline \multirow[t]{2}{*}{ France } & 0.082 & -0.125 & -0.083 & -0.153 \\
\hline & $(0.477)$ & $(0.526)$ & $(0.533)$ & $(0.465)$ \\
\hline \multirow[t]{2}{*}{ Italy } & 0.230 & 0.065 & 0.234 & 0.096 \\
\hline & $(0.496)$ & $(0.586)$ & $(0.582)$ & $(0.517)$ \\
\hline \multirow[t]{2}{*}{ Age } & 0.366 & 0.384 & 0.230 & 0.137 \\
\hline & $(0.298)$ & $(0.338)$ & $(0.340)$ & $(0.304)$ \\
\hline \multirow[t]{2}{*}{ Age squared } & -0.007 & -0.006 & -0.004 & -0.003 \\
\hline & $(0.005)$ & $(0.006)$ & $(0.006)$ & $(0.005)$ \\
\hline \multirow[t]{2}{*}{ Female } & -0.385 & -0.464 & $-0.809 * *$ & -0.402 \\
\hline & $(0.357)$ & $(0.373)$ & $(0.364)$ & $(0.336)$ \\
\hline \multirow[t]{2}{*}{ Academic } & -0.506 & -0.230 & 0.328 & -0.116 \\
\hline & $(0.341)$ & $(0.368)$ & $(0.356)$ & $(0.320)$ \\
\hline \multirow[t]{2}{*}{ Employed } & 0.318 & 0.058 & 0.252 & -0.081 \\
\hline & $(0.402)$ & $(0.416)$ & $(0.439)$ & $(0.391)$ \\
\hline \multicolumn{5}{|l|}{ Income } \\
\hline \multirow[t]{2}{*}{$1,001-2,000$} & 0.752 & 0.111 & 0.831 & 0.652 \\
\hline & $(0.522)$ & $(0.543)$ & $(0.590)$ & $(0.502)$ \\
\hline \multirow[t]{2}{*}{$2,001-2,500$} & -0.248 & 0.120 & 0.715 & $1.189 * *$ \\
\hline & $(0.575)$ & $(0.685)$ & $(0.674)$ & $(0.572)$ \\
\hline \multirow[t]{2}{*}{$2,501-3,000$} & 0.569 & 0.127 & 0.955 & 0.574 \\
\hline & $(0.654)$ & $(0.620)$ & $(0.683)$ & $(0.566)$ \\
\hline \multirow[t]{2}{*}{$3,001-4,000$} & 0.374 & 0.536 & $1.234^{*}$ & $1.226^{* *}$ \\
\hline & $(0.597)$ & $(0.653)$ & $(0.690)$ & $(0.590)$ \\
\hline \multirow[t]{2}{*}{$4,001-7,000$} & $1.393 *$ & 0.736 & $1.543^{* *}$ & $1.919 * * *$ \\
\hline & $(0.732)$ & $(0.855)$ & $(0.774)$ & $(0.707)$ \\
\hline \multirow[t]{2}{*}{ Above 7,000} & -0.141 & 0.583 & 1.241 & 0.157 \\
\hline & (1.003) & (1.116) & $(0.967)$ & $(0.979)$ \\
\hline \multirow[t]{2}{*}{ Real estate owner } & -0.005 & -0.177 & $-0.712 *$ & $-0.631 *$ \\
\hline & $(0.346)$ & $(0.398)$ & $(0.403)$ & $(0.347)$ \\
\hline \multirow[t]{2}{*}{ Financial literacy } & -0.200 & -0.042 & $-0.593 * *$ & -0.032 \\
\hline & $(0.232)$ & $(0.273)$ & $(0.265)$ & $(0.230)$ \\
\hline \multirow[t]{2}{*}{ Bitcoin buyer } & $2.974 * * *$ & $2.935 * * *$ & $2.065 * * *$ & $3.454 * * *$ \\
\hline & $(0.462)$ & $(0.513)$ & $(0.523)$ & $(0.416)$ \\
\hline Best estimate public acceptance & 0.321 & $0.971 * *$ & $1.106^{* * *}$ & $0.768^{* *}$ \\
\hline & $(0.394)$ & $(0.423)$ & $(0.421)$ & $(0.358)$ \\
\hline Overestimate public acceptance & $1.590 * * *$ & $1.481 * * *$ & $1.534 * * *$ & $1.566 * * *$ \\
\hline & $(0.445)$ & $(0.509)$ & $(0.453)$ & $(0.451)$ \\
\hline Best estimate $\mathrm{CO}_{2}$ emissions & -0.144 & -0.401 & -0.080 & -0.120 \\
\hline & $(0.406)$ & $(0.460)$ & $(0.444)$ & $(0.395)$ \\
\hline Overestimate $\mathrm{CO}_{2}$ emissions & 0.118 & -0.450 & -0.248 & -0.488 \\
\hline & $(0.442)$ & $(0.486)$ & $(0.473)$ & $(0.408)$ \\
\hline Best estimate value stolen & 0.640 & 0.237 & 0.157 & 0.370 \\
\hline & $(0.723)$ & $(0.736)$ & $(0.847)$ & $(0.694)$ \\
\hline Overestimate value stolen & -0.151 & 0.715 & 0.827 & 0.466 \\
\hline & $(0.734)$ & $(0.754)$ & $(0.846)$ & $(0.682)$ \\
\hline Constant & -3.288 & -4.300 & -1.948 & -0.342 \\
\hline & $(4.268)$ & $(4.912)$ & $(4.880)$ & $(4.339)$ \\
\hline Observations & 260 & 238 & 253 & 258 \\
\hline R squared & 0.359 & 0.295 & 0.292 & 0.416 \\
\hline Adjusted R squared & 0.294 & 0.215 & 0.218 & 0.356 \\
\hline
\end{tabular}

Notes: The table shows the estimated regression coefficients and robust standard errors for the lowest tertile of the age distribution. Each column shows the estimates of the respective information treatment: (1) official warning, (2) privacy issues, (3) $\mathrm{CO}_{2}$ emissions, and (4) public acceptance. The estimates come from a linear regression of the probability of buying Bitcoin within the next two weeks on the respective treatment indicator, country-fixed effects, and a set of covariates except the one indicating the subgroup considered. The reference value for the country-fixed effects is Germany. The covariates include age, age (squared), female, academic degree, employment, income (6 categories), real estate ownership, financial literacy, Bitcoin experiences, and the answers from the elicitation stage. The reference value for the income groups is the group with an income below $€ 1,000$. To categorize the answers given in the elicitation stage, we placed a $33.3 \%$ band around each of the true values. Answers that lie within the $33.3 \%$ band belong to the "best estimates" group. Answers above this band belong to the "overestimates" group, and answers below this band belong to the "underestimates" group. Here, the "underestimates" group is the reference group. We also experimented with a 50\% bandwidth, but the results did not change significantly. Robust standard errors in parentheses. ${ }^{*} \mathrm{p}<0.10,{ }^{* *} \mathrm{p}<0.05,{ }^{* * *} \mathrm{p}<0.01$. 
Table A.7. Regression Table for High-Age Sample

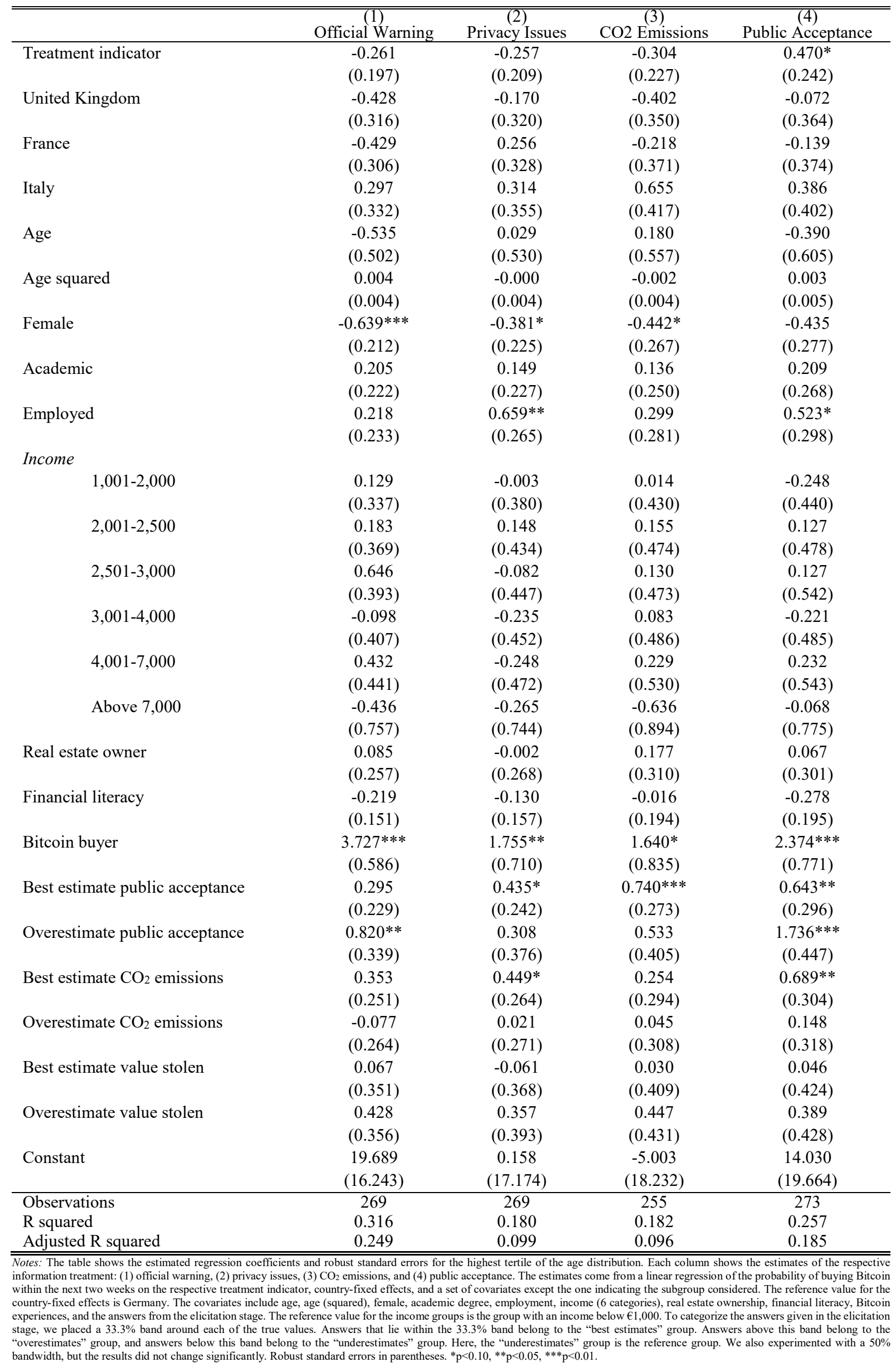


Table A.8. Regression Table for Non-Academic Sample

\begin{tabular}{|c|c|c|c|c|}
\hline & $\begin{array}{c}(1) \\
\text { Official Warning }\end{array}$ & $\begin{array}{c}\text { (2) } \\
\text { Privacy Issues }\end{array}$ & $\begin{array}{c}(3) \\
\mathrm{CO} 2 \text { Emissions } \\
\end{array}$ & $\begin{array}{c}\text { (4) } \\
\text { Public Acceptance }\end{array}$ \\
\hline \multirow[t]{2}{*}{ Treatment indicator } & 0.016 & -0.278 & -0.240 & 0.256 \\
\hline & $(0.197)$ & $(0.199)$ & $(0.202)$ & $(0.199)$ \\
\hline \multirow[t]{2}{*}{ Germany } & 0.000 & 0.000 & 0.000 & 0.000 \\
\hline & (.) & (.) & (.) & (.) \\
\hline \multirow[t]{2}{*}{ United Kingdom } & $-0.614 * *$ & $-0.631 * *$ & $-0.628 * *$ & $-0.561 * *$ \\
\hline & $(0.286)$ & $(0.288)$ & $(0.312)$ & $(0.284)$ \\
\hline \multirow[t]{2}{*}{ France } & -0.413 & -0.333 & $-0.666^{* *}$ & -0.081 \\
\hline & $(0.304)$ & $(0.304)$ & $(0.310)$ & $(0.298)$ \\
\hline \multirow[t]{2}{*}{ Italy } & -0.131 & -0.207 & -0.284 & -0.110 \\
\hline & $(0.307)$ & $(0.311)$ & $(0.336)$ & $(0.324)$ \\
\hline \multirow[t]{2}{*}{ Age } & 0.015 & 0.005 & -0.030 & -0.042 \\
\hline & $(0.043)$ & $(0.045)$ & $(0.047)$ & $(0.044)$ \\
\hline \multirow[t]{2}{*}{ Age squared } & -0.000 & -0.000 & 0.000 & 0.000 \\
\hline & $(0.000)$ & $(0.000)$ & $(0.000)$ & $(0.000)$ \\
\hline \multirow[t]{2}{*}{ Female } & $-0.747 * * *$ & $-0.729 * * *$ & $-0.733 * * *$ & $-0.634 * * *$ \\
\hline & $(0.204)$ & $(0.205)$ & $(0.217)$ & $(0.211)$ \\
\hline \multirow[t]{2}{*}{ Employed } & 0.130 & 0.110 & 0.266 & 0.204 \\
\hline & $(0.239)$ & $(0.237)$ & $(0.256)$ & $(0.244)$ \\
\hline \multicolumn{5}{|l|}{ Income } \\
\hline \multirow[t]{2}{*}{$1,001-2,000$} & 0.300 & 0.247 & 0.365 & 0.273 \\
\hline & $(0.314)$ & $(0.313)$ & $(0.337)$ & $(0.315)$ \\
\hline \multirow[t]{2}{*}{$2,001-2,500$} & 0.416 & $0.762 * *$ & 0.483 & $0.673^{*}$ \\
\hline & $(0.353)$ & $(0.375)$ & $(0.376)$ & $(0.352)$ \\
\hline \multirow[t]{2}{*}{$2,501-3,000$} & $0.982 * *$ & $0.904 * *$ & $0.918^{* *}$ & $0.997 * *$ \\
\hline & $(0.388)$ & $(0.375)$ & $(0.397)$ & $(0.386)$ \\
\hline \multirow[t]{2}{*}{$3,001-4,000$} & -0.027 & 0.005 & 0.615 & 0.194 \\
\hline & $(0.396)$ & $(0.401)$ & $(0.422)$ & $(0.385)$ \\
\hline \multirow[t]{2}{*}{$4,001-7,000$} & 0.324 & 0.353 & 0.438 & 0.351 \\
\hline & $(0.465)$ & $(0.471)$ & $(0.482)$ & $(0.465)$ \\
\hline \multirow[t]{2}{*}{ Above 7,000} & 0.313 & 0.531 & 0.207 & 0.086 \\
\hline & $(0.631)$ & $(0.861)$ & $(0.974)$ & $(0.778)$ \\
\hline \multirow[t]{2}{*}{ Real estate owner } & 0.108 & -0.072 & 0.046 & -0.120 \\
\hline & $(0.226)$ & $(0.229)$ & $(0.247)$ & $(0.230)$ \\
\hline \multirow[t]{2}{*}{ Financial literacy } & $-0.392 * * *$ & -0.233 & $-0.467 * * *$ & $-0.326 * *$ \\
\hline & $(0.143)$ & $(0.144)$ & $(0.154)$ & $(0.144)$ \\
\hline \multirow[t]{2}{*}{ Bitcoin buyer } & $3.218 * * *$ & $2.539 * * *$ & $2.352 * * *$ & $3.422 * * *$ \\
\hline & $(0.352)$ & $(0.367)$ & $(0.380)$ & $(0.342)$ \\
\hline Best estimate public acceptance & $0.637 * * *$ & $0.776 * * *$ & $0.911 * * *$ & $0.763 * * *$ \\
\hline & $(0.236)$ & $(0.229)$ & $(0.240)$ & $(0.227)$ \\
\hline Overestimate public acceptance & $1.576 * * *$ & $1.684 * * *$ & $1.409 * * *$ & $1.559 * * *$ \\
\hline & $(0.293)$ & $(0.304)$ & $(0.305)$ & $(0.316)$ \\
\hline Best estimate $\mathrm{CO}_{2}$ emissions & 0.060 & 0.146 & $0.573^{* *}$ & 0.393 \\
\hline & $(0.256)$ & $(0.252)$ & $(0.261)$ & $(0.252)$ \\
\hline Overestimate $\mathrm{CO}_{2}$ emissions & $-0.473^{*}$ & -0.374 & -0.160 & -0.194 \\
\hline & $(0.265)$ & $(0.264)$ & $(0.282)$ & $(0.265)$ \\
\hline Best estimate value stolen & 0.398 & 0.086 & 0.120 & 0.156 \\
\hline & $(0.374)$ & $(0.386)$ & $(0.398)$ & $(0.393)$ \\
\hline Overestimate value stolen & 0.252 & 0.077 & 0.300 & 0.065 \\
\hline & $(0.377)$ & $(0.399)$ & $(0.406)$ & $(0.392)$ \\
\hline Constant & $2.121 * *$ & $2.273^{* *}$ & $2.679 * *$ & $2.737 * *$ \\
\hline & $(1.054)$ & $(1.067)$ & $(1.133)$ & $(1.109)$ \\
\hline Observations & 471 & 469 & 466 & 517 \\
\hline R squared & 0.369 & 0.299 & 0.285 & 0.342 \\
\hline Adjusted R squared & 0.336 & 0.262 & 0.248 & 0.311 \\
\hline
\end{tabular}


Table A.9. Regression Table for Academic Sample

\begin{tabular}{|c|c|c|c|c|}
\hline & $\begin{array}{c}(1) \\
\text { Official Warning }\end{array}$ & $\begin{array}{c}(2) \\
\text { Privacy Issues } \\
\end{array}$ & $\begin{array}{c}(3) \\
\mathrm{CO} 2 \text { Emissions }\end{array}$ & $\begin{array}{c}\text { (4) } \\
\text { Public Acceptance }\end{array}$ \\
\hline \multirow[t]{2}{*}{ Treatment indicator } & $-0.448^{*}$ & $-0.589 * *$ & -0.210 & $0.449 *$ \\
\hline & $(0.253)$ & $(0.240)$ & $(0.262)$ & $(0.264)$ \\
\hline \multirow[t]{2}{*}{ United Kingdom } & -0.338 & -0.339 & 0.017 & -0.228 \\
\hline & $(0.402)$ & $(0.377)$ & $(0.442)$ & $(0.421)$ \\
\hline \multirow[t]{2}{*}{ France } & -0.069 & -0.157 & 0.321 & -0.581 \\
\hline & $(0.408)$ & $(0.387)$ & $(0.471)$ & $(0.434)$ \\
\hline \multirow[t]{2}{*}{ Italy } & 0.596 & 0.203 & 0.760 & 0.712 \\
\hline & $(0.454)$ & $(0.426)$ & $(0.498)$ & $(0.461)$ \\
\hline \multirow[t]{2}{*}{ Age } & 0.004 & 0.000 & 0.068 & $0.139^{*}$ \\
\hline & $(0.069)$ & $(0.066)$ & $(0.074)$ & $(0.071)$ \\
\hline \multirow[t]{2}{*}{ Age squared } & -0.000 & -0.000 & -0.001 & $-0.002 * *$ \\
\hline & $(0.001)$ & $(0.001)$ & $(0.001)$ & $(0.001)$ \\
\hline \multirow[t]{2}{*}{ Female } & -0.381 & -0.343 & -0.439 & $-0.516^{*}$ \\
\hline & $(0.283)$ & $(0.256)$ & $(0.289)$ & $(0.302)$ \\
\hline \multirow[t]{2}{*}{ Employed } & 0.209 & 0.436 & 0.235 & -0.089 \\
\hline & $(0.350)$ & $(0.331)$ & $(0.374)$ & $(0.371)$ \\
\hline \multirow[t]{2}{*}{ Below 1,000 } & 0.000 & 0.000 & 0.000 & 0.000 \\
\hline & (.) & (.) & (.) & (.) \\
\hline \multirow[t]{2}{*}{$1,001-2,000$} & 0.206 & -0.012 & 0.378 & 0.447 \\
\hline & $(0.550)$ & $(0.503)$ & $(0.603)$ & $(0.571)$ \\
\hline \multirow[t]{2}{*}{$2,001-2,500$} & 0.401 & 0.272 & 0.613 & 1.022 \\
\hline & $(0.615)$ & $(0.593)$ & $(0.710)$ & $(0.645)$ \\
\hline \multirow[t]{2}{*}{$2,501-3,000$} & 0.726 & 0.365 & 0.874 & $1.206^{*}$ \\
\hline & $(0.600)$ & $(0.541)$ & $(0.647)$ & $(0.615)$ \\
\hline \multirow[t]{2}{*}{$3,001-4,000$} & $0.977^{*}$ & 0.716 & $1.077^{*}$ & $1.934 * * *$ \\
\hline & $(0.576)$ & $(0.535)$ & $(0.637)$ & $(0.599)$ \\
\hline \multirow[t]{2}{*}{$4,001-7,000$} & $1.037^{*}$ & 0.194 & $1.095^{*}$ & $2.214 * * *$ \\
\hline & $(0.604)$ & $(0.558)$ & $(0.651)$ & $(0.641)$ \\
\hline \multirow[t]{2}{*}{ Above 7,000 } & -0.217 & 0.475 & 0.440 & 1.221 \\
\hline & $(0.854)$ & $(0.765)$ & $(0.867)$ & $(0.832)$ \\
\hline \multirow[t]{2}{*}{ Real estate owner } & -0.210 & -0.066 & $-0.695 * *$ & $-0.570^{*}$ \\
\hline & $(0.297)$ & $(0.297)$ & $(0.330)$ & $(0.322)$ \\
\hline \multirow[t]{2}{*}{ Financial literacy } & 0.115 & 0.031 & 0.106 & -0.150 \\
\hline & $(0.199)$ & $(0.195)$ & $(0.213)$ & $(0.211)$ \\
\hline \multirow[t]{2}{*}{ Bitcoin buyer } & $3.774 * * *$ & $3.712 * * *$ & $2.788 * * *$ & $2.863 * * *$ \\
\hline & $(0.416)$ & $(0.434)$ & $(0.455)$ & $(0.401)$ \\
\hline \multirow[t]{2}{*}{ Best estimate public acceptance } & 0.387 & 0.448 & $1.001 * * *$ & $0.555^{*}$ \\
\hline & $(0.312)$ & $(0.303)$ & $(0.349)$ & $(0.336)$ \\
\hline \multirow[t]{2}{*}{ Overestimate public acceptance } & $1.038 * * *$ & 0.274 & $1.403 * * *$ & $0.932 * *$ \\
\hline & $(0.398)$ & $(0.396)$ & $(0.404)$ & $(0.404)$ \\
\hline Best estimate $\mathrm{CO}_{2}$ emissions & -0.164 & -0.036 & -0.467 & 0.081 \\
\hline & $(0.330)$ & $(0.320)$ & $(0.346)$ & $(0.340)$ \\
\hline Overestimate $\mathrm{CO}_{2}$ emissions & -0.048 & -0.162 & -0.422 & -0.120 \\
\hline & $(0.346)$ & $(0.334)$ & $(0.355)$ & $(0.338)$ \\
\hline Best estimate value stolen & -0.160 & -0.166 & 0.140 & -0.069 \\
\hline & $(0.497)$ & $(0.440)$ & $(0.526)$ & $(0.505)$ \\
\hline Overestimate value stolen & -0.160 & 0.592 & $1.026^{*}$ & 0.650 \\
\hline & $(0.504)$ & $(0.451)$ & $(0.531)$ & $(0.501)$ \\
\hline Constant & 1.383 & 1.544 & -0.509 & -1.489 \\
\hline & $(1.618)$ & $(1.534)$ & $(1.691)$ & $(1.720)$ \\
\hline Observations & 311 & 327 & 310 & 324 \\
\hline R squared & 0.426 & 0.378 & 0.374 & 0.433 \\
\hline Adjusted R squared & 0.379 & 0.331 & 0.324 & 0.390 \\
\hline
\end{tabular}


Table A.10. Regression Table for Bitcoin Non-Buyer Sample

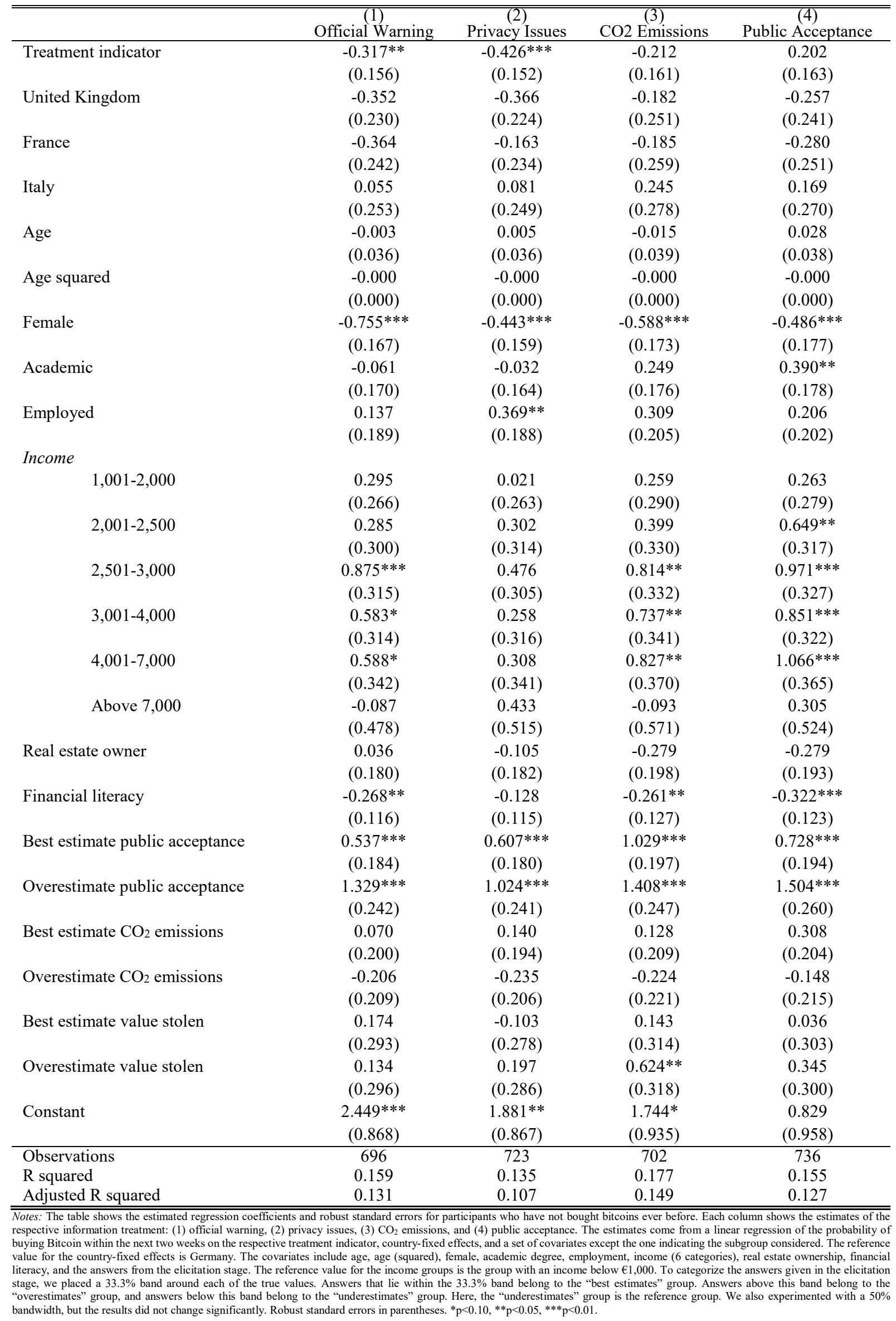


Table A.11. Regression Table for Bitcoin Buyer Sample

\begin{tabular}{|c|c|c|c|c|}
\hline & $\begin{array}{c}\text { (1) } \\
\text { Official Warning }\end{array}$ & $\begin{array}{c}(2) \\
\text { Privacy Issues }\end{array}$ & $\begin{array}{c}\text { (3) } \\
\text { CO2 Emissions }\end{array}$ & $\begin{array}{c}\text { Public Acceptance } \\
\text { Pac }\end{array}$ \\
\hline \multirow[t]{2}{*}{ Treatment indicator } & $1.439 * *$ & 0.430 & -0.327 & $1.250^{* *}$ \\
\hline & $(0.713)$ & $(0.796)$ & $(0.829)$ & $(0.610)$ \\
\hline \multirow[t]{2}{*}{ United Kingdom } & -1.811 & $-3.764 * * *$ & $-2.375^{*}$ & $-2.541 * * *$ \\
\hline & $(1.089)$ & $(1.195)$ & $(1.321)$ & $(0.903)$ \\
\hline \multirow[t]{2}{*}{ France } & 0.373 & -1.268 & -1.749 & -1.078 \\
\hline & $(1.102)$ & (1.195) & $(1.328)$ & $(0.910)$ \\
\hline \multirow[t]{2}{*}{ Italy } & 0.316 & -1.483 & -0.078 & 0.469 \\
\hline & $(1.277)$ & $(1.196)$ & $(1.296)$ & $(0.944)$ \\
\hline \multirow[t]{2}{*}{ Age } & 0.264 & 0.043 & $0.602 * *$ & -0.032 \\
\hline & $(0.247)$ & $(0.250)$ & $(0.279)$ & $(0.171)$ \\
\hline \multirow[t]{2}{*}{ Age squared } & -0.004 & -0.001 & $-0.008 * *$ & -0.001 \\
\hline & $(0.003)$ & $(0.003)$ & $(0.003)$ & $(0.002)$ \\
\hline \multirow[t]{2}{*}{ Female } & -0.243 & $-1.803^{* *}$ & -0.919 & $-1.582 * *$ \\
\hline & $(0.712)$ & $(0.858)$ & $(0.894)$ & $(0.656)$ \\
\hline \multirow[t]{2}{*}{ Academic } & 0.285 & $2.017 * *$ & $1.806^{*}$ & -0.734 \\
\hline & $(0.923)$ & $(0.875)$ & $(0.931)$ & $(0.671)$ \\
\hline \multirow[t]{2}{*}{ Employed } & -1.848 & -0.822 & -3.095 & -0.414 \\
\hline & (1.991) & (1.183) & $(2.243)$ & (1.068) \\
\hline \multicolumn{5}{|l|}{ Income } \\
\hline \multirow[t]{2}{*}{$1,001-2,000$} & 0.843 & 1.020 & $3.785^{*}$ & 1.295 \\
\hline & $(1.702)$ & $(1.516)$ & (1.914) & $(1.324)$ \\
\hline \multirow[t]{2}{*}{$2,001-2,500$} & 2.545 & $3.633 * *$ & $4.129^{*}$ & $2.652 * *$ \\
\hline & $(1.844)$ & $(1.792)$ & $(2.098)$ & $(1.267)$ \\
\hline \multirow[t]{2}{*}{$2,501-3,000$} & 1.456 & 1.764 & $3.991 * *$ & $2.610^{*}$ \\
\hline & $(1.782)$ & $(1.494)$ & $(1.931)$ & $(1.391)$ \\
\hline \multirow[t]{2}{*}{$3,001-4,000$} & 1.166 & 2.064 & $4.784 * *$ & $3.316^{* *}$ \\
\hline & $(1.761)$ & $(1.327)$ & $(1.932)$ & $(1.344)$ \\
\hline \multirow[t]{2}{*}{$4,001-7,000$} & 2.838 & 0.549 & 2.983 & $3.246 * *$ \\
\hline & $(1.901)$ & $(1.589)$ & $(1.890)$ & $(1.457)$ \\
\hline \multirow[t]{2}{*}{ Above 7,000} & 2.331 & & $7.446^{* *}$ & $9.661 * * *$ \\
\hline & $(3.943)$ & & $(3.675)$ & $(3.132)$ \\
\hline \multirow[t]{2}{*}{ Real estate owner } & -0.580 & 0.697 & -0.086 & 0.042 \\
\hline & $(0.768)$ & $(0.856)$ & $(0.957)$ & $(0.666)$ \\
\hline \multirow[t]{2}{*}{ Financial literacy } & 0.257 & -0.145 & -0.414 & $0.833 * *$ \\
\hline & $(0.564)$ & $(0.592)$ & $(0.583)$ & $(0.413)$ \\
\hline \multirow[t]{2}{*}{ Best estimate public acceptance } & 0.594 & 0.935 & -0.470 & 0.881 \\
\hline & $(1.107)$ & $(0.983)$ & $(1.097)$ & $(0.734)$ \\
\hline \multirow[t]{2}{*}{ Overestimate public acceptance } & 1.430 & 1.579 & 0.722 & 0.885 \\
\hline & $(0.932)$ & $(1.131)$ & $(1.094)$ & $(0.853)$ \\
\hline Best estimate $\mathrm{CO}_{2}$ emissions & $-1.754 *$ & -1.139 & 0.065 & 0.097 \\
\hline & $(0.967)$ & $(1.143)$ & $(1.102)$ & $(0.903)$ \\
\hline Overestimate $\mathrm{CO}_{2}$ emissions & -1.663 & -0.724 & -1.112 & -0.830 \\
\hline & $(1.015)$ & $(1.014)$ & $(1.062)$ & $(0.823)$ \\
\hline Best estimate value stolen & 0.630 & 4.224 & -0.989 & 1.013 \\
\hline & $(1.721)$ & $(3.379)$ & $(2.102)$ & $(2.948)$ \\
\hline Overestimate value stolen & 1.280 & 5.126 & -0.514 & 1.952 \\
\hline & $(1.683)$ & (3.349) & $(2.099)$ & (2.949) \\
\hline Constant & 0.097 & 0.083 & -4.745 & 3.839 \\
\hline & $(5.113)$ & $(6.336)$ & $(5.805)$ & $(4.679)$ \\
\hline Observations & 86 & 73 & 74 & 105 \\
\hline $\mathrm{R}$ squared & 0.269 & 0.436 & 0.329 & 0.369 \\
\hline Adjusted R squared & -0.003 & 0.188 & 0.020 & 0.190 \\
\hline $\begin{array}{l}\text { otes: The table shows the estimated regression co } \\
\text { formation treatment: (1) official warning, (2) priva } \\
\text { ithin the next two weeks on the respective treatme } \\
\text { onntry-fixed effects is Germany. The covariates in } \\
\text { uswers from the elicitation stage. The reference va } \\
3.3 \% \text { band around each of the true values. Answer } \\
\text { aswers below this band belong to the "underestima } \\
\text { hange significantly. Robust standard errors in pare }\end{array}$ & 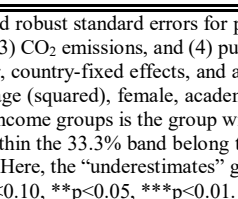 & $\begin{array}{l}\text { ants who have boug } \\
\text { ceptance. The estima }\end{array}$ & $\begin{array}{l}\text { oins before. Each column } \\
\text { me from a linear regressi } \\
\text { indicating the subgroup c } \\
\text { ( } 6 \text { categories), real estate } \\
\text { ategorize the answers giv } \\
\text { swers above this band bel }\end{array}$ & $\begin{array}{l}\text { v the estimates of the respect } \\
\text { the probability of buying Bitc } \\
\text { ered. The reference value for } \\
\text { ership, financial literacy, and } \\
\text { the elicitation stage, we place } \\
\text { o the "overestimates" group, } \\
\text { bandwidth but the results did }\end{array}$ \\
\hline
\end{tabular}


Table A.12. Regression Table for Low-Income Sample

\begin{tabular}{|c|c|c|c|c|}
\hline & $\begin{array}{c}(1) \\
\text { Official Warning }\end{array}$ & $\begin{array}{c}(2) \\
\text { Privacy Issues }\end{array}$ & $\begin{array}{c}\text { (3) } \\
\mathrm{CO} 2 \text { Emissions }\end{array}$ & $\begin{array}{c}(4) \\
\text { Public Acceptance }\end{array}$ \\
\hline \multirow[t]{2}{*}{ Treatment indicator } & 0.170 & -0.087 & 0.144 & 0.294 \\
\hline & $(0.246)$ & $(0.230)$ & $(0.247)$ & $(0.246)$ \\
\hline \multirow[t]{2}{*}{ United Kingdom } & -0.127 & -0.157 & 0.146 & -0.178 \\
\hline & $(0.364)$ & $(0.343)$ & $(0.402)$ & $(0.364)$ \\
\hline \multirow[t]{2}{*}{ France } & -0.253 & -0.012 & -0.187 & -0.445 \\
\hline & $(0.409)$ & $(0.375)$ & $(0.420)$ & $(0.418)$ \\
\hline \multirow[t]{2}{*}{ Italy } & 0.128 & -0.027 & 0.629 & 0.267 \\
\hline & $(0.407)$ & $(0.374)$ & $(0.430)$ & $(0.420)$ \\
\hline \multirow[t]{2}{*}{ Age } & -0.040 & -0.049 & -0.059 & -0.034 \\
\hline & $(0.053)$ & $(0.050)$ & $(0.054)$ & $(0.051)$ \\
\hline \multirow[t]{2}{*}{ Age squared } & 0.000 & 0.000 & 0.000 & 0.000 \\
\hline & $(0.001)$ & $(0.001)$ & $(0.001)$ & $(0.001)$ \\
\hline \multirow[t]{2}{*}{ Female } & -0.315 & $-0.537 * *$ & $-0.549 * *$ & $-0.496^{*}$ \\
\hline & $(0.267)$ & $(0.239)$ & $(0.269)$ & $(0.272)$ \\
\hline \multirow[t]{2}{*}{ Academic } & -0.358 & -0.206 & 0.107 & -0.222 \\
\hline & $(0.282)$ & $(0.256)$ & $(0.280)$ & $(0.283)$ \\
\hline \multirow[t]{2}{*}{ Employed } & -0.055 & 0.234 & 0.143 & -0.151 \\
\hline & $(0.266)$ & $(0.253)$ & $(0.281)$ & $(0.266)$ \\
\hline \multirow[t]{2}{*}{ Real estate owner } & 0.324 & 0.181 & -0.005 & -0.152 \\
\hline & $(0.279)$ & $(0.274)$ & $(0.286)$ & $(0.289)$ \\
\hline \multirow[t]{2}{*}{ Financial literacy } & -0.182 & 0.011 & -0.107 & -0.169 \\
\hline & $(0.181)$ & $(0.178)$ & $(0.203)$ & $(0.191)$ \\
\hline \multirow[t]{2}{*}{ Bitcoin buyer } & $3.349 * * *$ & $2.125 * * *$ & $2.191 * * *$ & $2.707 * * *$ \\
\hline & $(0.484)$ & $(0.475)$ & $(0.532)$ & $(0.453)$ \\
\hline \multirow[t]{2}{*}{ Best estimate public acceptance } & $0.607 * *$ & $0.507^{*}$ & $1.012 * * *$ & 0.180 \\
\hline & $(0.289)$ & $(0.278)$ & $(0.307)$ & $(0.282)$ \\
\hline \multirow[t]{2}{*}{ Overestimate public acceptance } & $0.962 * * *$ & $1.097 * * *$ & $0.910 * *$ & $1.013 * * *$ \\
\hline & $(0.365)$ & $(0.351)$ & $(0.374)$ & $(0.380)$ \\
\hline \multirow[t]{2}{*}{ Best estimate $\mathrm{CO}_{2}$ emissions } & 0.104 & 0.129 & 0.074 & 0.454 \\
\hline & $(0.321)$ & $(0.302)$ & $(0.329)$ & $(0.315)$ \\
\hline \multirow[t]{2}{*}{ Overestimate $\mathrm{CO}_{2}$ emissions } & -0.158 & -0.045 & -0.417 & 0.118 \\
\hline & $(0.335)$ & $(0.326)$ & $(0.348)$ & $(0.330)$ \\
\hline \multirow[t]{2}{*}{ Best estimate value stolen } & 0.180 & -0.133 & 0.233 & -0.290 \\
\hline & $(0.496)$ & $(0.419)$ & $(0.447)$ & $(0.464)$ \\
\hline \multirow[t]{2}{*}{ Overestimate value stolen } & -0.075 & 0.017 & 0.597 & 0.103 \\
\hline & $(0.514)$ & $(0.439)$ & $(0.453)$ & $(0.464)$ \\
\hline \multirow[t]{2}{*}{ Constant } & $2.984 * *$ & $2.843^{* *}$ & $2.490^{*}$ & $2.871 * *$ \\
\hline & $(1.246)$ & $(1.172)$ & $(1.313)$ & $(1.284)$ \\
\hline Observations & 307 & 314 & 296 & 317 \\
\hline R squared & 0.311 & 0.197 & 0.230 & 0.237 \\
\hline Adjusted R squared & 0.268 & 0.148 & 0.179 & 0.191 \\
\hline \multicolumn{5}{|c|}{ 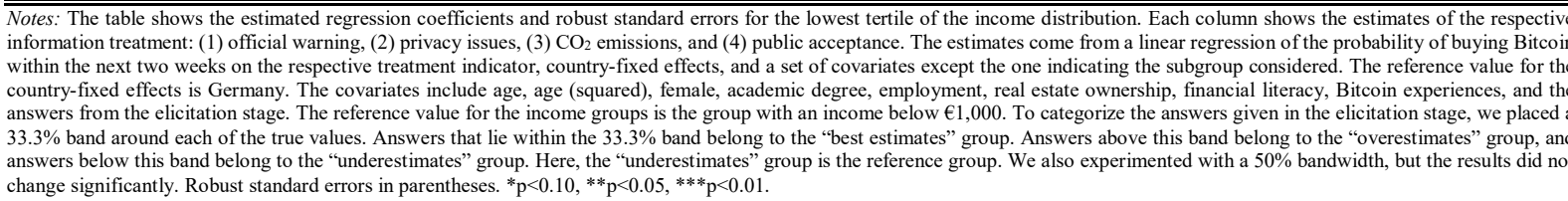 } \\
\hline
\end{tabular}


Table A.13. Regression Table for High-Income Sample

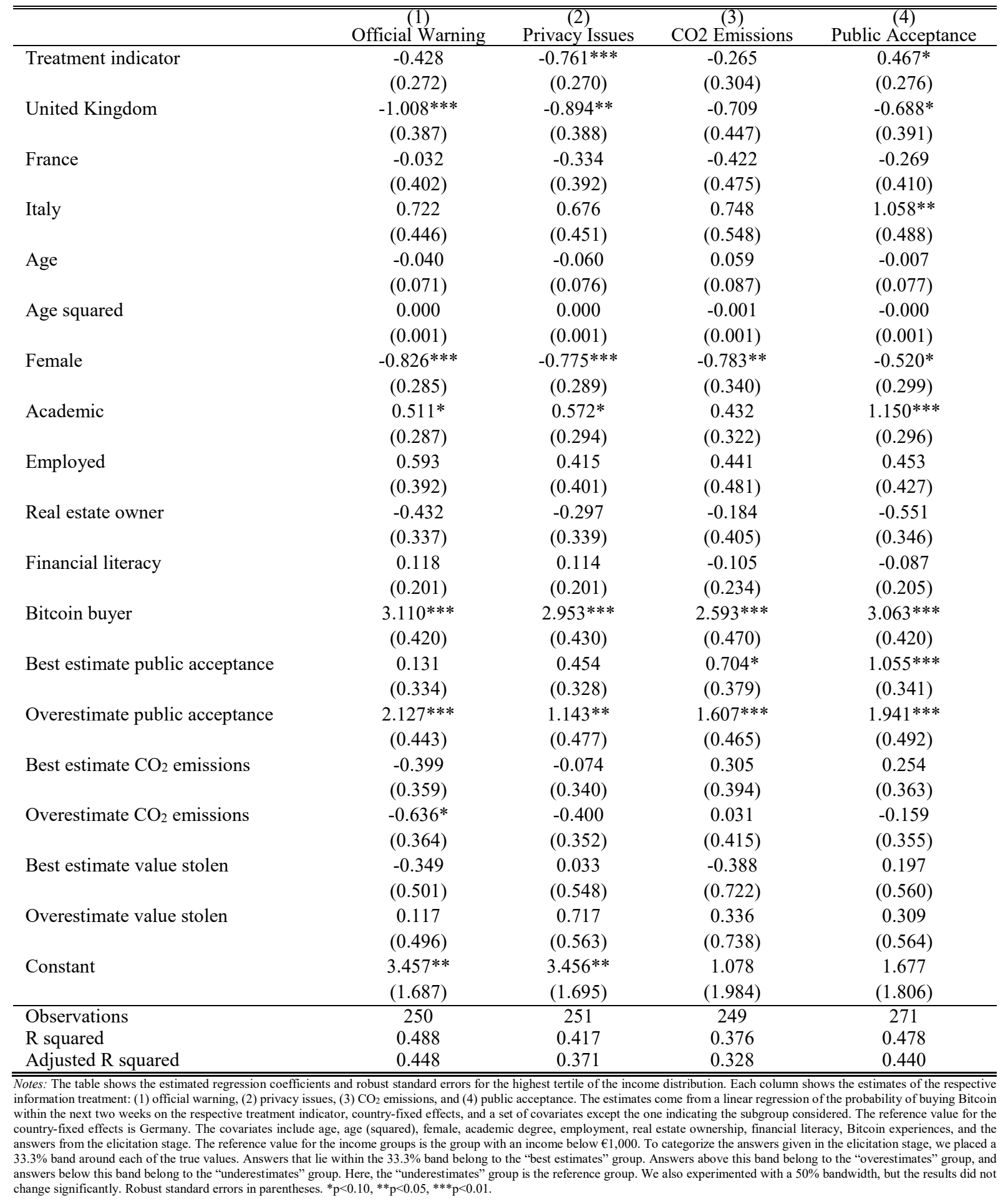


Table A.14. Regression Table for Real Estate Non-Owner Sample

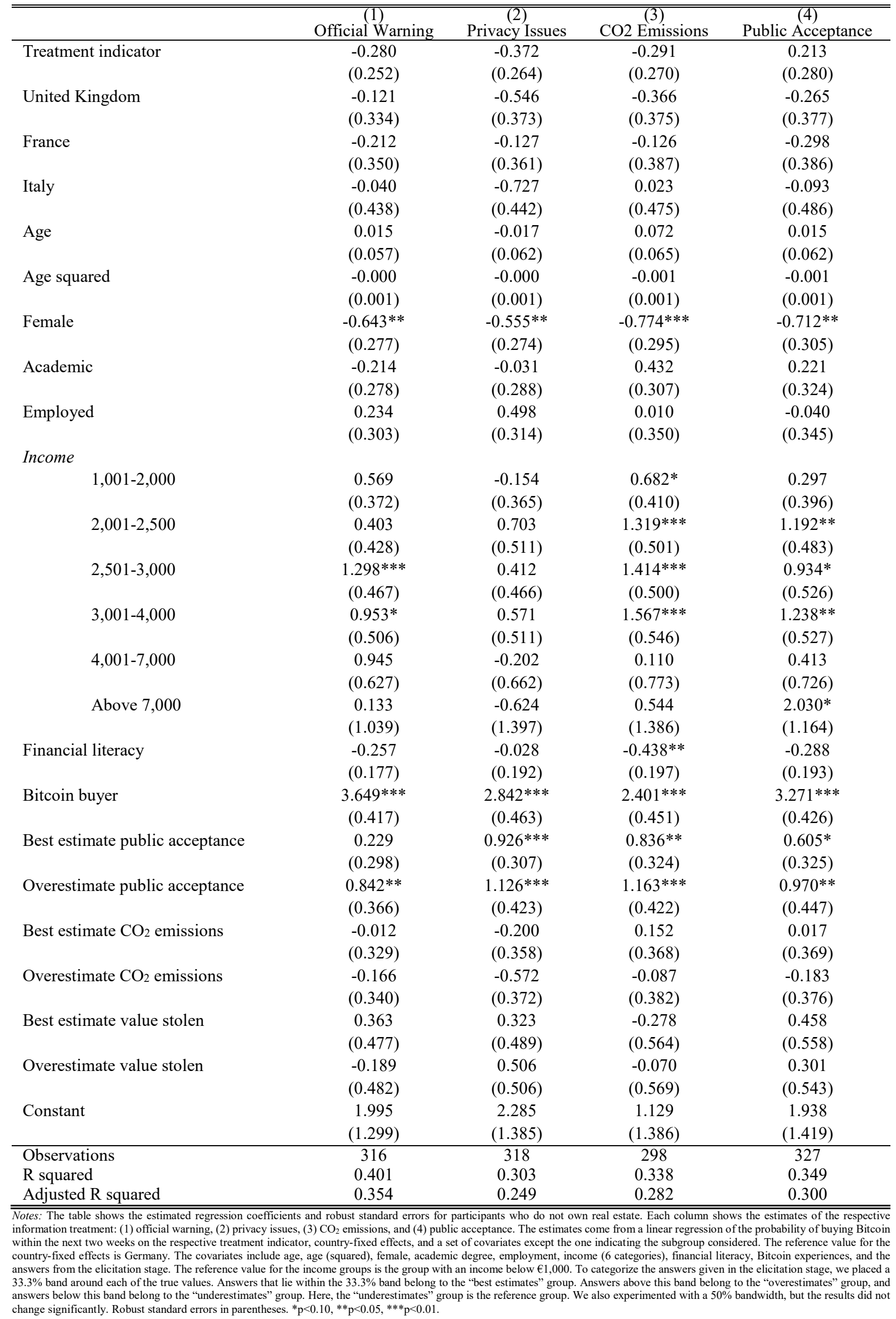


Table A.15. Regression Table for Real Estate Owner Sample

\begin{tabular}{|c|c|c|c|c|}
\hline & $\begin{array}{c}\text { (1) } \\
\text { Official Warning }\end{array}$ & $\begin{array}{c}\text { (2) } \\
\text { Privacy Issues }\end{array}$ & $\begin{array}{c}(3) \\
\mathrm{CO} 2 \text { Emissions } \\
\end{array}$ & $\begin{array}{c}\text { (4) } \\
\text { Public Acceptance }\end{array}$ \\
\hline \multirow[t]{2}{*}{ Treatment indicator } & -0.087 & $-0.423 * *$ & -0.231 & 0.318 \\
\hline & $(0.201)$ & $(0.188)$ & $(0.197)$ & $(0.196)$ \\
\hline \multirow[t]{2}{*}{ United Kingdom } & $-0.847 * *$ & -0.486 & -0.543 & $-0.555^{*}$ \\
\hline & $(0.341)$ & $(0.309)$ & $(0.367)$ & $(0.326)$ \\
\hline \multirow[t]{2}{*}{ France } & -0.391 & -0.369 & -0.380 & -0.304 \\
\hline & $(0.351)$ & $(0.331)$ & $(0.373)$ & $(0.340)$ \\
\hline \multirow[t]{2}{*}{ Italy } & 0.037 & 0.166 & 0.174 & 0.286 \\
\hline & $(0.343)$ & $(0.328)$ & $(0.373)$ & $(0.342)$ \\
\hline \multirow[t]{2}{*}{ Age } & 0.013 & 0.037 & -0.006 & 0.044 \\
\hline & $(0.051)$ & $(0.048)$ & $(0.053)$ & $(0.050)$ \\
\hline \multirow[t]{2}{*}{ Age squared } & -0.000 & -0.001 & -0.000 & -0.001 \\
\hline & $(0.001)$ & $(0.001)$ & $(0.001)$ & $(0.001)$ \\
\hline \multirow[t]{2}{*}{ Female } & $-0.681 * * *$ & $-0.611 * * *$ & $-0.493 * *$ & $-0.510 * *$ \\
\hline & $(0.211)$ & $(0.198)$ & $(0.214)$ & $(0.211)$ \\
\hline \multirow[t]{2}{*}{ Academic } & 0.110 & 0.198 & 0.191 & $0.361^{*}$ \\
\hline & $(0.221)$ & $(0.203)$ & $(0.216)$ & $(0.207)$ \\
\hline \multirow[t]{2}{*}{ Employed } & 0.077 & 0.080 & 0.355 & 0.296 \\
\hline & $(0.262)$ & $(0.249)$ & $(0.269)$ & $(0.258)$ \\
\hline \multicolumn{5}{|l|}{ Income } \\
\hline \multirow[t]{2}{*}{$1,001-2,000$} & -0.122 & 0.471 & -0.336 & 0.361 \\
\hline & $(0.426)$ & $(0.427)$ & $(0.459)$ & $(0.435)$ \\
\hline \multirow[t]{2}{*}{$2,001-2,500$} & 0.092 & 0.637 & -0.374 & 0.673 \\
\hline & $(0.463)$ & $(0.458)$ & $(0.489)$ & $(0.457)$ \\
\hline \multirow[t]{2}{*}{$2,501-3,000$} & 0.298 & $0.977 * *$ & 0.157 & $1.119^{* *}$ \\
\hline & $(0.468)$ & $(0.452)$ & $(0.490)$ & $(0.460)$ \\
\hline \multirow[t]{2}{*}{$3,001-4,000$} & -0.122 & 0.572 & 0.098 & $0.823 *$ \\
\hline & $(0.450)$ & $(0.452)$ & $(0.489)$ & $(0.451)$ \\
\hline \multirow[t]{2}{*}{$4,001-7,000$} & 0.343 & 0.743 & 0.329 & $1.254 * * *$ \\
\hline & $(0.474)$ & $(0.463)$ & $(0.489)$ & $(0.475)$ \\
\hline \multirow[t]{2}{*}{ Above 7,000} & -0.395 & 0.967 & -0.346 & 0.160 \\
\hline & $(0.614)$ & $(0.632)$ & $(0.685)$ & $(0.644)$ \\
\hline \multirow[t]{2}{*}{ Financial literacy } & -0.187 & -0.231 & -0.128 & -0.122 \\
\hline & $(0.154)$ & $(0.148)$ & $(0.164)$ & $(0.155)$ \\
\hline \multirow[t]{2}{*}{ Bitcoin buyer } & $3.309 * * *$ & $3.080 * * *$ & $2.865^{* * *}$ & $3.150 * * *$ \\
\hline & $(0.351)$ & $(0.353)$ & $(0.381)$ & $(0.328)$ \\
\hline \multirow[t]{2}{*}{ Best estimate public acceptance } & $0.710^{* * *}$ & $0.544 * *$ & $1.063^{* * *}$ & $0.807 * * *$ \\
\hline & $(0.241)$ & $(0.228)$ & $(0.247)$ & $(0.236)$ \\
\hline \multirow[t]{2}{*}{ Overestimate public acceptance } & $1.769 * * *$ & $1.113 * * *$ & $1.418 * * *$ & $1.475 * * *$ \\
\hline & $(0.307)$ & $(0.290)$ & $(0.294)$ & $(0.299)$ \\
\hline Best estimate $\mathrm{CO}_{2}$ emissions & -0.225 & 0.130 & 0.090 & $0.432 *$ \\
\hline & $(0.257)$ & $(0.240)$ & $(0.252)$ & $(0.244)$ \\
\hline Overestimate $\mathrm{CO}_{2}$ emissions & $-0.452 *$ & -0.165 & -0.436 & -0.036 \\
\hline & $(0.267)$ & $(0.251)$ & $(0.272)$ & $(0.255)$ \\
\hline Best estimate value stolen & 0.101 & -0.282 & 0.207 & -0.130 \\
\hline & $(0.383)$ & $(0.364)$ & $(0.391)$ & $(0.375)$ \\
\hline Overestimate value stolen & 0.456 & 0.187 & $0.849 * *$ & 0.410 \\
\hline & $(0.386)$ & $(0.372)$ & $(0.392)$ & $(0.378)$ \\
\hline Constant & 2.112 & 1.080 & 1.446 & -0.456 \\
\hline & $(1.283)$ & $(1.248)$ & $(1.413)$ & $(1.366)$ \\
\hline Observations & 466 & 478 & 478 & 514 \\
\hline R squared & 0.386 & 0.337 & 0.315 & 0.390 \\
\hline Adjusted R squared & 0.354 & 0.303 & 0.280 & 0.362 \\
\hline $\begin{array}{l}\text { effects is Germany. The covariates include a } \\
\text { the elicitation stage. The reference value for } t \\
\text { around each of the true values. Answers that } \\
\text { w this band belong to the "underestimates" gro } \\
\text { ficantly. Robust standard errors in parentheses }\end{array}$ & $\begin{array}{l}\text { underestimates" group is } \\
0.05, * * * p<0.01 \text {. }\end{array}$ & nates" group. Answ & $\begin{array}{l}\text { the subgroup considered } \\
\text { tries), financial literacy, } \\
\text { the answers given in th } \\
\text { ve this band belong to tl }\end{array}$ & $\begin{array}{l}\text { ates of the respective informatio } \\
\text { lity of buying Bitcoin within the } \\
\text { reference value for the countr } \\
\text { oin experiences, and the answe } \\
\text { itation stage, we placed a } 33.3^{\circ} \\
\text { erestimates" group, and answer } \\
\text { th, but the results did not chang }\end{array}$ \\
\hline
\end{tabular}


Table A.16. Regression Table for Low Financial Literacy Sample

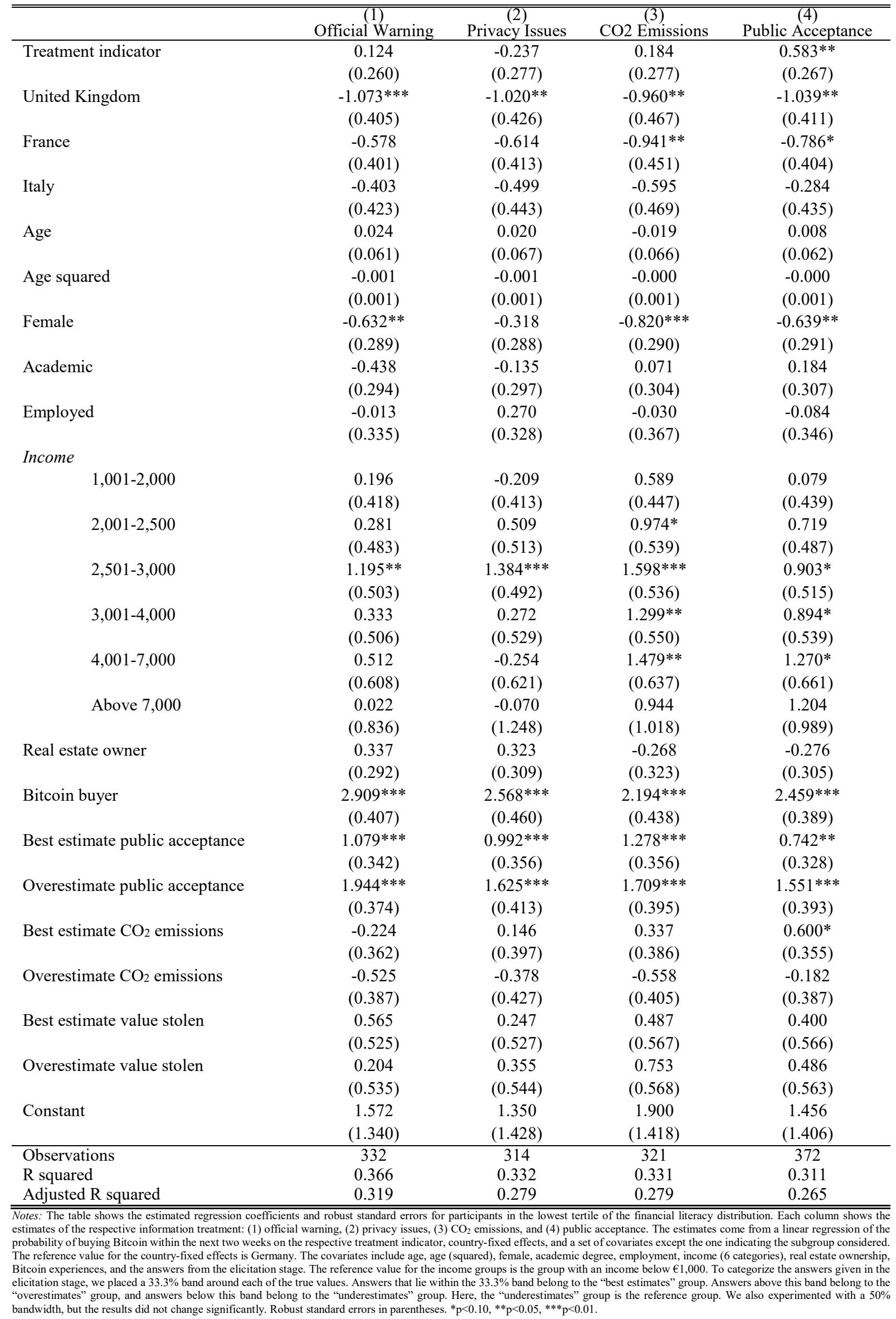


Table A.17. Regression Table for High Financial Literacy Sample

\begin{tabular}{|c|c|c|c|c|}
\hline & $\begin{array}{c}\text { (1) } \\
\text { Official Warning }\end{array}$ & $\begin{array}{c}\text { (2) } \\
\text { Privacy Issues }\end{array}$ & $\begin{array}{c}(3) \\
\mathrm{CO} 2 \text { Emissions } \\
\end{array}$ & $\begin{array}{c}\text { (4) } \\
\text { Public Acceptance }\end{array}$ \\
\hline \multirow[t]{2}{*}{ Treatment indicator } & $-0.559^{*}$ & $-0.773 * *$ & -0.526 & -0.003 \\
\hline & $(0.324)$ & $(0.297)$ & $(0.364)$ & $(0.347)$ \\
\hline \multirow[t]{2}{*}{ United Kingdom } & -0.206 & -0.480 & -0.339 & -0.323 \\
\hline & $(0.407)$ & $(0.381)$ & $(0.473)$ & $(0.411)$ \\
\hline \multirow[t]{2}{*}{ France } & 0.900 & 0.475 & 1.315 & $1.477^{*}$ \\
\hline & $(0.762)$ & $(0.826)$ & $(0.862)$ & $(0.765)$ \\
\hline \multirow[t]{2}{*}{ Italy } & 1.013 & -0.168 & 0.503 & 0.432 \\
\hline & $(0.652)$ & $(0.710)$ & $(0.795)$ & $(0.816)$ \\
\hline \multirow[t]{2}{*}{ Age } & -0.075 & $-0.228 * *$ & 0.039 & -0.026 \\
\hline & $(0.079)$ & $(0.092)$ & $(0.111)$ & $(0.086)$ \\
\hline \multirow[t]{2}{*}{ Age squared } & 0.000 & $0.002 *$ & -0.001 & -0.000 \\
\hline & $(0.001)$ & $(0.001)$ & $(0.001)$ & $(0.001)$ \\
\hline \multirow[t]{2}{*}{ Female } & $-0.989 * * *$ & $-0.656 * *$ & -0.238 & $-0.946 * *$ \\
\hline & $(0.331)$ & $(0.297)$ & $(0.389)$ & $(0.381)$ \\
\hline \multirow[t]{2}{*}{ Academic } & 0.332 & 0.102 & 0.372 & $0.857 * *$ \\
\hline & $(0.350)$ & $(0.333)$ & $(0.398)$ & $(0.378)$ \\
\hline \multirow[t]{2}{*}{ Employed } & 0.073 & -0.493 & -0.209 & 0.039 \\
\hline & $(0.380)$ & $(0.399)$ & $(0.507)$ & $(0.462)$ \\
\hline \multicolumn{5}{|l|}{ Income } \\
\hline \multirow[t]{2}{*}{$1,001-2,000$} & 0.598 & 0.563 & 0.800 & 0.288 \\
\hline & $(0.616)$ & $(0.580)$ & $(0.707)$ & $(0.615)$ \\
\hline \multirow[t]{2}{*}{$2,001-2,500$} & 0.457 & 0.683 & 0.936 & 0.600 \\
\hline & $(0.677)$ & $(0.690)$ & $(0.790)$ & $(0.691)$ \\
\hline \multirow[t]{2}{*}{$2,501-3,000$} & $1.206^{*}$ & 1.077 & $1.676^{* *}$ & 0.583 \\
\hline & $(0.705)$ & $(0.672)$ & $(0.795)$ & $(0.783)$ \\
\hline \multirow[t]{2}{*}{$3,001-4,000$} & 0.774 & 0.949 & $1.450^{*}$ & 0.373 \\
\hline & $(0.724)$ & $(0.655)$ & $(0.765)$ & $(0.662)$ \\
\hline \multirow[t]{2}{*}{$4,001-7,000$} & 0.743 & 1.166 & 1.125 & 0.249 \\
\hline & $(0.725)$ & $(0.709)$ & $(0.799)$ & $(0.725)$ \\
\hline \multirow[t]{2}{*}{ Above 7,000} & 0.379 & -0.030 & 0.062 & 0.679 \\
\hline & $(1.005)$ & $(1.029)$ & $(1.314)$ & $(0.995)$ \\
\hline \multirow[t]{2}{*}{ Real estate owner } & 0.038 & 0.092 & 0.226 & -0.011 \\
\hline & $(0.400)$ & $(0.410)$ & $(0.468)$ & $(0.424)$ \\
\hline \multirow[t]{2}{*}{ Bitcoin buyer } & $3.437 * * *$ & $2.852 * * *$ & $3.131 * * *$ & $3.813 * * *$ \\
\hline & $(0.638)$ & $(0.526)$ & $(0.614)$ & $(0.601)$ \\
\hline \multirow[t]{2}{*}{ Best estimate public acceptance } & 0.084 & 0.295 & 0.497 & 0.212 \\
\hline & $(0.376)$ & $(0.354)$ & $(0.451)$ & $(0.418)$ \\
\hline \multirow[t]{2}{*}{ Overestimate public acceptance } & -0.501 & -0.149 & $1.192 *$ & -0.005 \\
\hline & $(0.657)$ & $(0.609)$ & $(0.688)$ & $(0.697)$ \\
\hline Best estimate $\mathrm{CO}_{2}$ emissions & 0.421 & -0.461 & 0.018 & 0.008 \\
\hline & $(0.392)$ & $(0.373)$ & $(0.442)$ & $(0.442)$ \\
\hline Overestimate $\mathrm{CO}_{2}$ emissions & 0.288 & -0.365 & 0.211 & 0.154 \\
\hline & $(0.427)$ & $(0.384)$ & $(0.492)$ & $(0.444)$ \\
\hline Best estimate value stolen & -0.120 & -0.084 & -0.341 & -0.168 \\
\hline & $(0.564)$ & $(0.480)$ & $(0.679)$ & $(0.602)$ \\
\hline Overestimate value stolen & -0.536 & 0.201 & 0.017 & -0.091 \\
\hline & $(0.586)$ & $(0.518)$ & $(0.689)$ & $(0.608)$ \\
\hline Constant & $3.921^{*}$ & $8.637 * * *$ & 0.115 & 2.743 \\
\hline & $(2.028)$ & $(2.364)$ & (2.904) & $(2.298)$ \\
\hline Observations & 167 & 167 & 157 & 166 \\
\hline R squared & 0.383 & 0.425 & 0.354 & 0.445 \\
\hline Adjusted R squared & 0.284 & 0.333 & 0.242 & 0.355 \\
\hline $\begin{array}{l}\text { ation stage, we placed a } 33.3 \% \text { band around ea } \\
\text { restimates" group, and answers below this ba } \\
\text { width, but the results did not change significan }\end{array}$ & $\overline{\text { bust standard errors fo }}$ & icipants in the highest & $\begin{array}{l}\text { nemployment, incom } \\
\text { ncome below } € 1,000 \text {. } \\
\text { est estimates" group. }\end{array}$ & $\begin{array}{l}\text { ibution. Each column shows } \\
\text { e from a linear regression of } \\
\text { licating the subgroup consider } \\
\text { ategories), real estate ownersh } \\
\text { tegorize the answers given in } \\
\text { ers above this band belong to } \\
\text { e also experimented with a } 5\end{array}$ \\
\hline
\end{tabular}


Table A.18. Regression Table for Underestimates Public Acceptance Sample

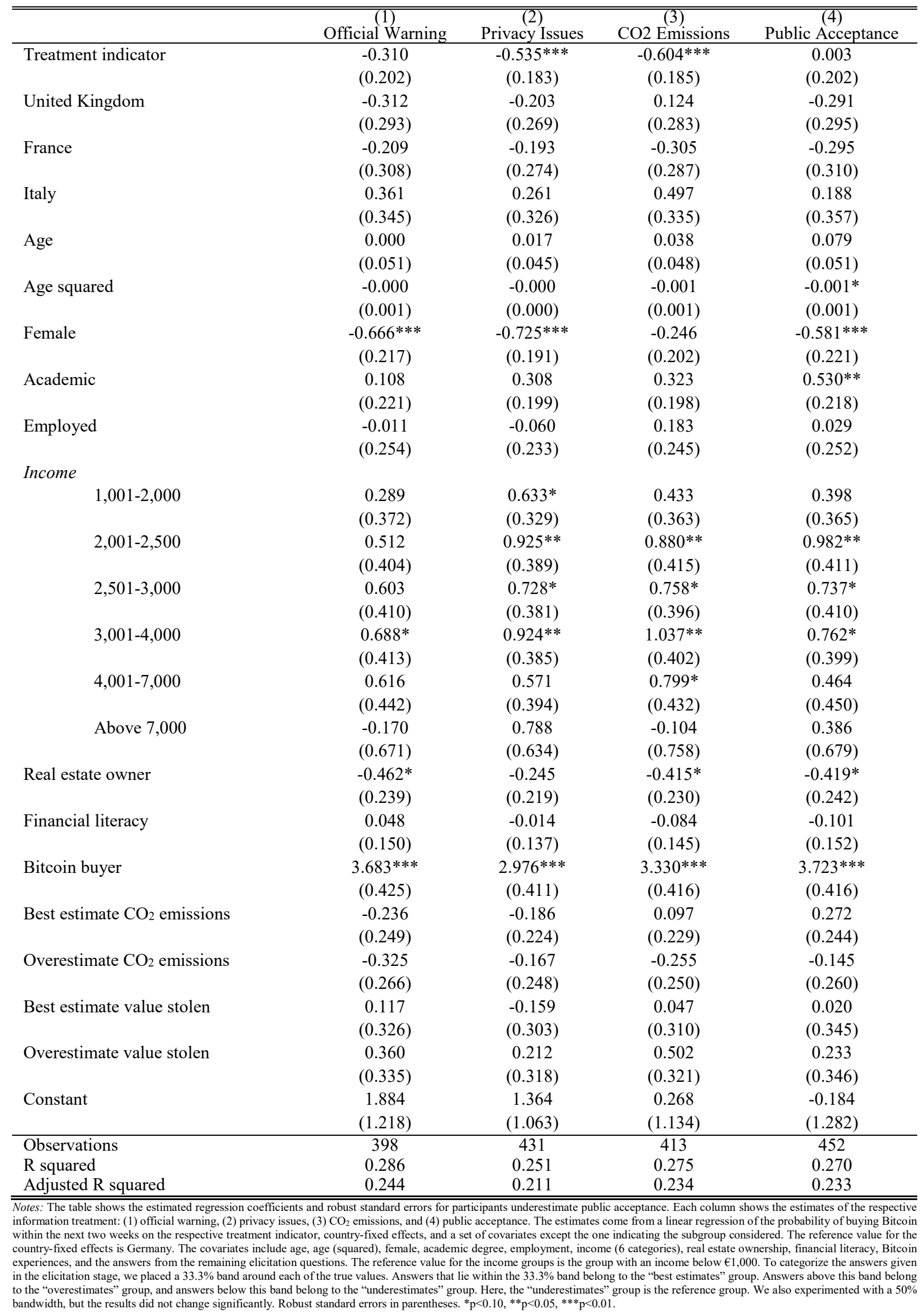


Table A.19. Regression Table for Best Estimates Public Acceptance Sample

\begin{tabular}{|c|c|c|c|c|}
\hline & $\begin{array}{c}\text { (1) } \\
\text { Official Warning }\end{array}$ & $\begin{array}{c}\text { (2) } \\
\text { Privacy Issues }\end{array}$ & $\begin{array}{c}(3) \\
\mathrm{CO} 2 \text { Emissions }\end{array}$ & $\begin{array}{c}\text { (4) } \\
\text { Public Acceptance }\end{array}$ \\
\hline \multirow[t]{2}{*}{ Treatment indicator } & -0.321 & -0.279 & 0.175 & 0.410 \\
\hline & $(0.267)$ & $(0.300)$ & $(0.327)$ & $(0.302)$ \\
\hline \multirow[t]{2}{*}{ United Kingdom } & $-0.675^{*}$ & $-1.010 * *$ & -0.745 & -0.536 \\
\hline & $(0.408)$ & $(0.437)$ & $(0.534)$ & $(0.442)$ \\
\hline \multirow[t]{2}{*}{ France } & -0.620 & -0.695 & -0.314 & -0.336 \\
\hline & $(0.409)$ & $(0.474)$ & $(0.526)$ & $(0.426)$ \\
\hline \multirow[t]{2}{*}{ Italy } & -0.190 & $-0.816^{*}$ & -0.145 & 0.163 \\
\hline & $(0.417)$ & $(0.446)$ & $(0.541)$ & $(0.460)$ \\
\hline \multirow[t]{2}{*}{ Age } & 0.007 & 0.017 & -0.045 & 0.007 \\
\hline & $(0.060)$ & $(0.070)$ & $(0.075)$ & $(0.065)$ \\
\hline \multirow[t]{2}{*}{ Age squared } & -0.000 & -0.000 & 0.000 & -0.000 \\
\hline & $(0.001)$ & $(0.001)$ & $(0.001)$ & $(0.001)$ \\
\hline \multirow[t]{2}{*}{ Female } & -0.445 & -0.131 & $-1.107 * * *$ & -0.285 \\
\hline & $(0.291)$ & $(0.311)$ & $(0.350)$ & $(0.321)$ \\
\hline \multirow[t]{2}{*}{ Academic } & -0.099 & 0.298 & 0.413 & 0.121 \\
\hline & $(0.301)$ & $(0.329)$ & $(0.386)$ & $(0.353)$ \\
\hline \multirow[t]{2}{*}{ Employed } & $0.759 * *$ & 0.461 & 0.701 & $0.662^{*}$ \\
\hline & $(0.356)$ & $(0.371)$ & $(0.439)$ & $(0.382)$ \\
\hline \multicolumn{5}{|l|}{ Income } \\
\hline \multirow[t]{2}{*}{$1,001-2,000$} & 0.170 & -0.061 & 0.280 & -0.036 \\
\hline & $(0.438)$ & $(0.514)$ & $(0.595)$ & $(0.500)$ \\
\hline \multirow[t]{2}{*}{$2,001-2,500$} & -0.131 & 0.443 & 0.068 & $1.050^{*}$ \\
\hline & $(0.501)$ & $(0.600)$ & $(0.663)$ & $(0.566)$ \\
\hline \multirow[t]{2}{*}{$2,501-3,000$} & 0.629 & 0.880 & 0.871 & $1.168^{*}$ \\
\hline & $(0.575)$ & $(0.592)$ & $(0.713)$ & $(0.595)$ \\
\hline \multirow[t]{2}{*}{$3,001-4,000$} & -0.471 & 0.064 & 0.461 & 0.824 \\
\hline & $(0.533)$ & $(0.595)$ & $(0.725)$ & $(0.586)$ \\
\hline \multirow[t]{2}{*}{$4,001-7,000$} & -0.018 & 0.671 & 0.358 & $1.790 * * *$ \\
\hline & $(0.576)$ & $(0.701)$ & $(0.775)$ & $(0.647)$ \\
\hline \multirow[t]{2}{*}{ Above 7,000} & -1.327 & -0.442 & -0.366 & 0.180 \\
\hline & $(0.863)$ & $(1.145)$ & $(1.123)$ & (1.049) \\
\hline \multirow[t]{2}{*}{ Real estate owner } & 0.465 & -0.074 & 0.160 & -0.324 \\
\hline & $(0.307)$ & $(0.353)$ & $(0.400)$ & $(0.340)$ \\
\hline \multirow[t]{2}{*}{ Financial literacy } & $-0.417 * *$ & $-0.426^{*}$ & $-0.644 * *$ & -0.322 \\
\hline & $(0.206)$ & $(0.229)$ & $(0.266)$ & $(0.220)$ \\
\hline \multirow[t]{2}{*}{ Bitcoin buyer } & $3.421 * * *$ & $3.200 * * *$ & $2.140 * * *$ & $3.398 * * *$ \\
\hline & $(0.472)$ & $(0.493)$ & $(0.542)$ & $(0.436)$ \\
\hline \multirow[t]{2}{*}{ Best estimate $\mathrm{CO}_{2}$ emissions } & 0.268 & -0.493 & 0.133 & 0.013 \\
\hline & $(0.398)$ & $(0.428)$ & $(0.491)$ & $(0.421)$ \\
\hline \multirow[t]{2}{*}{ Overestimate $\mathrm{CO}_{2}$ emissions } & 0.252 & -0.695 & 0.126 & -0.342 \\
\hline & $(0.407)$ & $(0.427)$ & $(0.498)$ & $(0.439)$ \\
\hline Best estimate value stolen & 0.085 & 0.479 & 0.598 & 0.432 \\
\hline & $(0.664)$ & $(0.678)$ & $(0.989)$ & $(0.689)$ \\
\hline Overestimate value stolen & -0.175 & 0.628 & 0.705 & 0.360 \\
\hline & $(0.666)$ & $(0.680)$ & $(1.002)$ & $(0.690)$ \\
\hline Constant & $2.506^{*}$ & $2.838^{*}$ & $3.723 * *$ & 1.736 \\
\hline & $(1.482)$ & $(1.687)$ & $(1.872)$ & $(1.619)$ \\
\hline Observations & 242 & 243 & 225 & 258 \\
\hline R squared & 0.355 & 0.314 & 0.278 & 0.402 \\
\hline Adjusted R squared & 0.290 & 0.246 & 0.200 & 0.346 \\
\hline $\begin{array}{l}\text { ial literacy, Bitcoin experiences, and } \\
\text { rize the answers given in the elicita } \\
\text { rs above this band belong to the " } \\
\text { o experimented with a } 50 \% \text { bandwi }\end{array}$ & $\begin{array}{l}\text { inswers below thy } \\
\text { change significa }\end{array}$ & $\begin{array}{l}\text { to the "underestim } \\
\text { ndard errors in par }\end{array}$ & $\begin{array}{l}\text { es except the one } \\
\text { employment, income } \\
\text { ome groups is the gro } \\
\text { ithin the } 33.3 \% \text { band } \\
\text { p. Here, the "underest } \\
* \text { p }<0.10,{ }^{* *} p<0.05 \text {, }\end{array}$ & $\begin{array}{l}\text { Each column shows the estima } \\
\text { near regression of the probabil } \\
\text { g the subgroup considered. } \\
\text { ttegories), real estate ownersh } \\
\text { ith an income below } € 1,000 \text {. } \\
\text { ng to the "best estimates" gro } \\
\text { es" group is the reference gro }\end{array}$ \\
\hline
\end{tabular}


Table A.20. Regression Table for Overestimates Public Acceptance Sample

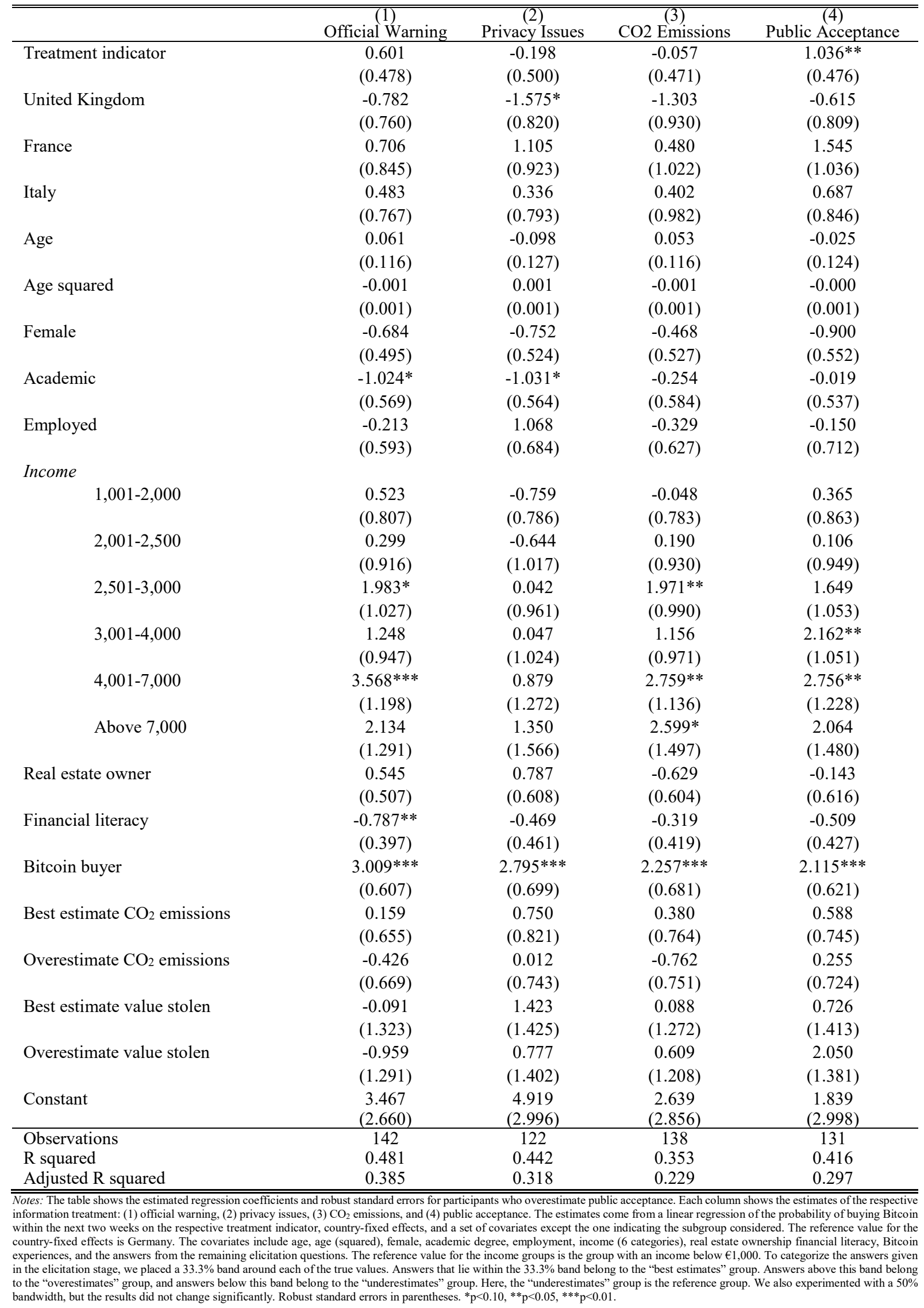


Table A.21. Regression Table for Underestimates $\mathrm{CO}_{2}$ Emissions Sample

\begin{tabular}{|c|c|c|c|c|}
\hline & $\begin{array}{c}(1) \\
\text { Official Warning }\end{array}$ & $\begin{array}{c}(2) \\
\text { Privacy Issues }\end{array}$ & $\begin{array}{c}\mathrm{CO} 2 \text { Emissions } \\
\mathrm{CO}\end{array}$ & $\begin{array}{c}\text { Public Acceptance } \\
\text { Pac }\end{array}$ \\
\hline \multirow[t]{2}{*}{ Treatment indicator } & -0.228 & $-0.548 * *$ & $-0.633^{* *}$ & -0.194 \\
\hline & $(0.274)$ & $(0.241)$ & $(0.246)$ & $(0.263)$ \\
\hline \multirow[t]{2}{*}{ United Kingdom } & $-0.697 *$ & -0.102 & -0.340 & -0.409 \\
\hline & $(0.378)$ & $(0.343)$ & $(0.366)$ & $(0.364)$ \\
\hline \multirow[t]{2}{*}{ France } & -0.605 & -0.295 & -0.243 & -0.642 \\
\hline & $(0.439)$ & $(0.374)$ & $(0.403)$ & $(0.434)$ \\
\hline \multirow[t]{2}{*}{ Italy } & -0.004 & 0.038 & 0.139 & -0.321 \\
\hline & $(0.459)$ & $(0.412)$ & $(0.446)$ & $(0.444)$ \\
\hline \multirow[t]{2}{*}{ Age } & 0.042 & 0.017 & 0.007 & 0.061 \\
\hline & $(0.069)$ & $(0.062)$ & $(0.068)$ & $(0.072)$ \\
\hline \multirow[t]{2}{*}{ Age squared } & -0.001 & -0.001 & -0.000 & -0.001 \\
\hline & $(0.001)$ & $(0.001)$ & $(0.001)$ & $(0.001)$ \\
\hline \multirow[t]{2}{*}{ Female } & $-0.578 * *$ & $-0.495 * *$ & 0.015 & -0.301 \\
\hline & $(0.282)$ & $(0.249)$ & $(0.271)$ & $(0.297)$ \\
\hline \multirow[t]{2}{*}{ Academic } & 0.051 & 0.025 & $0.544 * *$ & $0.475^{*}$ \\
\hline & $(0.291)$ & $(0.261)$ & $(0.273)$ & $(0.286)$ \\
\hline \multirow[t]{2}{*}{ Employed } & -0.326 & -0.019 & $0.581 *$ & -0.038 \\
\hline & $(0.327)$ & $(0.295)$ & $(0.328)$ & $(0.335)$ \\
\hline \multicolumn{5}{|l|}{ Income } \\
\hline \multirow[t]{2}{*}{$1,001-2,000$} & 0.474 & $0.786^{*}$ & 0.600 & 0.664 \\
\hline & $(0.459)$ & $(0.423)$ & $(0.473)$ & $(0.441)$ \\
\hline \multirow[t]{2}{*}{$2,001-2,500$} & 0.747 & $1.275^{* *}$ & 0.639 & $1.249 * *$ \\
\hline & $(0.522)$ & $(0.507)$ & $(0.535)$ & $(0.513)$ \\
\hline \multirow[t]{2}{*}{$2,501-3,000$} & 0.689 & $1.258 * *$ & $1.021^{*}$ & $1.449 * * *$ \\
\hline & $(0.508)$ & $(0.496)$ & $(0.535)$ & $(0.511)$ \\
\hline \multirow[t]{2}{*}{$3,001-4,000$} & $1.158 * *$ & $1.128 * *$ & 0.754 & $1.546^{* * *}$ \\
\hline & $(0.544)$ & $(0.502)$ & $(0.532)$ & $(0.512)$ \\
\hline \multirow[t]{2}{*}{$4,001-7,000$} & 0.586 & 0.783 & 0.493 & 0.874 \\
\hline & $(0.562)$ & $(0.527)$ & $(0.556)$ & $(0.543)$ \\
\hline \multirow[t]{2}{*}{ Above 7,000} & 0.384 & $1.426^{*}$ & -0.404 & 0.557 \\
\hline & $(0.779)$ & $(0.753)$ & $(0.960)$ & $(0.941)$ \\
\hline \multirow[t]{2}{*}{ Real estate owner } & -0.065 & -0.343 & -0.147 & -0.392 \\
\hline & $(0.314)$ & $(0.304)$ & $(0.317)$ & $(0.322)$ \\
\hline \multirow[t]{2}{*}{ Financial literacy } & -0.153 & 0.064 & -0.042 & -0.143 \\
\hline & $(0.199)$ & $(0.180)$ & $(0.188)$ & $(0.197)$ \\
\hline \multirow[t]{2}{*}{ Bitcoin buyer } & $4.169 * * *$ & $3.802 * * *$ & $3.139 * * *$ & $3.671 * * *$ \\
\hline & $(0.485)$ & $(0.494)$ & $(0.476)$ & $(0.509)$ \\
\hline \multirow[t]{2}{*}{ Best estimate public acceptance } & 0.259 & $0.648 * *$ & $0.781 * *$ & $0.921 * * *$ \\
\hline & $(0.358)$ & $(0.310)$ & $(0.338)$ & $(0.343)$ \\
\hline \multirow[t]{2}{*}{ Overestimate public acceptance } & $1.536^{* * *}$ & 0.344 & $1.209^{* *}$ & 0.557 \\
\hline & $(0.459)$ & $(0.461)$ & $(0.475)$ & $(0.506)$ \\
\hline Best estimate value stolen & -0.130 & -0.153 & -0.093 & -0.397 \\
\hline & $(0.358)$ & $(0.310)$ & $(0.343)$ & $(0.375)$ \\
\hline Overestimate value stolen & -0.020 & 0.158 & 0.589 & -0.054 \\
\hline & $(0.374)$ & $(0.339)$ & $(0.359)$ & $(0.382)$ \\
\hline Constant & 1.831 & 1.310 & 0.577 & 0.747 \\
\hline & $(1.590)$ & $(1.472)$ & $(1.535)$ & $(1.769)$ \\
\hline Observations & 269 & 291 & 278 & 288 \\
\hline R squared & 0.400 & 0.359 & 0.344 & 0.342 \\
\hline Adjusted R squared & 0.347 & 0.306 & 0.287 & 0.288 \\
\hline $\begin{array}{l}\text { otes: The table shows the estimated } \\
\text { timates of the respective informatio } \\
\text { robability of buying Bitcoin within th } \\
\text { he reference value for the country-fi } \\
\text { nancial literacy, Bitcoin experiences }\end{array}$ & eatment & the "underesti & $\begin{array}{l}\text { emissions from Bit } \\
\text { tance. The estimate } \\
\text { ariates except the or } \\
\text { mployment, income } \\
\text { ne groups is the gro } \\
\text { hin the } 33.3 \% \text { band } \\
\text { Here, the "underes } \\
\text { He } 10 \text { ** }{ }^{* *}<0.05 *\end{array}$ & $\begin{array}{l}\text { mining. Each column shows } \\
\text { e from a linear regression of } \\
\text { icating the subgroup consider } \\
\text { ategories), real estate ownersh } \\
\text { ith an income below } € 1,000 \text {. } \\
\text { g to the "best estimates" gro } \\
\text { s" group is the reference gro } \\
\end{array}$ \\
\hline
\end{tabular}


Table A.22. Regression Table for Best Estimates $\mathrm{CO}_{2}$ Emissions Sample

\begin{tabular}{|c|c|c|c|c|}
\hline & $\begin{array}{c}\text { (1) } \\
\text { Official Warning }\end{array}$ & $\begin{array}{c}\text { (2) } \\
\text { Privacy Issues }\end{array}$ & $\begin{array}{c}(3) \\
\mathrm{CO} 2 \text { Emissions }\end{array}$ & $\begin{array}{c}\text { (4) } \\
\text { Public Acceptance }\end{array}$ \\
\hline \multirow[t]{2}{*}{ Treatment indicator } & -0.308 & $-0.524 *$ & -0.042 & $0.571^{*}$ \\
\hline & $(0.259)$ & $(0.286)$ & $(0.291)$ & $(0.292)$ \\
\hline \multirow[t]{2}{*}{ United Kingdom } & -0.589 & $-1.112 * * *$ & -0.704 & -0.434 \\
\hline & $(0.362)$ & $(0.406)$ & $(0.446)$ & $(0.422)$ \\
\hline \multirow[t]{2}{*}{ France } & -0.348 & -0.029 & -0.503 & 0.127 \\
\hline & $(0.389)$ & $(0.428)$ & $(0.461)$ & $(0.426)$ \\
\hline \multirow[t]{2}{*}{ Italy } & 0.070 & -0.093 & 0.237 & 0.572 \\
\hline & $(0.439)$ & $(0.450)$ & $(0.493)$ & $(0.468)$ \\
\hline \multirow[t]{2}{*}{ Age } & 0.065 & -0.019 & 0.063 & 0.004 \\
\hline & $(0.062)$ & $(0.070)$ & $(0.071)$ & $(0.069)$ \\
\hline \multirow[t]{2}{*}{ Age squared } & -0.001 & 0.000 & -0.001 & -0.000 \\
\hline & $(0.001)$ & $(0.001)$ & $(0.001)$ & $(0.001)$ \\
\hline \multirow[t]{2}{*}{ Female } & -0.384 & -0.266 & $-0.789 * *$ & $-0.819 * * *$ \\
\hline & $(0.280)$ & $(0.302)$ & $(0.311)$ & $(0.312)$ \\
\hline \multirow[t]{2}{*}{ Academic } & $-0.558^{*}$ & -0.156 & -0.314 & 0.007 \\
\hline & $(0.290)$ & $(0.315)$ & $(0.320)$ & $(0.336)$ \\
\hline \multirow[t]{2}{*}{ Employed } & 0.458 & 0.412 & 0.355 & 0.562 \\
\hline & $(0.343)$ & $(0.372)$ & $(0.395)$ & $(0.397)$ \\
\hline \multicolumn{5}{|l|}{ Income } \\
\hline \multirow[t]{2}{*}{$1,001-2,000$} & -0.310 & -0.499 & 0.092 & -0.171 \\
\hline & $(0.479)$ & $(0.493)$ & $(0.532)$ & $(0.540)$ \\
\hline \multirow[t]{2}{*}{$2,001-2,500$} & -0.498 & -0.089 & -0.029 & 0.438 \\
\hline & $(0.535)$ & $(0.590)$ & $(0.619)$ & $(0.587)$ \\
\hline \multirow[t]{2}{*}{$2,501-3,000$} & $1.023^{*}$ & 0.567 & 0.960 & 0.831 \\
\hline & $(0.564)$ & $(0.558)$ & $(0.608)$ & $(0.624)$ \\
\hline \multirow[t]{2}{*}{$3,001-4,000$} & -0.523 & -0.169 & 0.557 & 0.424 \\
\hline & $(0.540)$ & $(0.583)$ & $(0.623)$ & $(0.609)$ \\
\hline \multirow[t]{2}{*}{$4,001-7,000$} & 0.594 & 0.445 & 0.580 & $1.207^{*}$ \\
\hline & $(0.587)$ & $(0.638)$ & $(0.677)$ & $(0.698)$ \\
\hline \multirow[t]{2}{*}{ Above 7,000} & -0.671 & 0.824 & 1.331 & 0.359 \\
\hline & (1.044) & $(1.421)$ & $(1.176)$ & (1.009) \\
\hline \multirow[t]{2}{*}{ Real estate owner } & -0.035 & -0.045 & -0.049 & -0.198 \\
\hline & $(0.295)$ & $(0.318)$ & $(0.346)$ & $(0.333)$ \\
\hline \multirow[t]{2}{*}{ Financial literacy } & -0.156 & -0.327 & $-0.477 * *$ & $-0.522 * *$ \\
\hline & $(0.206)$ & $(0.236)$ & $(0.238)$ & $(0.227)$ \\
\hline \multirow[t]{2}{*}{ Bitcoin buyer } & $2.874 * * *$ & $1.912 * * *$ & $2.472 * * *$ & $2.963 * * *$ \\
\hline & $(0.420)$ & $(0.525)$ & $(0.497)$ & $(0.458)$ \\
\hline \multirow[t]{2}{*}{ Best estimate public acceptance } & $0.684 * *$ & $0.833 * *$ & $0.664 *$ & $0.702 * *$ \\
\hline & $(0.302)$ & $(0.333)$ & $(0.338)$ & $(0.335)$ \\
\hline \multirow[t]{2}{*}{ Overestimate public acceptance } & $2.007 * * *$ & $1.686^{* * *}$ & $1.570 * * *$ & $1.455 * * *$ \\
\hline & $(0.379)$ & $(0.447)$ & $(0.419)$ & $(0.444)$ \\
\hline Best estimate value stolen & 1.052 & 0.657 & 0.488 & 1.192 \\
\hline & $(0.883)$ & $(1.043)$ & $(1.092)$ & $(0.818)$ \\
\hline Overestimate value stolen & 0.715 & 1.090 & 1.274 & $1.374^{*}$ \\
\hline & $(0.885)$ & $(1.048)$ & $(1.078)$ & $(0.811)$ \\
\hline Constant & 0.220 & 2.108 & 0.625 & 0.769 \\
\hline & $(1.667)$ & $(1.859)$ & $(1.995)$ & $(1.830)$ \\
\hline Observations & 271 & 264 & 263 & 292 \\
\hline R squared & 0.431 & 0.310 & 0.376 & 0.378 \\
\hline Adjusted R squared & 0.380 & 0.247 & 0.319 & 0.327 \\
\hline $\begin{array}{l}\text { To categorize the answers give } \\
\text { Answers above this band belons } \\
\text { We also experimented with a } 50\end{array}$ & $\begin{array}{l}\text { aced a } 33.3 \% \text { band ar } \\
0 \text {, and answers below } \\
\text { did not change signifi }\end{array}$ & $\begin{array}{l}\text { of the true values } \\
\text { elong to the "uns }\end{array}$ & $\begin{array}{l}\text { a set of covariates ex } \\
\text { emic degree, employm } \\
\text { for the income group } \\
\text { that lie within the } 33.3^{\circ} \\
\text { s" group. Here, the "u }\end{array}$ & $\begin{array}{l}\text { Bitcoin mining. Each colu } \\
\text { tes come from a linear regress } \\
\text { the one indicating the subgr } \\
\text { income ( } 6 \text { categories), real es } \\
\text { the group with an income bel } \\
\text { nd belong to the "best estimat } \\
\text { estimates" group is the refere } \\
* * * \text { p }<0.01 \text {. }\end{array}$ \\
\hline
\end{tabular}


Table A.23. Regression Table for Overestimates $\mathrm{CO}_{2}$ Emissions Sample

\begin{tabular}{|c|c|c|c|c|}
\hline & $\begin{array}{c}\text { Official Warning } \\
\text { O(1) }\end{array}$ & $\begin{array}{c}(2) \\
\text { Privacy Issues }\end{array}$ & $\begin{array}{c}\text { (3) } \\
\mathrm{CO} 2 \text { Emissions }\end{array}$ & $\begin{array}{c}\text { (4) } \\
\text { Public Acceptance }\end{array}$ \\
\hline \multirow[t]{2}{*}{ Treatment indicator } & -0.122 & -0.347 & -0.088 & $0.562 *$ \\
\hline & $(0.302)$ & $(0.292)$ & $(0.308)$ & $(0.302)$ \\
\hline \multirow[t]{2}{*}{ United Kingdom } & 0.150 & $-0.871 *$ & 0.231 & -0.388 \\
\hline & $(0.515)$ & $(0.482)$ & $(0.546)$ & $(0.498)$ \\
\hline \multirow[t]{2}{*}{ France } & 0.147 & -0.687 & 0.015 & -0.172 \\
\hline & $(0.454)$ & $(0.454)$ & $(0.497)$ & $(0.451)$ \\
\hline \multirow[t]{2}{*}{ Italy } & 0.589 & -0.411 & 0.469 & 0.381 \\
\hline & $(0.449)$ & $(0.471)$ & $(0.507)$ & $(0.490)$ \\
\hline \multirow[t]{2}{*}{ Age } & -0.047 & 0.009 & -0.051 & -0.009 \\
\hline & $(0.066)$ & $(0.068)$ & $(0.069)$ & $(0.064)$ \\
\hline \multirow[t]{2}{*}{ Age squared } & 0.000 & -0.000 & 0.000 & -0.000 \\
\hline & $(0.001)$ & $(0.001)$ & $(0.001)$ & $(0.001)$ \\
\hline \multirow[t]{2}{*}{ Female } & $-1.019 * * *$ & $-0.948 * * *$ & $-0.980 * * *$ & $-0.634 * *$ \\
\hline & $(0.326)$ & $(0.298)$ & $(0.330)$ & $(0.313)$ \\
\hline \multirow[t]{2}{*}{ Academic } & 0.281 & 0.329 & $0.570^{*}$ & 0.417 \\
\hline & $(0.331)$ & $(0.314)$ & $(0.339)$ & $(0.313)$ \\
\hline \multirow[t]{2}{*}{ Employed } & 0.285 & 0.328 & -0.132 & -0.090 \\
\hline & $(0.376)$ & $(0.366)$ & $(0.395)$ & $(0.357)$ \\
\hline \multicolumn{5}{|l|}{ Income } \\
\hline \multirow[t]{2}{*}{$1,001-2,000$} & 0.508 & 0.052 & 0.035 & 0.221 \\
\hline & $(0.517)$ & $(0.505)$ & $(0.535)$ & $(0.504)$ \\
\hline \multirow[t]{2}{*}{$2,001-2,500$} & 0.711 & 0.289 & 0.602 & 0.763 \\
\hline & $(0.584)$ & $(0.589)$ & $(0.599)$ & $(0.572)$ \\
\hline \multirow[t]{2}{*}{$2,501-3,000$} & 0.476 & -0.056 & 0.488 & 0.717 \\
\hline & $(0.674)$ & $(0.588)$ & $(0.623)$ & $(0.605)$ \\
\hline \multirow[t]{2}{*}{$3,001-4,000$} & 0.527 & 0.289 & 0.909 & 0.749 \\
\hline & $(0.610)$ & $(0.574)$ & $(0.647)$ & $(0.575)$ \\
\hline \multirow[t]{2}{*}{$4,001-7,000$} & 0.804 & 0.040 & $1.582 * *$ & $1.648 * *$ \\
\hline & $(0.687)$ & $(0.641)$ & $(0.714)$ & $(0.680)$ \\
\hline \multirow[t]{2}{*}{ Above 7,000} & 0.083 & -0.220 & -0.151 & 0.743 \\
\hline & $(0.884)$ & $(0.959)$ & $(0.964)$ & $(0.927)$ \\
\hline \multirow[t]{2}{*}{ Real estate owner } & 0.016 & 0.251 & -0.287 & -0.281 \\
\hline & $(0.344)$ & $(0.358)$ & $(0.375)$ & $(0.358)$ \\
\hline \multirow[t]{2}{*}{ Financial literacy } & -0.111 & -0.213 & -0.006 & 0.014 \\
\hline & $(0.223)$ & $(0.212)$ & $(0.248)$ & $(0.217)$ \\
\hline \multirow[t]{2}{*}{ Bitcoin buyer } & $3.832 * * *$ & $3.014 * * *$ & $2.436 * * *$ & $3.291 * * *$ \\
\hline & $(0.511)$ & $(0.468)$ & $(0.538)$ & $(0.424)$ \\
\hline \multirow[t]{2}{*}{ Best estimate public acceptance } & $0.674^{*}$ & 0.395 & $1.520^{* * *}$ & $0.899 * * *$ \\
\hline & $(0.356)$ & $(0.346)$ & $(0.372)$ & $(0.342)$ \\
\hline \multirow[t]{2}{*}{ Overestimate public acceptance } & $0.879 * *$ & $0.814^{* *}$ & $1.392 * * *$ & $1.637 * * *$ \\
\hline & $(0.434)$ & $(0.400)$ & $(0.417)$ & $(0.414)$ \\
\hline Best estimate value stolen & 0.913 & -0.399 & 0.243 & 0.184 \\
\hline & $(0.850)$ & $(1.038)$ & $(1.043)$ & $(0.838)$ \\
\hline Overestimate value stolen & 1.003 & -0.253 & 0.070 & 0.503 \\
\hline & $(0.816)$ & $(1.017)$ & $(1.013)$ & $(0.816)$ \\
\hline Constant & 1.429 & 2.796 & 2.091 & 0.687 \\
\hline & $(1.726)$ & $(1.865)$ & $(1.972)$ & $(1.687)$ \\
\hline Observations & 242 & 241 & 235 & 261 \\
\hline R squared & 0.391 & 0.358 & 0.305 & 0.403 \\
\hline Adjusted R squared & 0.330 & 0.293 & 0.232 & 0.347 \\
\hline $\begin{array}{l}\text { otes: The table shows the estimated regressior } \\
\text { timates of the respective information treatmen } \\
\text { robability of buying Bitcoin within the next two } \\
\text { he reference value for the country-fixed effects } \\
\text { nancial literacy, Bitcoin experiences, and the a } \\
\text { ategorize the answers given in the elicitation st } \\
\text { nswers above this band belong to the "overesti } \\
\text { le also experimented with a } 50 \% \text { bandwidth, bu }\end{array}$ & ates include a & $\begin{array}{l}\text {-fixed effects, a } \\
\text { d), female, acad } \\
\text { e reference valu }\end{array}$ & $\begin{array}{l}\text { emissions from Bitc } \\
\text { eptance. The estimates } \\
\text { ovariates except the one } \\
\text {, employment, income } \\
\text { ome groups is the grol } \\
\text { ithin the } 33.3 \% \text { band } t \\
\text { p. Here, the "underesti } \\
* \text { p }<0.10 * \text { p }<0.05 * *\end{array}$ & $\begin{array}{l}\text { mining. Each column shows } \\
\text { e from a linear regression of } \\
\text { icating the subgroup consider } \\
\text { ategories), real estate ownersh } \\
\text { ith an income below } € 1,000 \text {. } \\
\text { g to the "best estimates" gro } \\
\text { s" group is the reference gro } \\
\text { g. gl }\end{array}$ \\
\hline
\end{tabular}


Table A.24. Regression Table for Underestimates Extent of Theft Sample

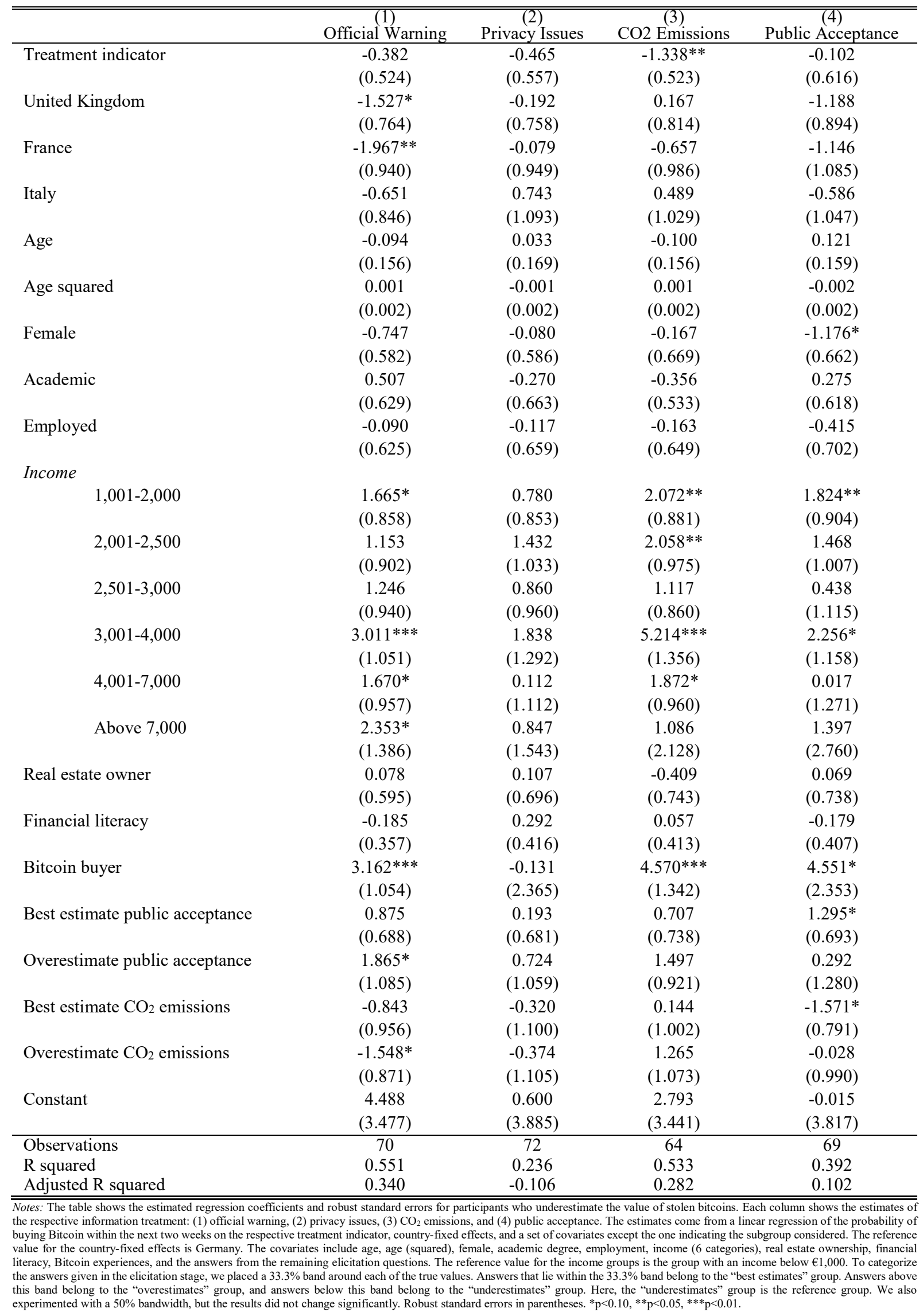


Table A.25. Regression Table for Best Estimates Extent of Theft Sample

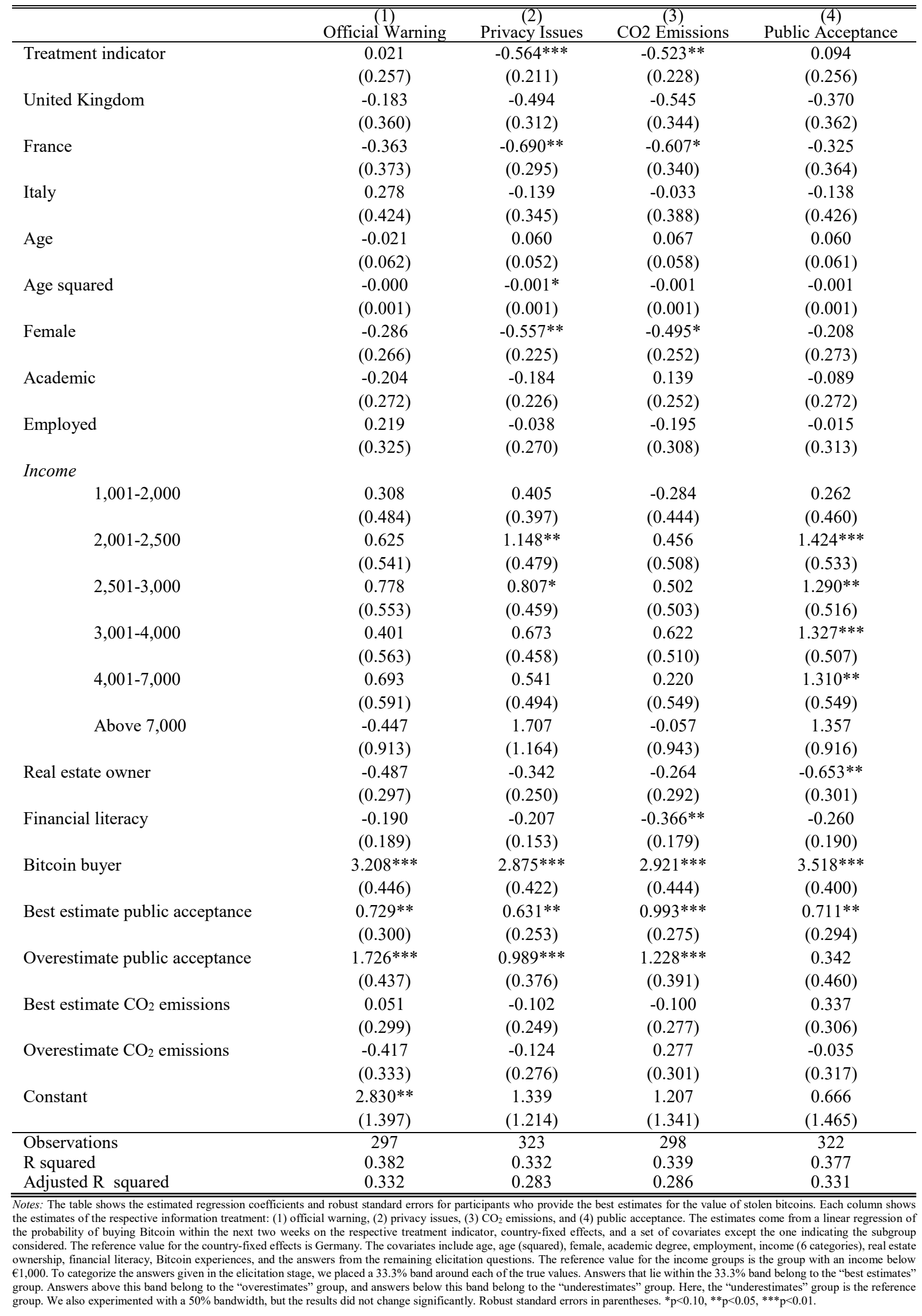


Table A.26. Regression Table for Overestimates Extent of Theft Sample

\begin{tabular}{|c|c|c|c|c|}
\hline & $\begin{array}{c}\text { (1) } \\
\text { Official Warning }\end{array}$ & $\begin{array}{c}(2) \\
\text { Privacy Issues }\end{array}$ & $\begin{array}{c}(3) \\
\mathrm{CO} 2 \text { Emissions } \\
\end{array}$ & $\begin{array}{c}\text { (4) } \\
\text { Public Acceptance }\end{array}$ \\
\hline \multirow[t]{2}{*}{ Treatment indicator } & -0.351 & $-0.398^{*}$ & -0.064 & $0.446^{* *}$ \\
\hline & $(0.217)$ & $(0.241)$ & $(0.242)$ & $(0.225)$ \\
\hline \multirow[t]{2}{*}{ United Kingdom } & -0.486 & -0.531 & -0.063 & -0.201 \\
\hline & $(0.342)$ & $(0.382)$ & $(0.398)$ & $(0.338)$ \\
\hline \multirow[t]{2}{*}{ France } & -0.027 & 0.206 & 0.185 & -0.005 \\
\hline & $(0.355)$ & $(0.409)$ & $(0.409)$ & $(0.358)$ \\
\hline \multirow[t]{2}{*}{ Italy } & 0.159 & 0.050 & 0.563 & 0.586 \\
\hline & $(0.361)$ & $(0.409)$ & $(0.423)$ & $(0.368)$ \\
\hline \multirow[t]{2}{*}{ Age } & 0.026 & -0.029 & -0.014 & -0.027 \\
\hline & $(0.049)$ & $(0.056)$ & $(0.056)$ & $(0.052)$ \\
\hline \multirow[t]{2}{*}{ Age squared } & -0.001 & 0.000 & -0.000 & 0.000 \\
\hline & $(0.001)$ & $(0.001)$ & $(0.001)$ & $(0.001)$ \\
\hline \multirow[t]{2}{*}{ Female } & $-0.975 * * *$ & $-0.641 * *$ & $-0.715 * * *$ & $-0.787 * * *$ \\
\hline & $(0.239)$ & $(0.252)$ & $(0.257)$ & $(0.244)$ \\
\hline \multirow[t]{2}{*}{ Academic } & -0.120 & 0.313 & $0.442 *$ & $0.608^{* *}$ \\
\hline & $(0.252)$ & $(0.268)$ & $(0.267)$ & $(0.253)$ \\
\hline \multirow[t]{2}{*}{ Employed } & 0.109 & 0.433 & 0.315 & 0.275 \\
\hline & $(0.278)$ & $(0.306)$ & $(0.318)$ & $(0.302)$ \\
\hline \multicolumn{5}{|l|}{ Income } \\
\hline \multirow[t]{2}{*}{$1,001-2,000$} & 0.213 & -0.132 & 0.559 & 0.032 \\
\hline & $(0.365)$ & $(0.417)$ & $(0.443)$ & $(0.393)$ \\
\hline \multirow[t]{2}{*}{$2,001-2,500$} & -0.057 & 0.023 & 0.480 & 0.365 \\
\hline & $(0.416)$ & $(0.478)$ & $(0.490)$ & $(0.432)$ \\
\hline \multirow[t]{2}{*}{$2,501-3,000$} & $0.984 * *$ & 0.643 & $1.269^{* *}$ & $0.916^{* *}$ \\
\hline & $(0.455)$ & $(0.470)$ & $(0.507)$ & $(0.464)$ \\
\hline \multirow[t]{2}{*}{$3,001-4,000$} & 0.250 & 0.251 & $0.848^{*}$ & 0.419 \\
\hline & $(0.424)$ & $(0.479)$ & $(0.505)$ & $(0.448)$ \\
\hline \multirow[t]{2}{*}{$4,001-7,000$} & $0.890^{*}$ & 0.453 & $1.389 * *$ & $1.265^{* *}$ \\
\hline & $(0.485)$ & $(0.533)$ & $(0.552)$ & $(0.522)$ \\
\hline \multirow[t]{2}{*}{ Above 7,000} & 0.144 & 0.149 & 0.469 & 0.046 \\
\hline & $(0.674)$ & $(0.753)$ & $(0.800)$ & $(0.694)$ \\
\hline \multirow[t]{2}{*}{ Real estate owner } & 0.340 & -0.026 & -0.187 & -0.143 \\
\hline & $(0.248)$ & $(0.290)$ & $(0.293)$ & $(0.261)$ \\
\hline \multirow[t]{2}{*}{ Financial literacy } & $-0.319 *$ & -0.114 & -0.221 & -0.211 \\
\hline & $(0.167)$ & $(0.197)$ & $(0.190)$ & $(0.175)$ \\
\hline \multirow[t]{2}{*}{ Bitcoin buyer } & $3.416^{* * *}$ & $3.008 * * *$ & $2.302 * * *$ & $2.852 * * *$ \\
\hline & $(0.363)$ & $(0.391)$ & $(0.403)$ & $(0.351)$ \\
\hline \multirow[t]{2}{*}{ Best estimate public acceptance } & 0.413 & $0.704 * *$ & $0.997 * * *$ & $0.765 * * *$ \\
\hline & $(0.266)$ & $(0.291)$ & $(0.299)$ & $(0.273)$ \\
\hline \multirow[t]{2}{*}{ Overestimate public acceptance } & $1.209 * * *$ & $1.223 * * *$ & $1.482 * * *$ & $1.712 * * *$ \\
\hline & $(0.310)$ & $(0.359)$ & $(0.343)$ & $(0.325)$ \\
\hline Best estimate $\mathrm{CO}_{2}$ emissions & -0.051 & 0.033 & 0.171 & 0.429 \\
\hline & $(0.300)$ & $(0.328)$ & $(0.329)$ & $(0.301)$ \\
\hline Overestimate $\mathrm{CO}_{2}$ emissions & -0.160 & -0.516 & $-0.632 *$ & -0.116 \\
\hline & $(0.300)$ & $(0.329)$ & $(0.340)$ & $(0.307)$ \\
\hline Constant & $1.988^{*}$ & $2.727 * *$ & 1.872 & 1.943 \\
\hline & $(1.187)$ & $(1.315)$ & $(1.336)$ & $(1.244)$ \\
\hline Observations & -0.351 & $-0.398 *$ & -0.064 & $0.446^{* *}$ \\
\hline R squared & $(0.217)$ & $(0.241)$ & $(0.242)$ & $(0.225)$ \\
\hline Adjusted R squared & 0.000 & 0.000 & 0.000 & 0.000 \\
\hline $\begin{array}{l}\text { band belong to the "overestimates" group, } \\
\text { rimented with a } 50 \% \text { bandwidth, but the res }\end{array}$ & this band belong to & $\begin{array}{l}\text { value for the inc } \\
\text { wers that lie withi } \\
\text { restimates" group }\end{array}$ & 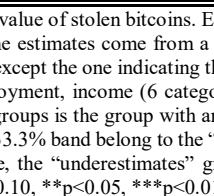 & $\begin{array}{l}\text { lumn shows the estimates of } \\
\text { regression of the probability } \\
\text { group considered. The refere } \\
\text { real estate ownership, finan } \\
\text { me below } € 1,000 \text {. To categor } \\
\text { stimates" group. Answers ab } \\
\text { is the reference group. We a }\end{array}$ \\
\hline
\end{tabular}




\title{
Appendix B: The English Questionnaire
}

\author{
Dear participant,
}

we are conducting a research project on Bitcoin \& Cryptocurrency at the Institute of Economic Policy at the Leibniz University of Hannover.

In the following, we will ask you different questions about this topic. Your personal assessment is important to us.

The survey is completely anonymous. All questions about your person (age, gender, etc.) are for statistical analysis only. We cannot draw any conclusions about your identity.

Thank you very much for supporting our research!

\section{Part A: What is a Bitcoin?}

$\Rightarrow$ Please read the following text carefully!

Bitcoin is the world's leading cryptocurrency - a digital means of payment based on encryption technologies.

Bitcoin works via a decentralized computer network. In contrast to the classic banking system, there is no central authority for transmitting and clearing payments.

Instead, all computers in the network check and approve payments together. At the same time they store all payments. Since the payment data is distributed over all computers in the network, we speak of a distributed database or distributed ledger.

When a payment is initiated, the network traces all previous payments and ensures that the payer has the necessary amount of Bitcoins - i.e. he is solvent.

Since the database is public, all payments are transparent. However, participants do not use their civil names or companies, but encrypted Bitcoin addresses. In this way, Bitcoin prevents direct identification of trading partners.

When a computer has confirmed a certain amount of payments and is the first to solve a complex number puzzle, it receives a Bitcoin as reward. This is how new Bitcoins are created. The amount of newly confirmed payments is a so-called block. Since the distributed database consists of a chain of such blocks, the technology is called blockchain. 


\section{Part B: What do you know about Bitcoin?}

B1. How high do you estimate the proportion of the world's population that could imagine paying with Bitcoin (or any other crypto currency)?

$\Rightarrow$ Please indicate the estimated share in \%!

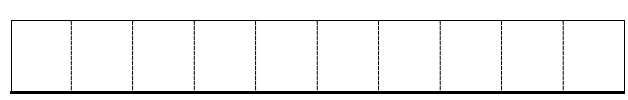

B2. How high do you estimate the annual $\mathrm{CO} 2$ emissions caused by the production of Bitcoins?

By comparison, the entire British economy produces approximately 370 megatons (Mt) annually.

$\Rightarrow$ Please indicate the estimated value in megatons (Mt)!

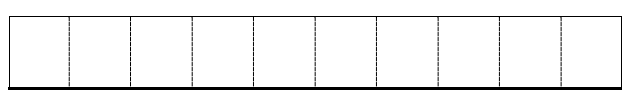

B3. How high do you estimate the market value of Bitcoins stolen worldwide in the first half of 2019?

$\Rightarrow$ Please indicate the estimated value in billion pound sterling (GBP)!

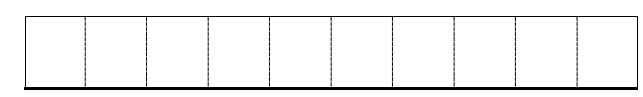




\section{Part C: What is your attitude towards using Bitcoins?}

\section{IMPORTANT NOTE!}

The Corona crisis has caused a push for digitalization in the UK through home office work, web conferencing and the increase in online shopping.

The corona-induced behavioral changes have thus led to a higher general acceptance of Bitcoins. But even before the crisis, Bitcoins were accepted as a means of payment by parts of the population.

In a representative survey conducted in 2019, one quarter (25\%) of respondents indicated that they could imagine paying with Bitcoin (or other cryptocurrencies).

\section{IMPORTANT NOTE!}

The environmental impact of electricity consumption in the production of Bitcoins is criticized. According to a study from 2019, annual CO2 emissions are around 22 megatons of CO2. That is about as much as the annual emissions of the whole of Lebanon.

\section{IMPORTANT NOTE!}

The use of Bitcoins is associated with risks. Bitcoins are purchased on trading platforms and stored in "digital wallets". Both are not regulated in the EU. Therefore, if you buy Bitcoins, you will not benefit from the guarantees and safeguards that apply to regulated financial services.

For example, if a trading platform (or "digital wallet" provider) fails, goes out of business, becomes the victim of a cyber attack or government seizure, EU law does not provide specific legal protection that protects you from losses or guarantees you access to your funds.

In the first half of 2019 alone, for example, over 4 billion US dollars (3.1 billion british pounds) in cryptocurrencies were stolen worldwide.

\section{IMPORTANT NOTE!}

Bitcoins are partly used for online sales of drugs, money laundering and human trafficking. Contrary to popular belief, Bitcoin is not completely anonymous.

You can hide your identity. However, each payment is stored on the public database. Investigators use this information, together with sophisticated analysis techniques, to draw conclusions about how you use Bitcoin and who you are.

\section{C1. How do you assess the following statement?}

Buying Bitcoins within the next 2 months is ...

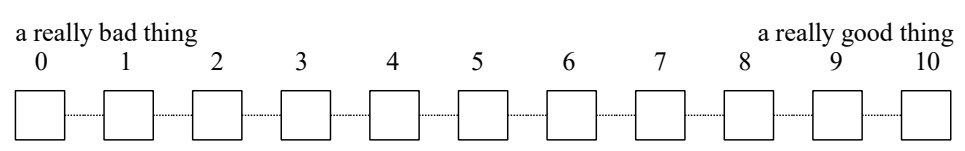

\section{C2. What is the probability that you will buy Bitcoins within the next 2} months?

\section{$\Rightarrow$ Please indicate the probability in $\%$ !}

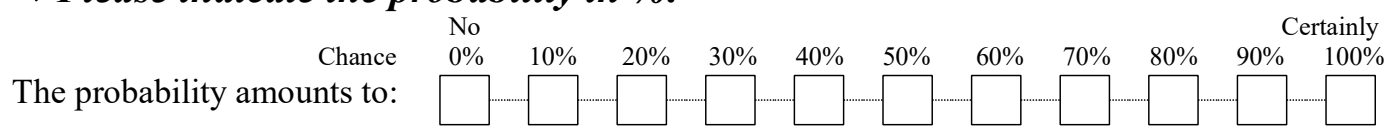




\section{Part D: What are your reasons for or against buying Bitcoins?}

D1. From your point of view, what is the most important reason for buying Bitcoins?

Curiosity

Dissatisfaction with the monetary policy of central banks / search for alternative currencies

As a means of payment for online transactions

Speculation on capital gains

Out of conviction

D2. From your point of view, what is the most important reason against buying Bitcoins?

I simply have no interest in the topic.

I am afraid of a capital loss.

I do not know for which purpose I should use Bitcoin.

It is too complicated to purchase Bitcoin.

I am afraid that my Bitcoins could be stolen.

I do not know how and where I can buy Bitcoins.

The energy consumption in the production of Bitcoins is too high.

\section{Part E: What is your attitude towards using digital central bank currency?}

In response to the problems associated with Bitcoin, various central banks are planning to introduce their own crypto currencies - so-called Central Bank Digital Currency (CBDC).

China is the pioneer in this field. There, the government already pays its officials with digital central bank money. In Europe, Sweden is a pioneer with its E-krona. But the European Central Bank is also considering the introduction of digital central bank money. The first test run with the e-euro recently took place in France.

Digital central bank money is regulated and therefore does not have the same risks as most crypto currencies. Nevertheless, it allows using the advantages of a decentralized database (distributed ledger).

Thanks to this decentralized database, all payments can be traced. This complete transparency makes e.g. payments between machines legally secure, money laundering and tax evasion practically impossible.

Depending on the technical design, digital central bank money could also guarantee the previously missing anonymity in digital payments. Currently, the only fully anonymous means of payment is cash." 
E1. How do you assess the following statement?

Buying Central Bank Digital Currency when it becomes available is ...

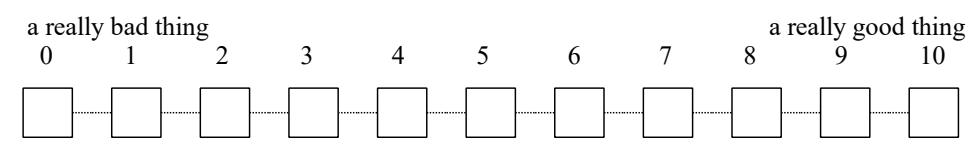

E2. What is the probability that you will buy central bank digital currency when it becomes available?

$\Rightarrow$ Please indicate the probability in $\%$ !

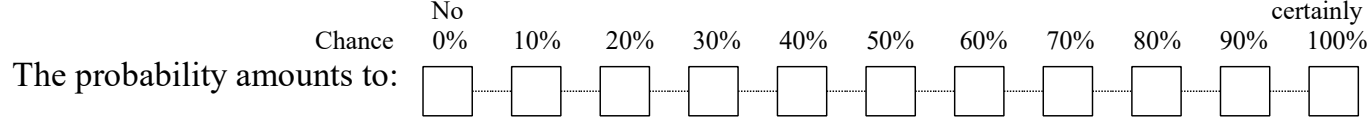

E3. With this question, we want to check if you are reading carefully.

$\Rightarrow$ Please answer with the number 7 !

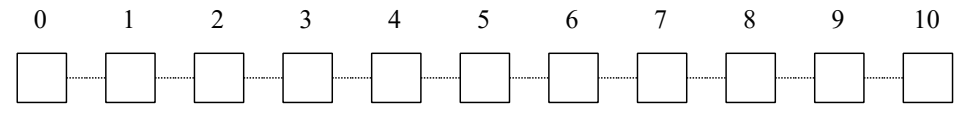




\section{Part F: Information about your person}

$\Rightarrow$ As a reminder, your answers are for statistical analysis only. We cannot draw any conclusions about your identity.

F1. Age

$\Rightarrow$ Please indicate your age in years!

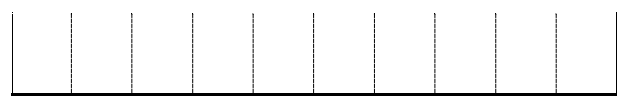

F2. Gender

female
male

F3. What is your highest educational (or vocational) degree?

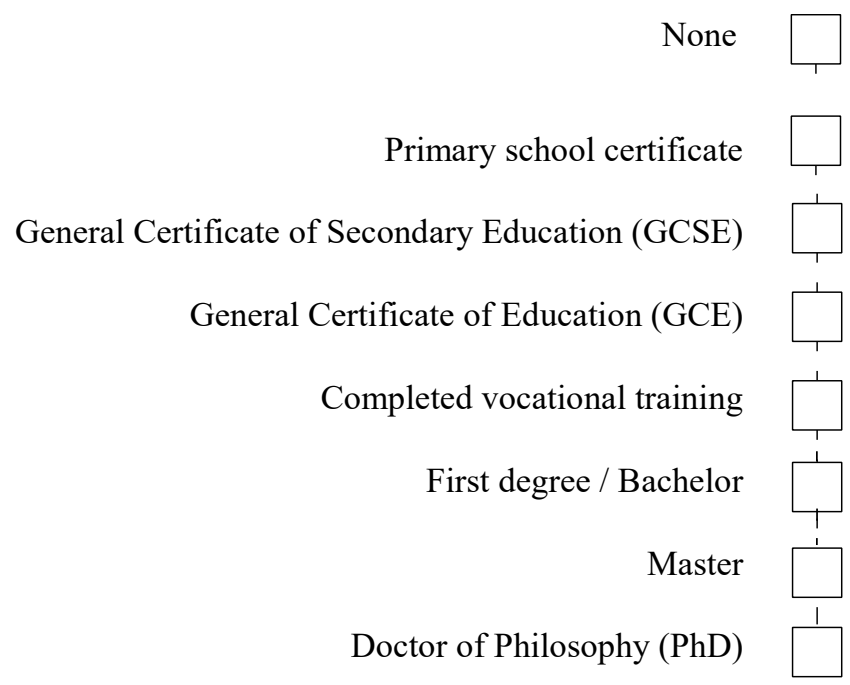

F4. Are you currently in gainful employment?

$\Rightarrow$ What applies to you?

"Out of labour force" means you are neither employed nor unemployed because you have to attend school or are unable to work.

Out of labour force / retired

Unemployed

Part-time

Full-time
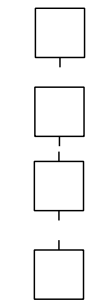
F5. What was the total net income of your household last month?

$\Rightarrow$ This is not a mandatory question. If you don't want to answer it, please just go to the next question!

Net income of household is the sum of net incomes of all household members.

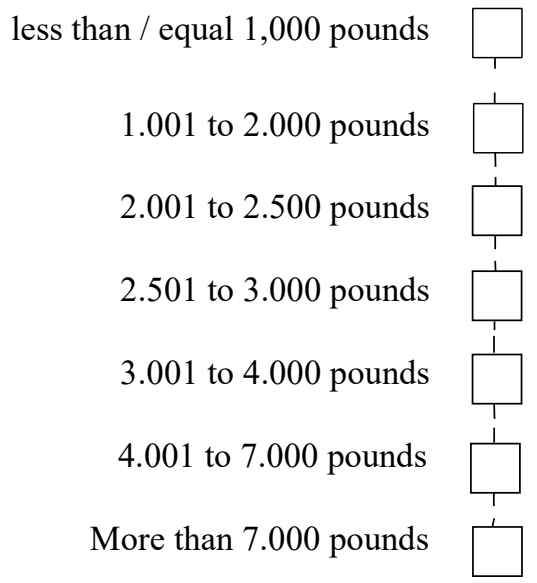

F6. Do you live in your own house / flat or for rent?

Rent

Own house / flat

F7. In which region do you live?

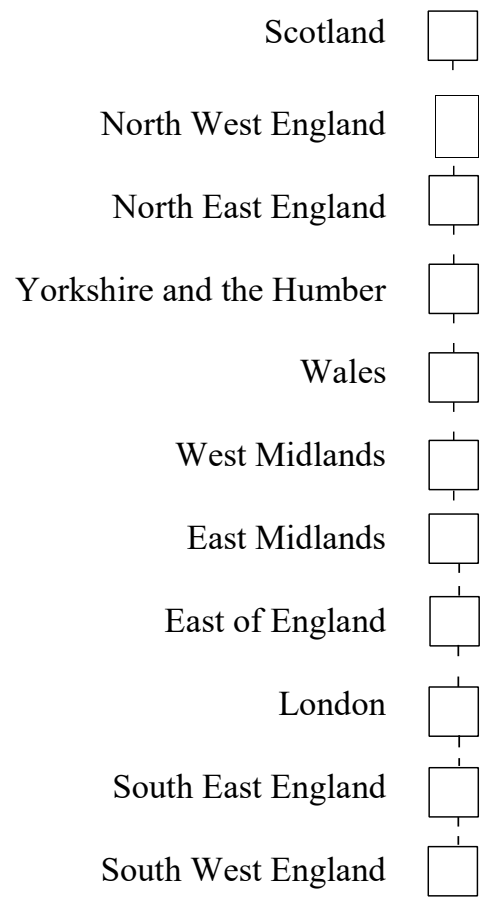




\section{Part G: 4 questions about your financial literacy}

G1. Have you ever bought Bitcoins (or other cryptocurrencies)?

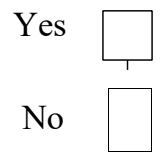

G2. Suppose you had $\mathbf{\$ 1 0 0}$ in a savings account and the interest rate was $2 \%$ per year. After 5 years, how much do you think you would have in the account if you left the money to grow?

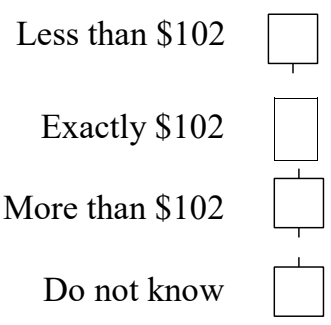

G3. Imagine that the interest rate on your savings account was $1 \%$ per year and inflation was $2 \%$ per year. After 1 year, how much would you be able to buy with the money in this account?

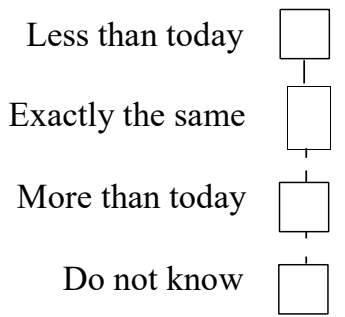

G4. Please tell me whether this statement is true or false. "Buying a single company's stock usually provides a safer return than a stock mutual fund."

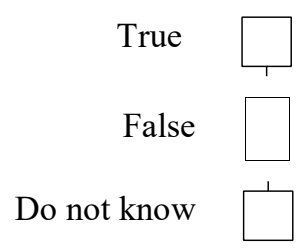


Part H: What is your risk appetite?

H1. Are you generally a risk-taking person or do you try to avoid risks?

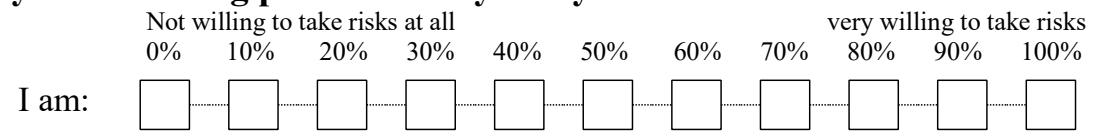

Part I: What is your attitude towards life and the future?

I1. To what extent do you agree with the following statements?

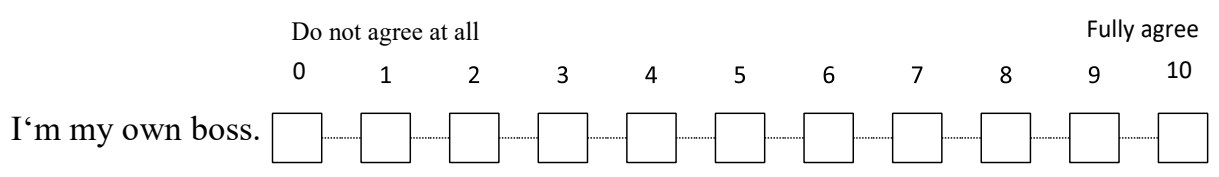

If I work hard, I will succeed.

Whether at work or in my private life:

What I do is mainly determined by others.

Fate often gets in the way of my plans.
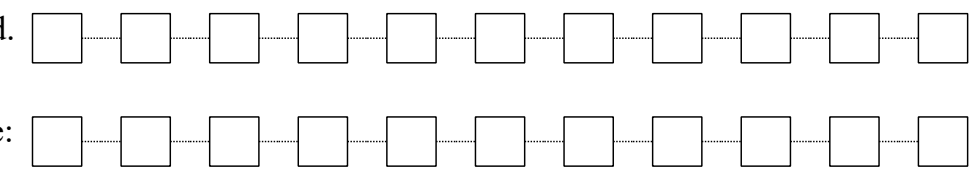

\section{Part J: In light of current events, 3 questions on corona measures}

J1. To what extent do the following statements apply to you personally?

I find the corona measures (keep distance, observe hygiene, face mask) appropriate.

I feel restricted by the corona measures in my daily life.

I abide by the corona measures myself.

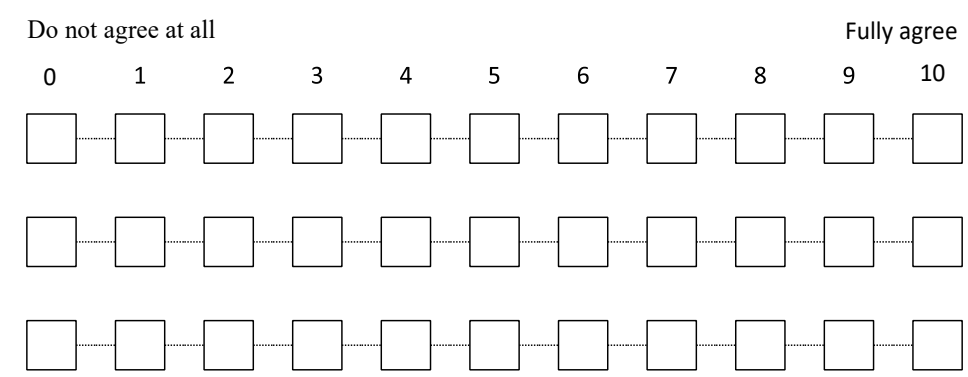




\section{Part K: Finally, 4 questions about your future expectations}

K1. In your opinion, what is the probability (in percent), ...

that your net household income in the next

12 months will be lower than in the previous 12 months. that your net household income in the next 12 months will be higher than in the previous 12 months.

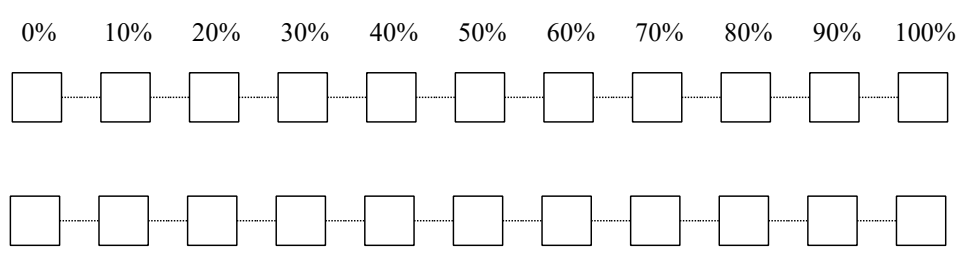

that the infection rate with the coronavirus in 12 months will be lower than today?

that the infection rate with the coronavirus in 12 months will be higher than today?

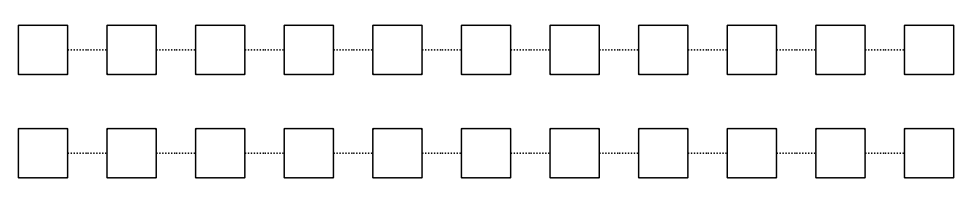

Thank you very much for your participation!

You will now be redirected to the panel provider. 